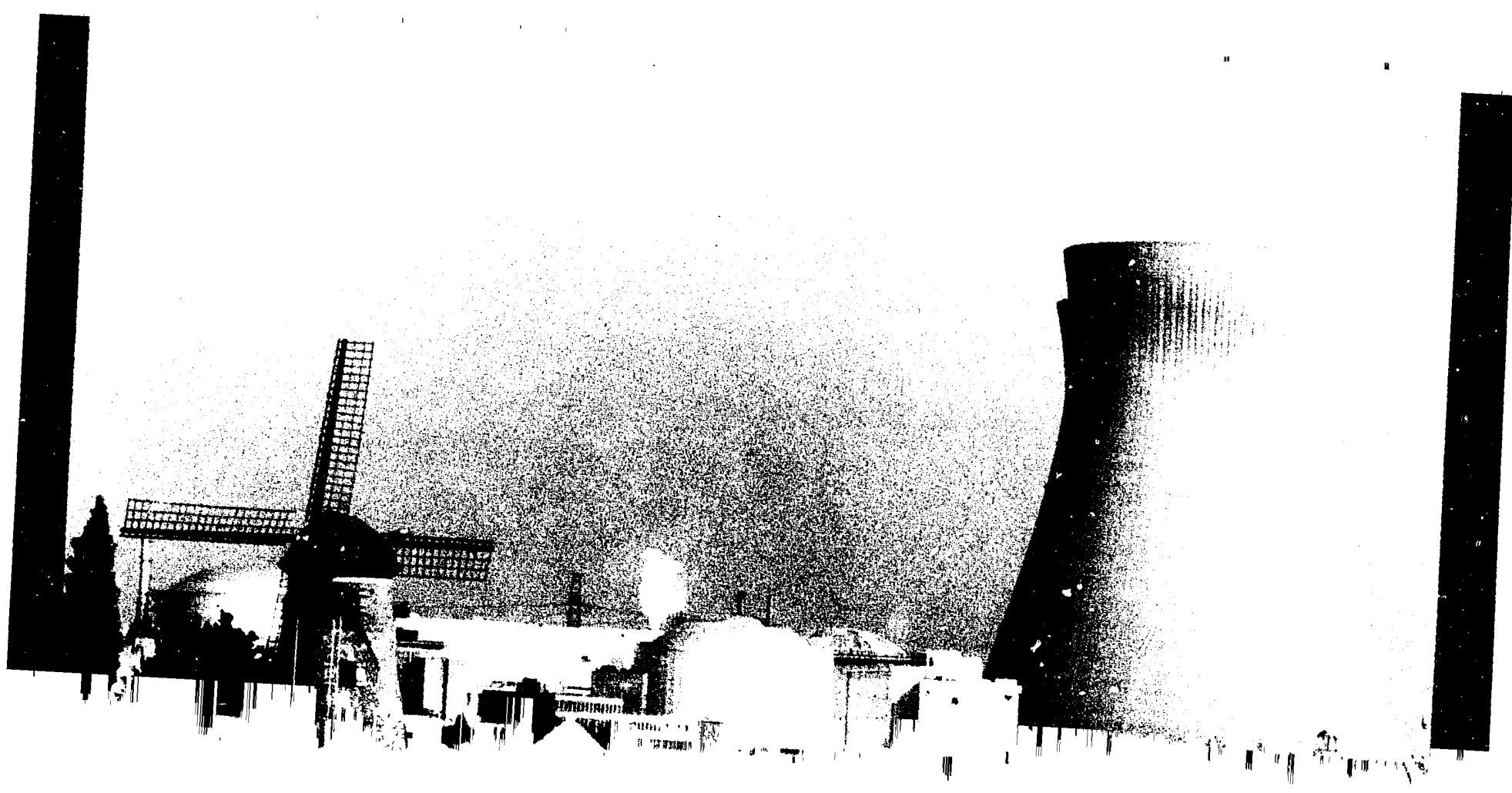


This publication may be purchased from the Superintendent of Documents, U.S. Government Printing Office. Purchasing information for this or other Energy Information Administration (EIA) publications may be obtained from the Government Printing Office or EIA's National Energy Information Center. Questions on energy statistics should be directed to the Center by mail, telephone. or telecommunications device for the hearing impaired. Addresses, telephone numbers, and hours are as follows:

National Energy Information Center. EI-231

Energy Information Administration

Forrestal Building, Room 1F-048

Washington. DC 20585

(202) $586-8800$

Telecommunications Device for the

Hearing Impaired Only: (202) 586-1181

8 a.m. - 5 p.m., eastern time, M-F
Superintendent of Documents U.S. Government Printing Office Washington, DC 20402

(202) 783-3238

FAX 1-202-275-0019

8 a.m. - 5 p.m., eastern time, M-F

\section{Cover Photo:}

The DOEL Nuclear Power Station, located in Antwerp, Belgium, has four pressurized-water reactors with a total capacity of 2,680 net megawatts.

Released for Printing: October 10, 1991 
DOE/EIA- $0436(91)$

\title{
World Nuclear Fuel Cycle Requirements 1991
}

\author{
October 1991
}

Energy Information Administration

Office of Coal, Nuclear, Electric and Alternate Fuels

U.S. Department of Energy

Washington, DC 20585

This report was prepaied by the Energy Information Aúministration, the independent statistical and analytical agency within the Department of Energy. The information contained herein should not be construed as advocating or reflecting any policy position of the Depariment of Energy or of any uther organization.

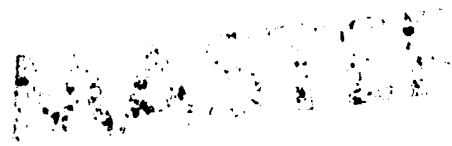




\section{Contacts}

This report was prepared in the Nuclear and Alternate Fuels Division of the Office of Coal, Nuclear, Electric and Alternate Fuels. Questions regarding the contents of the report should be addressed to Howard Walton, Director of the Nuclear and Alternate Fuels Division (202/254-5500), Betsy O'Brien, Chief of the Data Analysis and Forecasting Branch (202/254-5506), William Liggett, the project manager (202/254-5508), or to Diane Jackson, project analyst (202/254-5536). 


\section{Preface}

This analysis report presents the projected requirements for uranium concentrate and uranium enrichment services to fuel the nuclear power plants expected to be operating under three nuclear supply scenarios. Two of these scenarios, the Lower Reference and Upper Reference cases, apply to the United States, Canada, Europe, the Far East, and other countries with free market economies (FME countries). A No New Orders scenario is presented only for the United States. These nuclear supply scenarios are described in Commercial Nuclear Power 1991: Prospects for the United States and the World (DOE/EIA-0438(91)).

This report contains an analysis of the sensitivities of the nuclear fuel cycle projections to different levels and types of projected nuclear capacity, different enrichment tails assays, higher and lower capacity factors, changes in nuclear fuel burnup levels, and other exogenous assumptions. The projections for the United States generally extend through the year 2030, and the FME projections, which include the United States, are provided through 2010.

The report also presents annual projections of spent nuclear fuel discharges and inventories of spent fuel. Appendix D includes annual domestic spent fuel projections through the year 2030 for the Lower and
Upper Reference cases and through 2040 for the No New Orders case. These disaggregated projections are provided at the request of the Department of Energy's Office of Civilian Radioactive Waste Management.

This report is intended for the Congress of the United States, Federal and State agencies, and the nuclear industry. It will be of particular interest to analysts involved in long-term planning for the disposition of radioactive waste generated from the nuclear fuel cycle. The domestic and foreign uranium requirements presented in this report are used as input assumptions in developing the annual report, Domestic Uranium Mining and Milling Industry: Viability Assessment (DOE/EIA-0477).

The International Nuclear Model (INM), used for calculating the projected nuclear fuel cycle requirements in this report, is documented in International Nuclear Model, Volumes I, II, and III, prepared by Systems Sciences, Inc. (Bethesda, Maryland). The documentation and a computer tape containing the programs, data input files, output files for this report, and instructions for use of the model that will allow users to reproduce the results of the study, are available from the National Energy Information Center, Room 1F-048, Forrestal Building, Washington, DC 20585 (202/586-8800). 


\section{Contents}

Executive Summary

ix

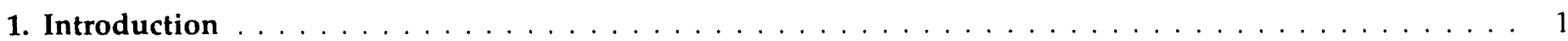

2. Projections of U.S. Nuclear Fuel Cycle Requirements $\ldots \ldots \ldots \ldots \ldots \ldots \ldots \ldots \ldots \ldots \ldots$

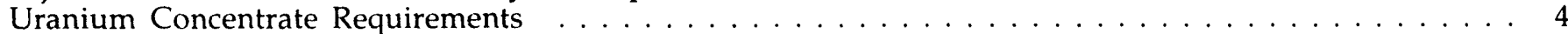

U.S. Uranium Enrichment Service Requirements $\ldots \ldots \ldots \ldots \ldots \ldots \ldots \ldots \ldots \ldots$

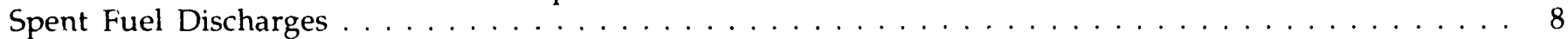

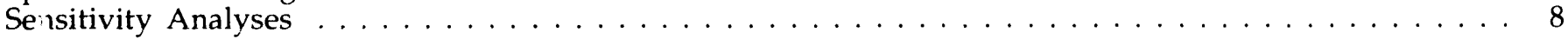

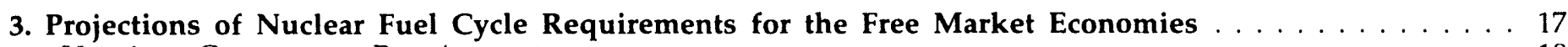

Uranium Concentrate Requirements $\ldots \ldots \ldots \ldots \ldots \ldots \ldots \ldots \ldots \ldots \ldots \ldots$

Uranium Enrichment Service Requirements . . . . . . . . . . . . . . . . . . . . . . . . . . 19

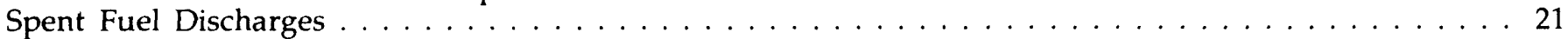

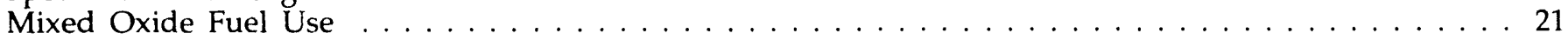

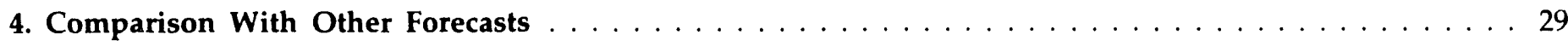

Comparison With Last Year's EIA Report $\ldots \ldots \ldots \ldots \ldots \ldots \ldots \ldots \ldots \ldots \ldots \ldots \ldots$

Comparison With Other Reports . . . . . . . . . . . . . . . . . . . . . . . . . . . . . . . . 29

\section{Appendices}

A. Nuclear Power Technology and the Nuclear Fuel Cycle . . . . . . . . . . . . . . . . . . 39

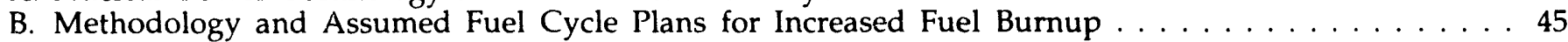

C. Nuclear Fuel Cycle Facilities That Prepare Fuel for Nuclear Power Plants . . . . . . . . . . . . . 53

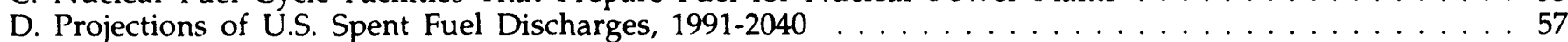

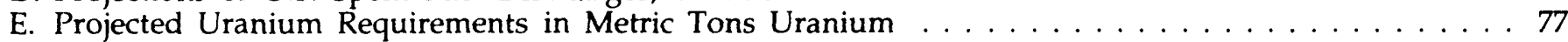

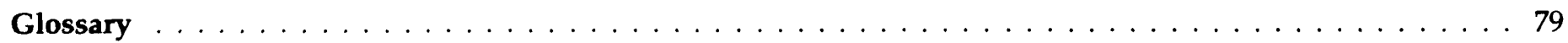


ES1. Projections of U.S. Nuclear Fuel Cycle Requirements, 1991-1995, 2006-2010, 2(126-2030 . . . . . . . . . xi

ES2. Projections of Nuclear Fuel Cycle Requirements for the Free Market Economies,

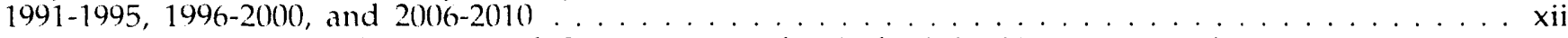

1. U.S. Operable Nuclear Capacity and Generation at the End of the Year, 1990) and Projections for $1995-2030 \ldots \ldots \ldots \ldots \ldots$

2. Projected Average Annual Natural Uranium Requirements for U.S. Nuclear Power Plants,

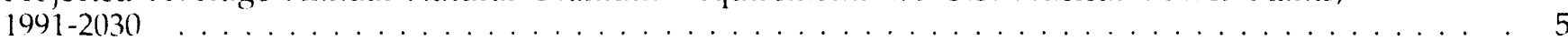

3. Projected Cumulative Natural Uranium Requirements for U.S. Nuclear Power Plants from 1991 . . . 6

4. Projected Average Annual Uranium Enrichment Service Requirements for U.S. Nuclear

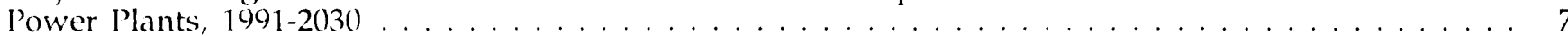

5. Projected Average Annual Spent Fuel Discharges from U.S. Nuclear Power Plants, 1991-2030 . . . . . 9

6. Projected Cumulative Spent Fuel Discharges from U.S. Nuclear Power Plants: Total From 1957 . . . 10

7. Sensitivity of Lower-Reference-Case Projections of U.S. Nuclear Fucl Cycle Requirements

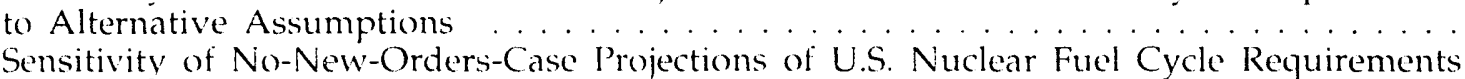

8. Sensitivity of No-New-Orders-Case Projections of U.S. Nuclear Fuel Cycle Requirements

9. Projected Capacity of Foreign Nuclear Power Plants in the Free Market Economies, 1995-2010. . . . 18

10. Projected Average Annual Uranium Requirements for Nuclear Power Plants in the Free Market Economies, 1991-2010

11. Projected Cumulative Uranium Requirements for Nuclear l'ower Plants in the

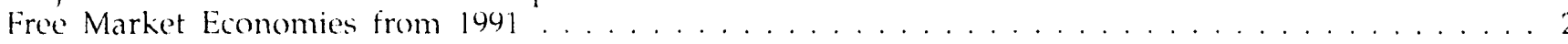

12. Projected Average Annual Uranium Enrichment Service Requirements for Nuclear Power Plants

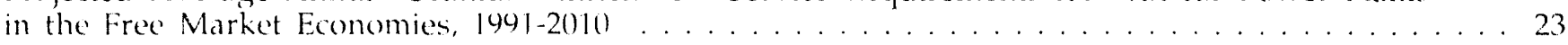

13. Projected Nominal Capacity of World Uranium Enrichment Facilities at the End of the Year, 1990 and 1995

14. Projected Average Annual Discharges of Spent Fuel from Nuclear Power Plants in the

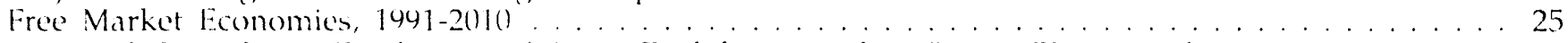

15. Projected Cumulative Discharges of Spent Fuel from Nuclear Power Plants in the

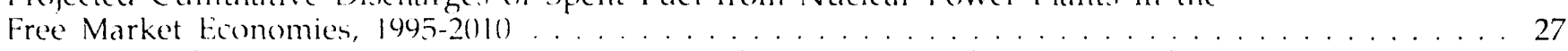

16. Sensitivity of Lower-Reterence-Case l'rojections of European Nuclear Fuel Cycle Requirements

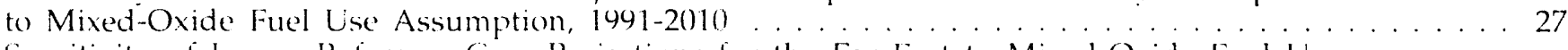

17. Sensitivity of Lower Reference-Case Projections for the Far East to Mixed-Oxide Fuel Use

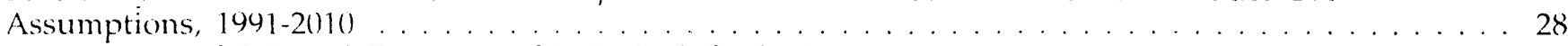

18. Comparison of Selected Forecasts of U.S. Fuel Cycle Requirements . . . . . . . . . . . . . . . . . 30

19 Comparison of Selected Forecasts of Fuel Cycle Requirements for the Free Market Economies,

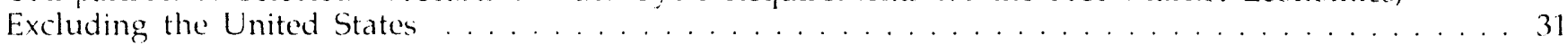

20. Porreitage Error in Predicting Spent Fuel Discharges . . . . . . . . . . . . . . . . . . . . 32

B1. Results of the Regression Analvsis of the Enrichment Assav Equations . . . . . . . . . . . . . . . . 47

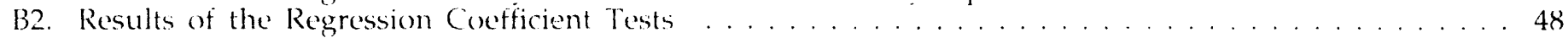

B3. Domestic Fuel Management Plans for Extended Burnup Scenarios . . . . . . . . . . . . . . . . . . 49

B4. Foreign Fuel Management Plans for Extended Burnup Scenarios . . . . . . . . . . . . . . . . . . . 49

C1. Nuclear Fuel Cvele Facilities That Prepare Fuel for Nuclear Power Plants . . . . . . . . . . . . . . . . . 53

D1. P'rojections of Annual L.S. Spent fuel Discharges, 1991-2040 . . . . . . . . . . . . . . . . . . 6 60

D2. Projections of Total U.S. Spent Fuel Discharges, 1991-2040 . . . . . . . . . . . . . . . . . . . 61

D3. Projected Average Annual Burnup of Spent Fuel Discharges by U.S. Nuclear Power Plants

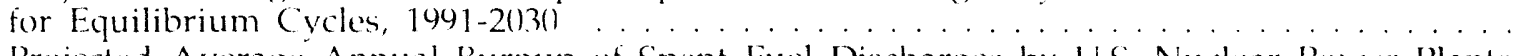

D4. Projected Average Annual Burnup of Spent Fuel Discharges by U.S. Nuclear Power Plants for All Cycles, 1491-2()30

D5. Projected Spent Fuel Discharges by U.S. Reactors in the No New Orders Case, 1941-20)1 . . . . . . 64

D6. Projected Spent Fuel Discharges by U.S. Reactors in the No New Orders Case, 20()2-2011 . . . . . . 66

D7. Projected Spent Fuel Discharges by U.S. Reactors in the N, New Orders Case, 2(1)12-2(121 . . . . . 68

D8. Projected Spent Fuel Discharges by U.S. Reactors in the No New Orders Case, 2(122-2031 . . . . . . 70)

D9. Projected Spent Fuel Discharges by U.S. Reactors in the No New Orders (ase, 2(1).32-2(1)40 . . . . . . 72

E1. Projected Average Annual Uranium Requirements for Nuclear Power Plants in the Free

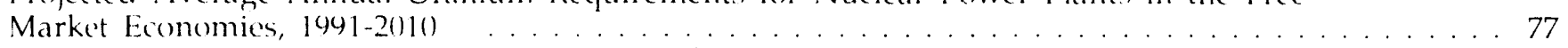

E2. Projected Cumulative Uranium Requirements for Nuclear Power Plants in the Free Market Fonomies, 1991-2010 
1. U.S. Average Annual Uranium Requirements, 1991-2030 . . . . . . . . . . . . . . . . . . . 5

2. U.S. Total Uranium Requirements, $1991-2030 \ldots \ldots \ldots$. . . . . . . . . . . . . . . . . . . . . . . 6

3. U.S. Average Annual Uranium Enrichment Service Requirements, 1991-2030 . . . . . . . . . . . . . . 7

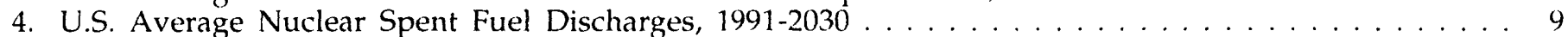

5. U.S. Total Nuclear Spent Fuel Discharges, 1970-2030 . . . . . . . . . . . . . . . . . . . . . . . . 11

6. Average Equilibrium-Cycle Discharge Burnup for U.S. Boiling-Water Reactors, 1972-2010 . . . . . . . 14

7. Average Equilibrium-Cycle Discharge Burnup for U.S. Pressurized-Water Reactors, 1972-2010 . . . . . 15

8. Average Annual Uranium Requirements for the Free Market Economies, 1991-2010 . . . . . . . . . . 20

9. Cumulative Uranium Requirements for the Free Market Economies, 1991-2010 . . . . . . . . . . . 22

10. Average Annual Uranium Enrichment Service Requirements for the Free Market Economies,

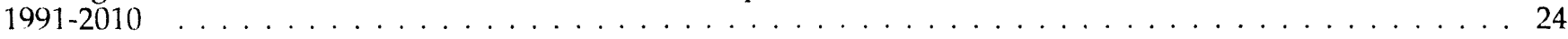

11. Average Annual Nuclear Spent Fuel Discharges for the Free Market Economies, 1991-2010 . . . . . . . 26

12. Comparison of Fuel Cycle Requirements from EIA and Other Reports for the United States,

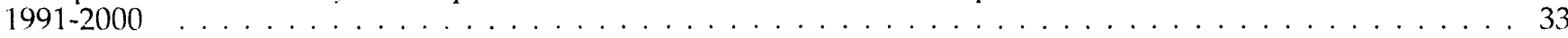

13. Comparison of Fuel Cycle Requirements from ElA and Other Reports for Free Market Economies Excluding the United States, $1991-2000 \ldots \ldots \ldots \ldots$

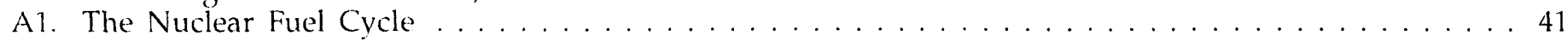




\section{Executive Summary}

The nuclear fuel cycle consists of mining and milling uranium ore, processing the uranium into a form suitable for generating electricity, "burning" the fuel in nuclear reactors, and managing the resulting spent nuclear fuel. This report presents projections of domestic and foreign requirements for natural uranium and enrichment services as well as projections of discharges of spent nuclear fuel. These fuel cycle requirements are based on the forecasts of future commercial nuclear power capacity and generation published in a recent Energy Information Administration (EIA) report.' Also included in this report are projections of the amount of spent fuel discharged at the end of each fuel cycle for each nuclear generating unit in the United States.

\section{Assumptions}

\section{Domestic}

Three nuclear supply reference scenarios for the United States (No New Orders, Lower Reference, and Upper Reference) are included in this report. These scenarios reflect different assumptions about schedules for construction of nuclear power plants, cancellations, operating license renewal, and new orders for reactors. In the Lower Reference and Upper Reference cases, the United States is projected to have 123 and 152 net gigawatts-electric (GWe) of operable nuclear power capacity, respectively, in the year 2020. In the No New Orders case, it is projected that there will be only 57 net GWe of capacity that year because reactors are assumed to be retired 40 years after the issuance of their operating license, and no nuclear capacity replacement is assumed. By the year 2030, the Lower and Upper Reference cases show operable nuclear capacity of 137 and 190 (GWe), respectively. The No New Orders case declines to 7 GWe by 2030.

In addition to studying the effects of three scenarios of projected nuclear power capacity, seven sensitivity cases based on the nuclear capacities of the No New Orders and Lower Reference cases, are examined to determine the potential effects of varied assumptions on projected fuel cycle requirements. The basic assumptions used for the domestic projections are as follows:
- Capacity factors in the equilibrium cycle range from 64 percent in 1991 to a high of 73 percent in 2030.

- The enrichment tails assay (the concentration of the uranium isotope U-235 in the waste stream from the enrichment process) is at 0.30 percent in 1991 through 2000, then drops to 0.25 percent by 2005 and remains constant through 2030 . Year-by-year tails assay assumptions are displayed in the main body of the report.

- Design burnup, a measure of the amount of energy obtained from the fuel in a reactor, increases from about 33,000 megawattdays thermal per metric ton of initial heavy metal (MWDT/MTIHM) in 1991 to 43,000 MWDT/ MTIHM in 2007 and beyond for boiling-water reactors, and from about 40,000 MWDT/ MTIHM in 1991 to 55,000 MWDT/MTIHM in 2005 and beyond for pressurized-water reactors. Appendix B shows specific design burnup assumptions by year and other important factors about the fuel plans.

- Plants are retired after 40 years of operation in the No New orders case. Plant operating licenses are renewed to 60 years for 70 percent of existing installed capacity for the Lower and Upper Reference cases.

The seven domestic sensitivity cases are as follows:

1. Capacity factors in the equilibrium cycle remain constant at about 64 percent from 1991 through 2030.

2. Capacity factors in the equilibrium cycle increase to 69 percent by 1998 and 75 percent by 2030 .

3. The enrichment tails assay is 0.2 percent in each year of the projection.

4. The enrichment tails assay is 0.3 percent in each year of the projection.

'Energy Information Administration, Commercial Nuclear Power 1991: Prospects for the United States and the World, DOE/EIA-0438(91) (Washington, DC, August 1991). 
5. No increase in design burnup occurs beyond 1991 levels.

6. The design burnup : :creases at an accelerated pace and increases to 46,000 MWDT/MTIHM for boiling-water reactors in 2015 and 60,000 MWDT/MTIHM for pressurized-water reactors in 2013.

7. Plant operating licenses are renewed to 60 years for 70 percent of installed capacity for the No New Orders case and no license renewal is assumed in the Lower Reference case (i.e., a 40year life for reactors in the Lower Reference case).

\section{Free Market Economies}

Two nuclear supply scenarios (Lower Reference and Upper Reference) are used for countries with free market economies (FME countries). ${ }^{2}$ For the FME countries, excluding the United States, nuclear power capacity is projected to range from 224 to 284 GWe in the year 2010 for the Lower and Upper Reference cases, respectively. By the end of 1990, 243 nuclear reactors were operable in the FME countries (excluding the United States), representing 180 net GWe of nuclear capacity, and 59 units were in the construction pipeline totaling about 54 net GWe. The basic assumptions used for the projections are as follows:

- Capacity factors range from 67 percent to 71 percent during the projection period. This is an average for all FME countries (including the United States).

- Enrichment tails assay for light-water reactors is kept constant at 0.25 percent during the projection period (excluding the United States, which was noted above).

- Design burnup for nuclear units in Europe and the Far East goes from about 33,000 MWDT/ MTIHM in 1991 to $43,000 \mathrm{MWDT} / \mathrm{MTIHM}$ in 2004 and beyond for boiling-water reactors, and from about 35,000 MWDT/MTIHM in 1991 to $50,000 \mathrm{MWDT} / \mathrm{MTIHM}$ in 2004 and beyond for pressurized-water reactors. Appendix B shows specific design burnup assumptions by year and other important factors about the fuel plans.

- Plants are retired after 30 years of operation.

\section{Projections}

\section{Domestic}

In the Lower Reference case for the United States, the average annual domestic requirements for uranium concentrate are projected to increase from an average of 41.8 million pounds $\mathrm{U}_{3} \mathrm{O}_{8}$ in 1991 through 1995 to 52.1 million pounds by the years 2026 through 2030 (Table ES1). The required enrichment services are projected to increase from an annual average of 8.6 million separative work units in 1991 through 1995 to 15.0 million separative work units for the years 2026 through 2030. The total amount of spent fuel projected to be in inventory at the end of 1995 is 31.6 thousand metric tons of initial heavy metal and is expected to grow to 101.7 thousand metric tons by 2030. At the end of 1990, there were 21.9 thousand metric tons in inventory which utilities do not currently plan to irradiate further.

Uncertainty about future nuclear capacity produces the largest variation in projected fuel cycle requirements and spent fuel discharges. For example, in the No New Orders case the total spent fuel discharged through 2030 is 16.4 percent less than in the Lower Reference case, and average annual uranium concentrate, and enrichment service requirements in the years 2026 through 2030 are 93.1 percent and 90.7 percent less, respectively.

Changes in capacity factors affect both the amount of electricity generated by nuclear units and the amount of fuel consumed. In general, lower capacity factors result in lower aggregate requirements for uranium concentrate and enrichment services and lower spent fuel discharges, while higher capacity factors have the opposite effect. However, changes in capacity factor can also change the date that a nuclear unit refuels if it operates until the planned burnup of the fuel is achieved.

The choice of a tails assay affects natural uranium and enrichment requirements. For a given enriched uranium product, the natural uranium required as feed for the enrichment process decreases and the enrichment services increase when a lower tails assay is selected. The opposite occurs for higher tails assays. The U.S. Department of Energy's Utility Services Enrichment Contract allows customers to select a tails assay between 0.2 and 0.3 percent U-235. Because minimum reactor fuel cost is a criterion for selecting

${ }^{2}$ FME countries include the United States, Canada, Belgium, Finland, France, Western Germany, Italy, Netherlands, Spain, Sweden, Switzerland, United Kingdom, Yugoslavia, Japan, South Korea, Taiwan, Argentina, Brazil, India, Mexico, Pakistan, and South Africa. 
Table ES1. Projections of U.S. Nuclear Fuel Cycle Requirements, 1991-1995, 2006-2010, and 2026-2030

\begin{tabular}{|c|c|c|c|c|c|c|c|c|c|}
\hline \multirow[b]{2}{*}{ Assumptions } & \multicolumn{3}{|c|}{$\begin{array}{c}\text { Average Annual } \\
\text { Natural Uranium } \\
\text { Requirements } \\
\text { (million pounds } \mathrm{U}_{3} \mathrm{O}_{8} \text { equivalent) }\end{array}$} & \multicolumn{3}{|c|}{$\begin{array}{c}\text { Average Annual } \\
\text { Uranium Enrichment Service } \\
\text { Requirements } \\
\text { (million separative work units) }\end{array}$} & \multicolumn{3}{|c|}{$\begin{array}{l}\text { Total Spent Fuel } \\
\text { Discharges } \\
\text { (thousand metric tons } \\
\text { of initial heavy metal) }\end{array}$} \\
\hline & $\begin{array}{l}1991- \\
1995\end{array}$ & $\begin{array}{l}2006- \\
2010\end{array}$ & $\begin{array}{l}2026- \\
2030\end{array}$ & $\begin{array}{l}1991- \\
1995\end{array}$ & $\begin{array}{l}2006- \\
2010\end{array}$ & $\begin{array}{l}2026- \\
2030\end{array}$ & 1995 & 2010 & 2030 \\
\hline $\begin{array}{l}\text { Lower-Reference-Case } \\
\text { Value } \ldots \ldots \ldots \ldots\end{array}$ & $\begin{array}{c}41.8 \\
a(16.1)\end{array}$ & $\begin{array}{c}42.6 \\
\mathrm{a}(16.4)\end{array}$ & $\begin{array}{c}52.1 \\
\mathrm{a}(20.0)\end{array}$ & 8.6 & 11.6 & 15.0 & 31.6 & 60.1 & 101.7 \\
\hline \multicolumn{10}{|c|}{ Percent Differences from Lower Reference Case Due to Variations in Assumptions } \\
\hline $\begin{array}{l}\text { Nuclear Growth } \\
\text { No New Orders . . . . . } \\
\text { Upper Reference Case . }\end{array}$ & $\begin{array}{l}0.0 \\
0.0\end{array}$ & $\begin{array}{r}-10.0 \\
6.6\end{array}$ & $\begin{array}{r}-93.1 \\
38.0\end{array}$ & $\begin{array}{l}0.0 \\
0.0\end{array}$ & $\begin{array}{r}-10.0 \\
5.0\end{array}$ & $\begin{array}{r}-90.7 \\
36.8\end{array}$ & $\begin{array}{l}0.0 \\
0.0\end{array}$ & $\begin{array}{l}0.3 \\
0.0\end{array}$ & $\begin{array}{r}-16.4 \\
9.2\end{array}$ \\
\hline $\begin{array}{l}\text { With Lower } \\
\text { Capacity Factors . . . . . }\end{array}$ & . . $\quad-1.2$ & -7.7 & -7.5 & 0.0 & -3.4 & -9.8 & 0.0 & -1.5 & -5.0 \\
\hline $\begin{array}{l}\text { With Higher } \\
\text { Capacity Factors }\end{array}$ & 2.3 & 0.0 & 7.3 & 3.7 & 0.4 & 11.5 & 0.6 & 1.5 & 2.0 \\
\hline With Lower Tails Assay & $\ldots-17.2$ & -8.6 & -8.7 & 24.7 & 12.1 & 12.0 & 0.0 & 0.0 & 0.0 \\
\hline With Higher Tails Assay & 0.0 & 10.8 & 10.8 & 0.0 & -9.4 & -9.3 & 0.0 & 0.0 & 0.0 \\
\hline $\begin{array}{l}\text { With Less Increase } \\
\text { in Fuel Burnup } \ldots . . .\end{array}$ & . -1.1 & 2.8 & 6.3 & -0.7 & -2.0 & -1.7 & 0.0 & 3.8 & 13.1 \\
\hline With Higher Fuel Burnup & 0.5 & -1.4 & -2.3 & 0.0 & -1.7 & 0.6 & 0.0 & -2.0 & -2.9 \\
\hline With No License Renewal & 0.0 & -1.7 & -47.5 & 0.0 & -1.7 & -47.2 & 0.0 & 0.5 & -5.2 \\
\hline
\end{tabular}

${ }^{a}$ Numbers shown in parentheses under uranium requirements are thousand metric tons of uranium.

Source: Projected fuel cycle requirements calculated using the International Nuclear Model, based on capacity projections from Energy Information Administration, Commercial Nuclear Power 1991: Prospects for the United States and the World, DOE/EIA-0438(91) (Washington, DC, August 1991).

a tails assay, the choice depends on the prices of natural uranium and enrichment, as well as on the quantities of each that would be required. In the years 2026 through 2030, a tails assay of 0.3 percent rather than the base case assumption of 0.25 percent increases the average annual requi ements for natural uranium by 10.8 percent and decreases the average annual enrichment service requirements by approximately 9.3 percent.

Recently, electric utilities have been able to increase the burnup for their reactors by increasing the concentration of U-235 in the enriched uranium fuel and changing the design specifications of the fuel rods. At higher fuel burnups, the length of the operating cycle is increased and/or a smaller fraction of the core is replaced at each fuel loading. For this report, it is assumed that a nuclear unit will operate until the planned burnup of the fuel is achieved. As shown in Table ES1, without this continued increase in future burnup levels, the total spent fuel discharged will be 13.1 percent higher than the Lower Reference case in 2030 and the average annual natural uranium and enrichment requirements in 2026 through 2030 will be 6.3 percent higher and 1.7 purcent lower, respectively, than the Lower Reference case. If burnup levels rise above the level achieved in the Lower Reference case, total spent fuel discharges will be 2.9 percent lower in 2030 .

\section{Free Market Economies}

Average annual uranium requirements for the FME nations are projected to be 13 percent higher in the years 2006 through 2010 than for the years 1991 through 1995 in the Lower Reference case (Table ES2). 
Table ES2. Projections of Nuclear Fuel Cycle Requiremenis for the Free Market Economies, 1991-1995, 1996-2000, and 2006-2010

Lower-Reference Case Values

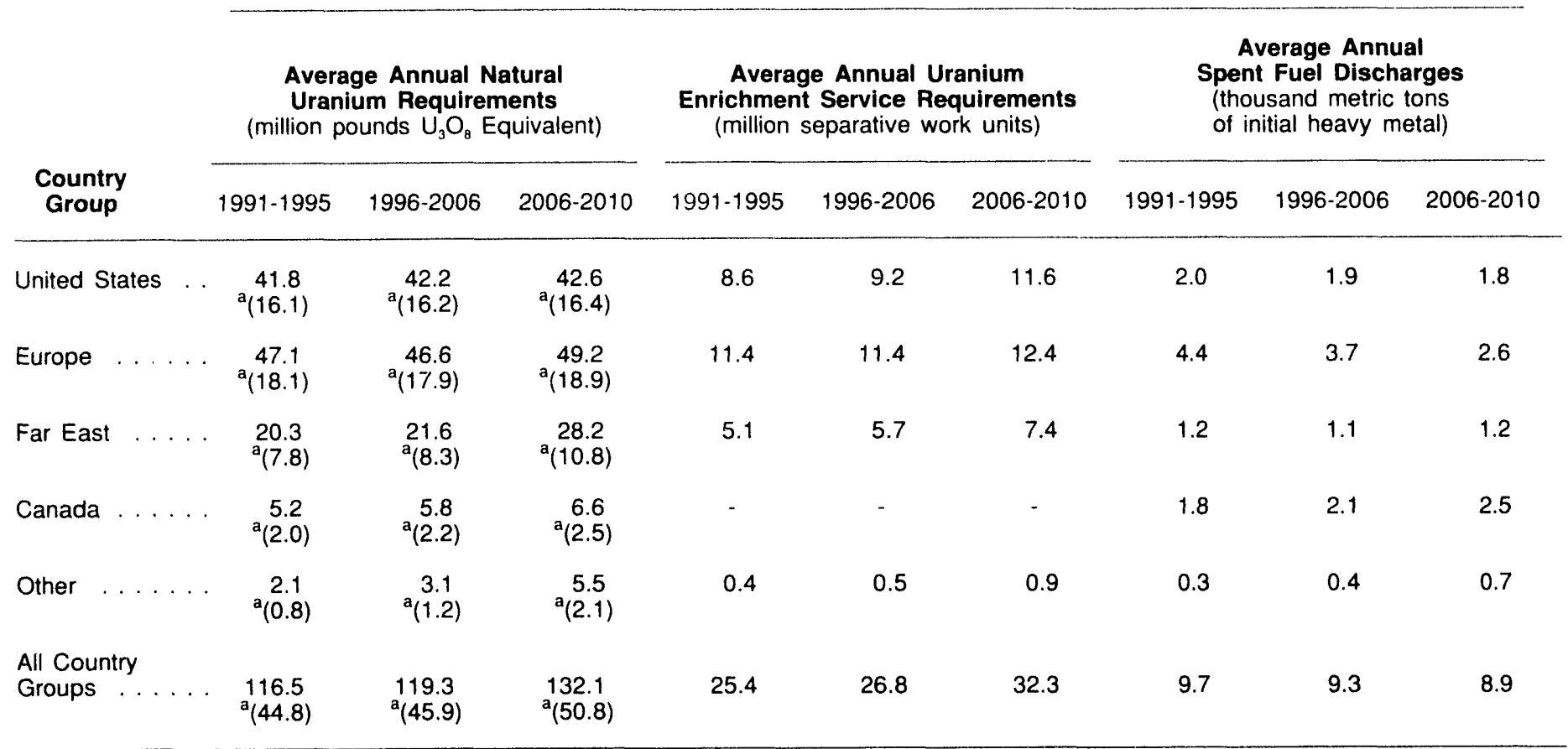

a Numbers shown in parentheses under uranium requirements are thousand metric tons of uranium.

Source: Projected fuel cycle requirements using the International Nuclear Model, based on capacity projections from Energy Information Administration, Commercial Nuclear Power 1991: Prospects for the United States and the World, DOE/EIA-0438(91) (Washington, DC, August 1991).

The United States accounts for about 36 percent of the annual uranium requirements in the years 1991 through 1995. Average annual uranium enrichment service requirements are projected to be 27 percent higher in the years 2006 through 2010 than for the years 1991 through 1995. The United States accounts for about 34 percent of the annual enrichment services in the years 1991 through 1995. Average annual spent fuel discharges are projected to range from 9.7 thousand metric tons per year in 1991 through 1995, declining to an average of 8.9 thousand metric tons per year for the years 2006 through 2010 . This decline in spent fuel is a result of achieving higher fuel burnup for these years. 


\section{Introduction}

This report presents historical data and projections of the nuclear fuel cycle requirements for reactors in the Uniked States and other countries with free market economies (FME countries). The projections in the body of the report are provided for the United States through 2030 and for the other FME countries through 2010. Appendix D contains annual projections of spent fuel discharges for the United States through 2040 in the No New Orders case anc through 2030 in the other cases. A recent EIA report provides the basis for the underlying nuclear power capacity projections.'

This repcrt contains projections for three elements of the nuclear fuel cycle: (1) requirements for $\mathrm{U}_{3} \mathrm{O}_{8}$, (2) requirements for enrichment services, and (3) discharges of spent fuel. "Requirenients" refer to the quantities needed for initial fueling or refueling of reactors and not to demand in the marketplace or to actual production. For example, the requirements for $\mathrm{U}_{3} \mathrm{O}_{8}$ may be met by scheduled contract deliveries from domestic or foreign producers, purchases on the spot market, or use of inventories held by utilities. Likewise, the requirements for enrichment services may be satisfied by contracts with DOE or with foreign enrichers, and also from inventories of enriched uranium, or secondary market transactions. Information on uranium reserves, production, and market transactions can be found in the Energy Information Administration report, Uranium Industry Annual 1991 (DOE/EIA-0478(91)).

The projections in this report serve various purposes. Projections of discharges of spent fuel in the United States for the No New Orders case through the year 2040, the last year in which fuel is discharged, and through 2030 for the other cases (Appendix D), are provided at the request of U.S. Department of Energy's (DOE) Office of Civilian Radioactive Waste Management, to estimate the long-term need for waste repositories. Projections of domestic and foreign requirements for uranium and enrichment services are used for the viability assessment of the domestic uranium mining and milling industry and to evaluate potential markets for enrichment services.

This report consists of four chapters. Chapter 2, "Projections of Domestic Nuclear Fuel Cycle Requirements," discusses the assumptions and results for the United States; Chapter 3, "Projections of FME Nuclear Fuel Cycle Requirements," does the same for the foreign sector. Chapter 4 contains a comparison of the projections in this report with projections by private companies. Throughout the report, comparisons are made between projections for different years for each nuclear supply scenario. Usually, comparisons are selected to show the largest differences, in order to emphasize the impacts of the different scenarios on fuel requirements.

The appendices contain a brief discussion of the nuclear fuel cycle and the major components of the cycle (Appendix A); the methodology used in developing the projection.s contained in this report and the fuel management plans that were used (Appendix B); a list of conversion, enrichment, and fabrication facilities in the wrorld (Appendix C); tables of the aggregated annv-l and cumulative domestic spent fuel projection: and projections of spent fuel discharges at the end of each fuel cycle for each nuclear generating unit (Appendix D); and uranium requirements for Free Market Economies in metric tons of uranium (Appendix E). 


\section{Projections of U.S. Nuclear Fuel Cycle Requirements}

This chapter presents projections of uranium concentrate $\left(\mathrm{U}_{3} \mathrm{O}_{8}\right)$ requirements, enrichment service requirements, and spent fuel discharges based on the three domestic nuclear supply scenarios-No New Orders, Lower Reference, and Upper Reference. The three nuclear supply scenarios differ primarily in the dates in which reactors currently in the construction pipeline come online, the number of assumed newly ordered units, and the timing of their initial operation. Sensitivity cases to the basic assumptions underlying the proji t $^{\prime}$, ns using the No New Orders and Lower Reference are also examined. The basic assumptions used for the projections are as follows:

- Capacity factors in the equilibrium cycle range from 64 percent in 1991 to 73 percent in 2030.

- The enrichment tails assay is at 0.30 percent in 1991 through 2000, and then drops to 0.25 percent by 2005 and is expected to remain constant through 2030. Year-by-year tails assay assumptions are displayed later in the chapter.

- Design burnup goes from about 33,000 megawattdays thermal per metric ton of initial heavy metal (MWDT/MTIHM) in 1991 to 43,000 MWDT/MTIHM in 2007 and beyond for boiling water reactors and from about 40,000 MWDT/ MTIHM in 1991 to 55,000 MWDT/MTIHM in 2005 and beyond for pressurized-water reactors. Appendix $B$ shows specific design burnup assumptions by year and other important factors about the fuel plans.

- Plants are retired after 40 years of operation in the No New Orders case. Plant operating licenses are renewed to 60 years for 70 percent of existing installed capacity for the Lower and Upper Reference cases.

Fuel requirements and spent fuel discharges are presented as 5-year averages to indicate general trends for comparison across cases. This helps to smooth out the variation in annual projections. Variation occurs because, as new plants come on line, the first fuel loading uses three to four times the quantity of fuel used for subsequent reloads. Also contributing is the fact that most reactors are not refueled annually, so that large variations in requirements occur when a significant number of reactors do not refuel in a year.

Installed nuclear capacity at year end 1990 was 99.6 GWe with 111 operable nuclear reactors, and the overall capacity factor during the year was 66.1 percent. As of December 31, 1990, there were eight nuclear units with a total capacity of $9.6 \mathrm{GWe}$ in the "construction pipeline." Of these, construction of five units has been indefinitely deferred. There were 119 nuclear units in operation and in the pipeline at yearend with a combined net summer capability of 109.2 GWe. ${ }^{2}$ The amount of spent fuel that was discharged from domestic nuclear reactors in 1990 was 2.2 thousand metric tons, bringing the total spent fuel inventory, as of the end of 1990, to 21.9 thousand metric tons of initial heavy metal.

Table 1 summarizes the projections of domestic nuclear capacity and electricity generation for three nuclear supply scenarios-No New Orders, Lower Reference, and Upper Reference-from 1995 through 2030.

Projected capacity through the year 2005 reaches 107 net GWe for all three scenarios. Under the Lower and Upper Reference cases, capacity increases to 123 and 152 net GWe, respectively by the year 2020. By the year 2030, nuclear capacity of the United States is projected to reach 137 net GWe in the Lower Reference case and 190 GWe in the Upper Reference Case. In the No New Orders case, there is projected to be only 57 net GWe of operating nuclear capacity in the year 2020 due to retirement of existing units with no replacement. Capacity under this scenario drops to 7 net GWe by the year 2030 .

It is important to note that uranium concentrate requirements and enrichment service requirements follow the trends in projected operable capacity. That

${ }^{2}$ Source: Energy Information Administration, Commercial Nuclear Power 1991: Prospects for the United States and the World, DOE/EIA0438(91) (Washington, DC, August 1991). 
Table 1. U.S. Operable Nuclear Capacity and Generation at the End of the Year, 1990 and Projections for 1995-2030

\begin{tabular}{|c|c|c|c|c|c|c|}
\hline \multirow[b]{2}{*}{ Year } & \multicolumn{3}{|c|}{ Capacity (Net GWe) } & \multicolumn{3}{|c|}{ Generation (Net TWh) } \\
\hline & $\begin{array}{c}\text { No New } \\
\text { Orders } \\
\text { Case }\end{array}$ & $\begin{array}{c}\text { Lower } \\
\text { Reference } \\
\text { Case }\end{array}$ & $\begin{array}{c}\text { Upper } \\
\text { Reference } \\
\text { Case }\end{array}$ & $\begin{array}{c}\text { No New } \\
\text { Orders } \\
\text { Case }\end{array}$ & $\begin{array}{c}\text { Lower } \\
\text { Reference } \\
\text { Case }\end{array}$ & $\begin{array}{c}\text { Upper } \\
\text { Reference } \\
\text { Case }\end{array}$ \\
\hline 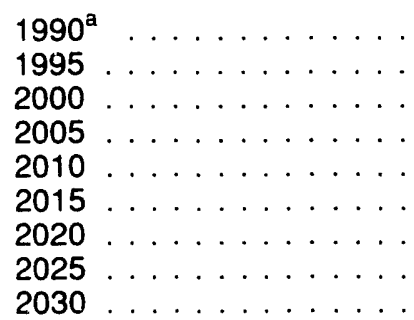 & $\begin{array}{r}100 \\
103 \\
105 \\
107 \\
101 \\
70 \\
57 \\
29 \\
7\end{array}$ & $\begin{array}{l}100 \\
103 \\
105 \\
107 \\
104 \\
114 \\
123 \\
130 \\
137\end{array}$ & $\begin{array}{l}100 \\
103 \\
105 \\
107 \\
110 \\
132 \\
152 \\
171 \\
190\end{array}$ & $\begin{array}{r}577 \\
570 \\
594 \\
614 \\
611 \\
434 \\
349 \\
207 \\
49\end{array}$ & $\begin{array}{l}577 \\
570 \\
592 \\
612 \\
623 \\
698 \\
753 \\
808 \\
877\end{array}$ & $\begin{array}{r}577 \\
570 \\
594 \\
614 \\
654 \\
788 \\
935 \\
1,064 \\
1,213\end{array}$ \\
\hline
\end{tabular}

${ }^{\text {a Actual data. }}$

Note: Capacity values are based on net summer capability.

Source: Eriergy Information Administration, Commercial Nuclear Power 1991: Prospects for the United States and the World, DOE/EIA-0438(91) (Washington, DC, August 1991).

is, for example, an increase in operable capacity will generally imply a corresponding increase in uranium concentrate and enrichment services. As the reader can observe in the sections that follow, the trends in uranium and enrichment services requirements are similar to the trends in operable capacity for each scenario shown in Table 1 . There are other key factors, however, that affect these requirements. For example, the assay levels used for the enriched uranium to achieve higher fuel burnups and the tails assay used when enriching the uranium affect both the requirements for uranium concentrate and enrichment services. The relationship of the enrichment and tails assays to uranium and enrichment services is discussed in more detail in the section on sensitivity analysis.

\section{Uranium Concentrate Requirements}

In the years 1991 through 1995, the average annual $\mathrm{U}_{3} \mathrm{O}_{8}$ requirements are projected to be 41.8 million pounds in all three cases (Table 2 and Figure 1). The requirements are projected for the year the $\mathrm{U}_{3} \mathrm{O}_{8}$ is delivered to a conversion plant ( 15 months prior to startup of a reactor) and, therefore, depend on reactors projected to begin operating in 1992 through early 1997. Reactors projected to enter commercial operation in 1991 are assumed to have their first core requirements already scheduled. The broad range in uranium requirements for 2016 through 2020 and the following years is due to the large difference in projections of domestic nuclear power plant capacity. Average annual requirements for $\mathrm{U}_{3} \mathrm{O}_{8}$ are projected to decline 48 percent from their 1991 through 1995 level by the years 2016 through 2020 in the No New Orders case (where no orders for new nuclear reactors are assumed to be placed through 2020). By the years 2026 through 2030 annual requirements will be 3.6 million pounds. In the Upper Reference case, average annual $\mathrm{U}_{3} \mathrm{O}_{8}$ requirements are projected to grow from 41.8 million pounds in the years 1991 through 1995 to 71.9 million pounds in the years 2026 through 2030 .

The cumulative uranium concentrate requirements in the three cases total slightly more than 420 million pounds through the year 2000 (Table 3 and Figure 2). By the year 2010, the No New Orders Case projects cumulative uranium requirements to be about 809 million pounds compared to 848 million pounds in the Upper Reference Case. This represents about a 5 percent difference between the two. In 2020, the difference between the two cases is about 34 percent increasing to about 86 percent in 2030. The wide ranges for the year 2015 and beyond are due to the wide divergence in the projected new orders for nuclear power plants and the resulting requirements for uranium concentrate for initial fuel loading and refueling. 
Table 2. Projected Average Annual Natural Uranium Requirements for U.S. Nuclear Power Plants, 1991-2030

(Million Pounds $\mathrm{U}_{3} \mathrm{O}_{8}$ Equivalent)

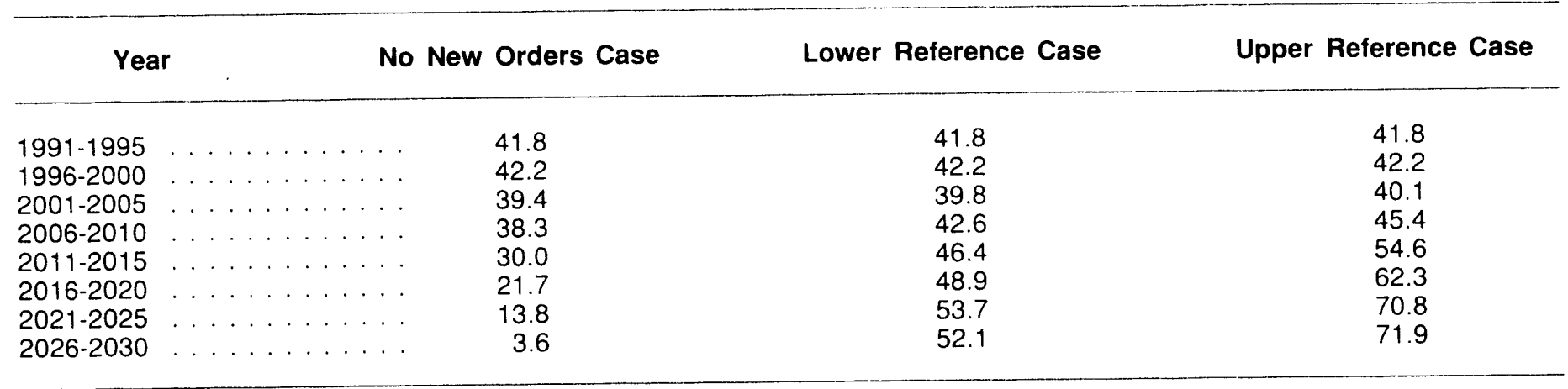

Source: Projected uranium requirements calculated using the International Nuclear Model, based on capacity projections from Energy Information Administration, Commercial Nuclear Power 1991: Prospects for the United States and the World, DOE/EIA-0438(91) (Washington, DC, August 1991).

Figure 1. U.S. Average Annual Uranium Requirements, 1991-2030

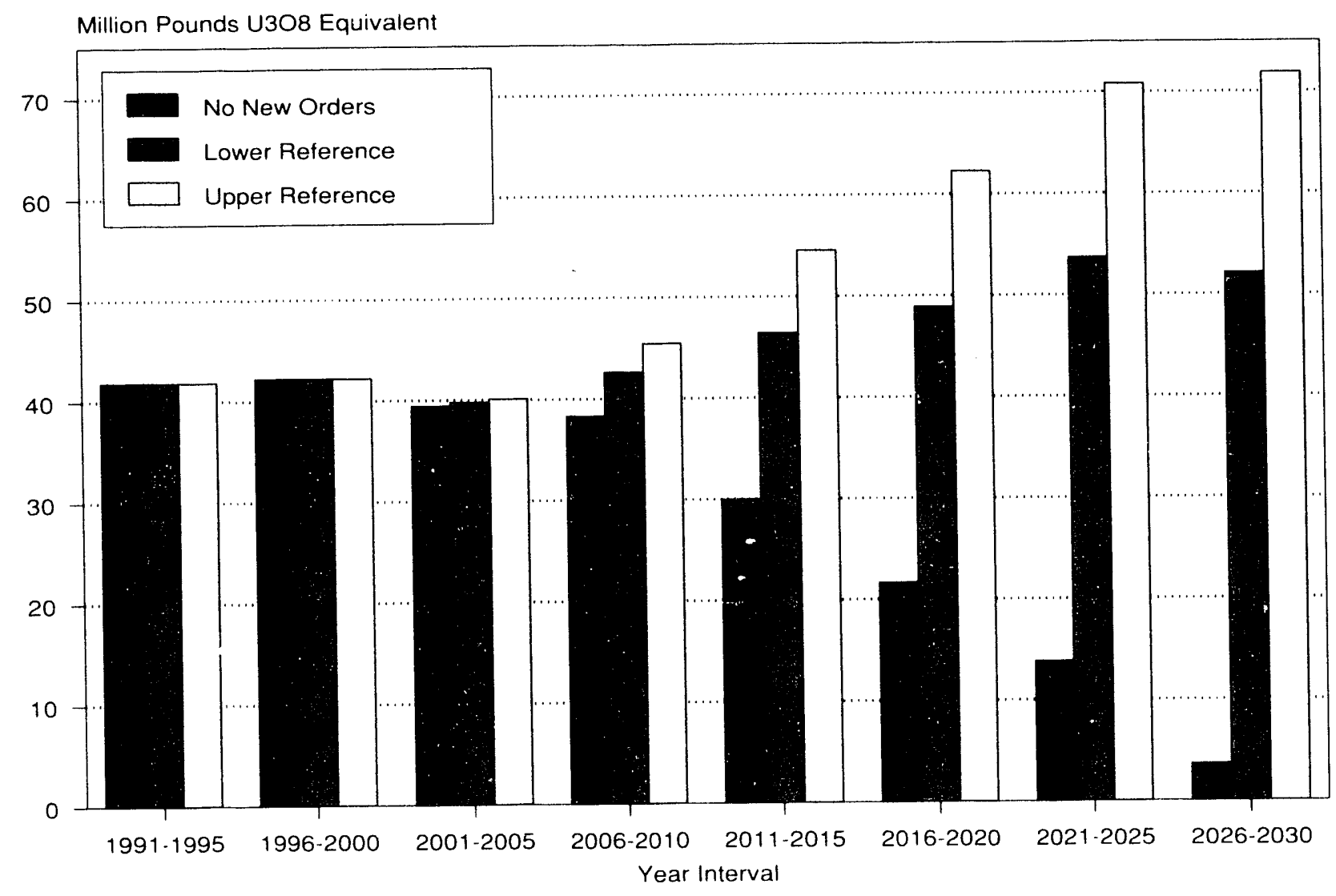

Source: Projected uranium requirements calculated using the International Nuclear Model, based on capacity projections from Energy Information Administration, Commercial Nuclear Power 1991: Prospects for the United States and the World, DOE/EIA-0438(91) (Washington, DC, August 1991). 
Table 3. Projected Cumulative Natural Uranium Requirements for U.S. Nuclear Power Plants from 1991 (Million Pounds $\mathrm{U}_{3} \mathrm{O}_{8}$ Equivalent)

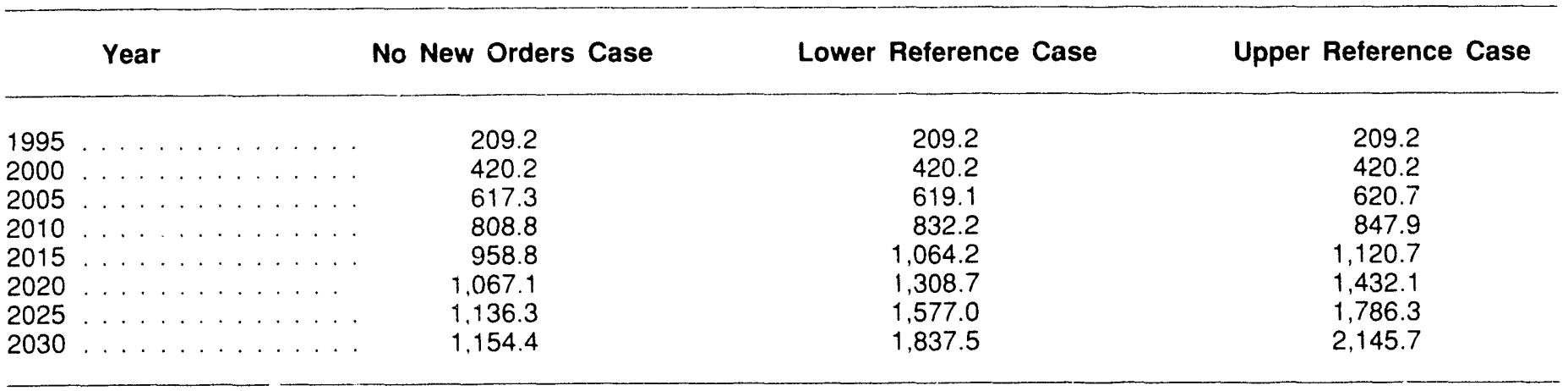

Source: Projected uranium requirements calculated using the International Nuclear Model, based on capacity projections from Energy Information Administration. Commercial Nuclear Power 1991: Prospects for the United States and the World, DOE/EIA-0438(91) (Washington, DC, Âugust 1991).

Figure 2. U.S. Total Uranium Requirements, 1991-2030

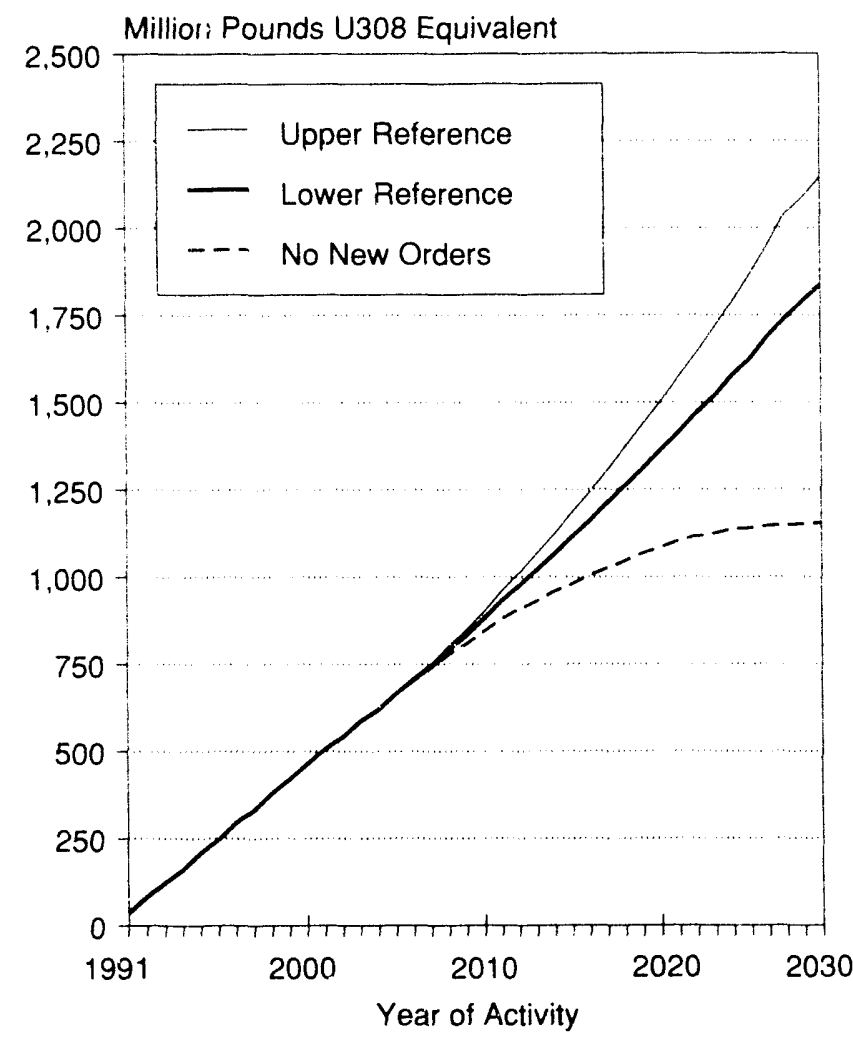

Source: Projected uranium requirements calculated using the International Nuclear Model, based on capacity projections from Energy Information Administration, Commercial Nuclear Power 1991: Prospects for the United States and the World, DOE/EIA-0438(91) (Washington, DC, August 1991).

\section{U.S. Uranium Enrichment Service Requirements}

Average annual enrichment service requirements for the three basic scenarios are shown in Table 4 and Figure 3. Under typical uranium enrichment transaction terms, natural $U_{\mathrm{b}}$ enrichment feed is required 12 months before the start of a reactor's cycle, and enriched $\mathrm{UF}_{6}$ is required 9 months before the start of the cycle. This allows sufficient time for fabricating the fuel into rods and then into assemblies for loading into the core. Similar to the requirements for natural uranium, the projected requirements for enrichment services are not particularly sensitive to different case assumptions through 2005. After 2005, however, the projected average annual enrichment service requirements in the three Reference cases begin to diverge, and by the years 2016 through 2020 there are marked differences in the projecticns. As mentioned previously, the reason for this difference is because the projected installed capacity is substantially different between these scenarios starting after 2005 . Enrichment service requirements in the No New Orders case differ significantly from those in the other cases after 2005, when the retirement of existing reactors and the introduction of new reactors become the controlling factors. In the years 2016 through 2020, the projected average annual enrichment service requirements in the No New Orders case are about 36 percent of those in the Upper Reference case decreasing to only 7 percent in the years 2026-2030. 
Table 4. Projected Average Annual Uranium Enrichment Service Requirements for U.S. Nuclear Power Plants, 1991-2030

(Million Separative Work Units)

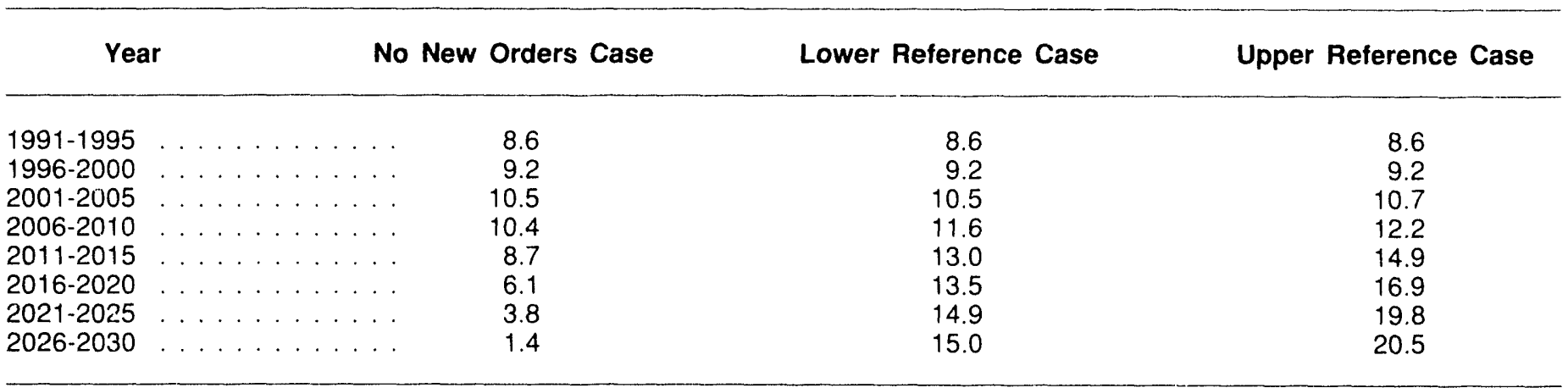

Source: Projected uranium requirements calculated using the International Nuclear Model, based on capacity projections from Energy Information Administration, Commercial Nuclear Power 1991: Prospects for the United States and the World, DOE/EIA-0438(91) (Washington, DC, August 1991).

Figure 3. U.S. Average Annual Uranium Enrichment Service Requirements, 1991-2030

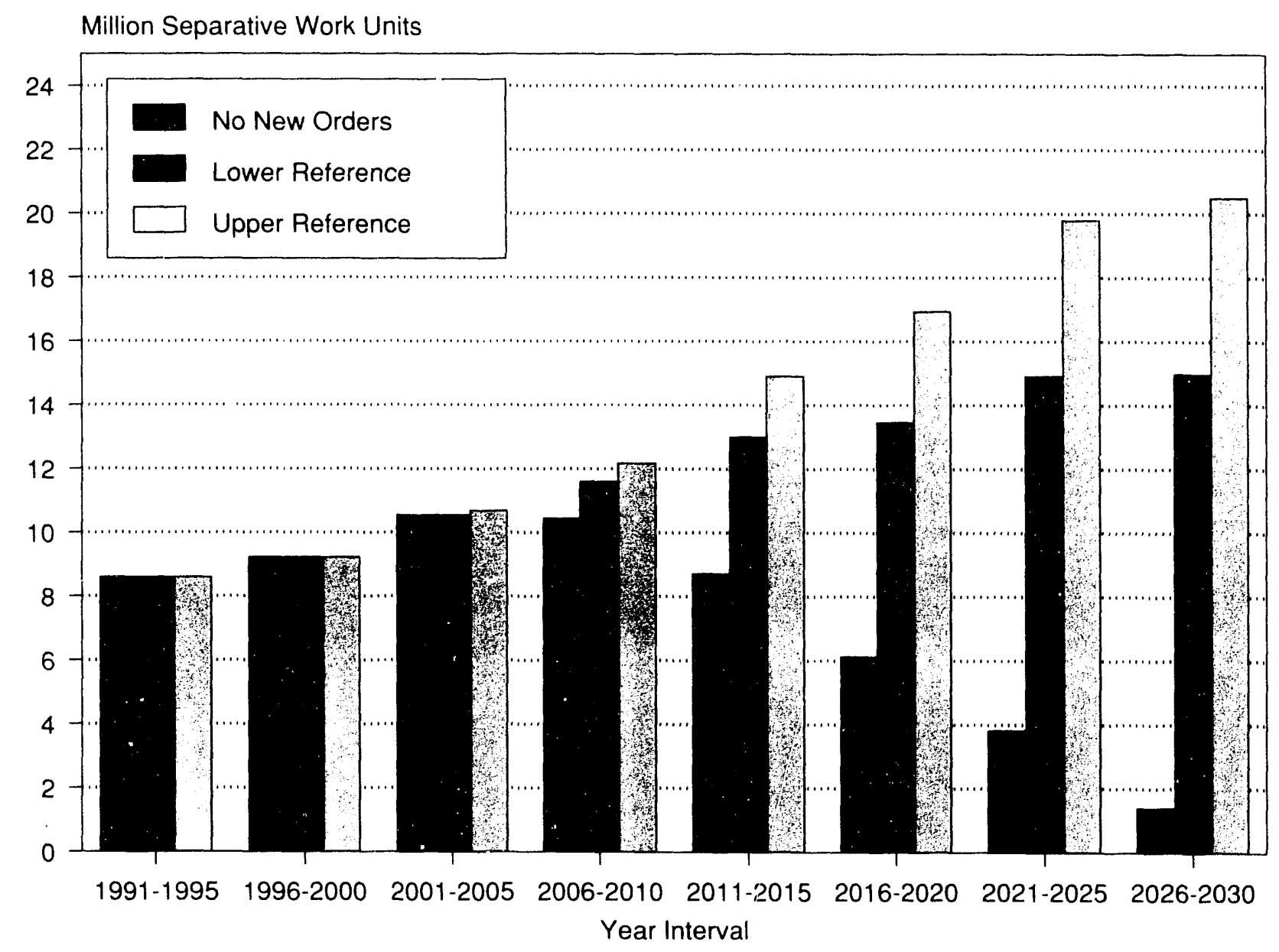

Source: Projected uranium enrichment requirements calculated using the International Nuclear Model, based on capacity projections from Energy Information Administration, Commercial Nuclear Power 1991: Prospects for the United States and the World, DOE/EIA-0438(91) (Washington, DC, August 1991). 


\section{Spent Fuel Discharges}

Average annual projections of spent fuel discharges for the three basic scenarios are presented in Table 5 and in Figure 4. Projections of the total discharges since 1957 are shown in Table 6 and Figure 5. Annual projections of spent fuel discharges represent the spent fuel discharged from reactors whose fuel cycle ended during the year, excluding discharged fuel that is scheduled for reinsertion. Therefore, the annual projections do not increase each year as would be expected if all reactors operated on a 12-month cycle. From 1979 through 1985, the length of the fuel cycle for most domestic reactors was 15 to 21 months. In these projections, all reactors are assumed to have approximately 18-month fuel cycles as the design burnups increase. (An alternative to increasing the length of the cycle would be to replace a smaller fraction of the core at each refueling.)

The average annual discharges in the Upper Reference case in 2016 through 2020 are projected to be at 2.4 compared to the 1991 through 1995 discharge levels of 2.0 thousand metric tons of initial heavy metal (Table 5). By the years 2026 through 2030 annual spent fuel discharges under the No New Orders case will drop to 0.6 thousand metric tons compared to 3.0 thousand metric tons for the Upper Reference case. The total amount of spent fuel discharged (in thousand metric tons of initial heavy metal) is projected in the Upper Reference case to grow to 31.6 in 1995 , to 41.3 in the year 2000, and 111.1 in the year 2030 (Table 6 and Figure 5). Through the year 2005, the projections in the different cases are the same. After 2005, the projections begin to diverge until the total amount of spent fuel discharged in the Upper Reference case in the year 2030 is 9.2 percent greater than the Lower Reference case, and the total spent fuel in the No New Orders case is 16.0 percent less than the Lower Reference case.

\section{Sensitivity Analyses}

The objective of the sensitivity analyses is to provide a range of outcomes based on alternative input assumptions. The sensitivity cases are selected as likely alternative future values for the assumptions used in the base case scenarios. Seven sensitivity studies were developed from the Lower Reference case (Table 7) and the same seven sensitivity cases were also developed for the No New Orders case (Table 8). The seven sensitivity cases are:

- Capacity factors in the equilibrium cycle are approximately 64 percent from 1991 through 2030.
- Capacity factors in the equilibrium cycle increase to 69 percent by 1998 and 75.0 percent by 2030 .

- The enrichment tails assay is 0.2 percent in each year.

- The enrichment tails assay is 0.3 percent in each year.

- No increase in design burnup occurs beyond 1991 levels.

- The design burnup increases at an accelerated pace and increases to 46,000 MWDT/MTIHM for boiling-water reactors in 2015 and to 60,000 MWDT/MTIHM for pressurized-water reactors in 2013.

- Plant operating licenses are renewed to 60 years for 70 percent of installed capacity for the No New Orders case and no license renewal is assumed in the Lower Reference case (i.e., a 40year life for reactors in the Lower Reference case).

\section{Capacity Factors}

The overall average capacity factor (utilization rate) achieved by U.S. nuclear units in 1990 reached 66.1 percent, which is 3.9 percentage points more than the 1989 value and the highest in the history of the industry. This was the third consecutive year that nuclear performance was notably above a consistent level of about 57 percent experienced during the period from 1979 through 1987. This general improvement in plant performance has a number of causes. Among the causes is the greater emphasis and expenditures on plant maintenance. Along with that is a gradual shift to longer fuel cycles, better operator training, improved instrumentation and control systems and fewer units in the historically lowperforming first fuel cycle. Most of the operational changes have been made over several years and their individual effects on capacity factor cannot be distinguished, but the results are expected to be longterm.

In the low-capacity-factor sensitivity study, the annual equilibrium cycle capacity factors are kept at approximately 64 percent from 1991 through 2030. In the high-capacity-factor study, the equilibrium-cycle capacity factors increase to 69 percent by 1998 and to 75 percent by 2020 . There is some variation in the capacity factors from year-to-year however. 
Table 5. Projected Average Annual Spent Fuel Discharges from U.S. Nuclear Power Plants, 1991-2030 (Thousand Metric Tons of Initial Heavy Metal)

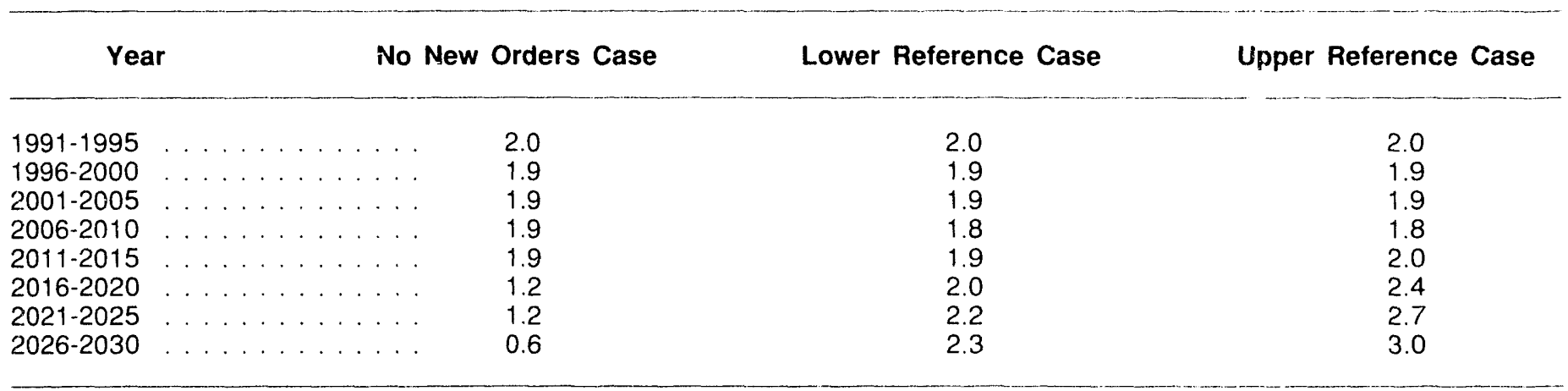

Source: Projected spent fuel discharges calculated using the International Nuclear Model, based on capasity projections from Energy Information Administration, Commercial Nuclear Power 1991: Prospects for the United States and the World, DOE/EIA-0438(91) (Washington, DC, August 1991).

Figure 4. U.S. Average Nuclear Spent Fuel Discharges, 1991-2030

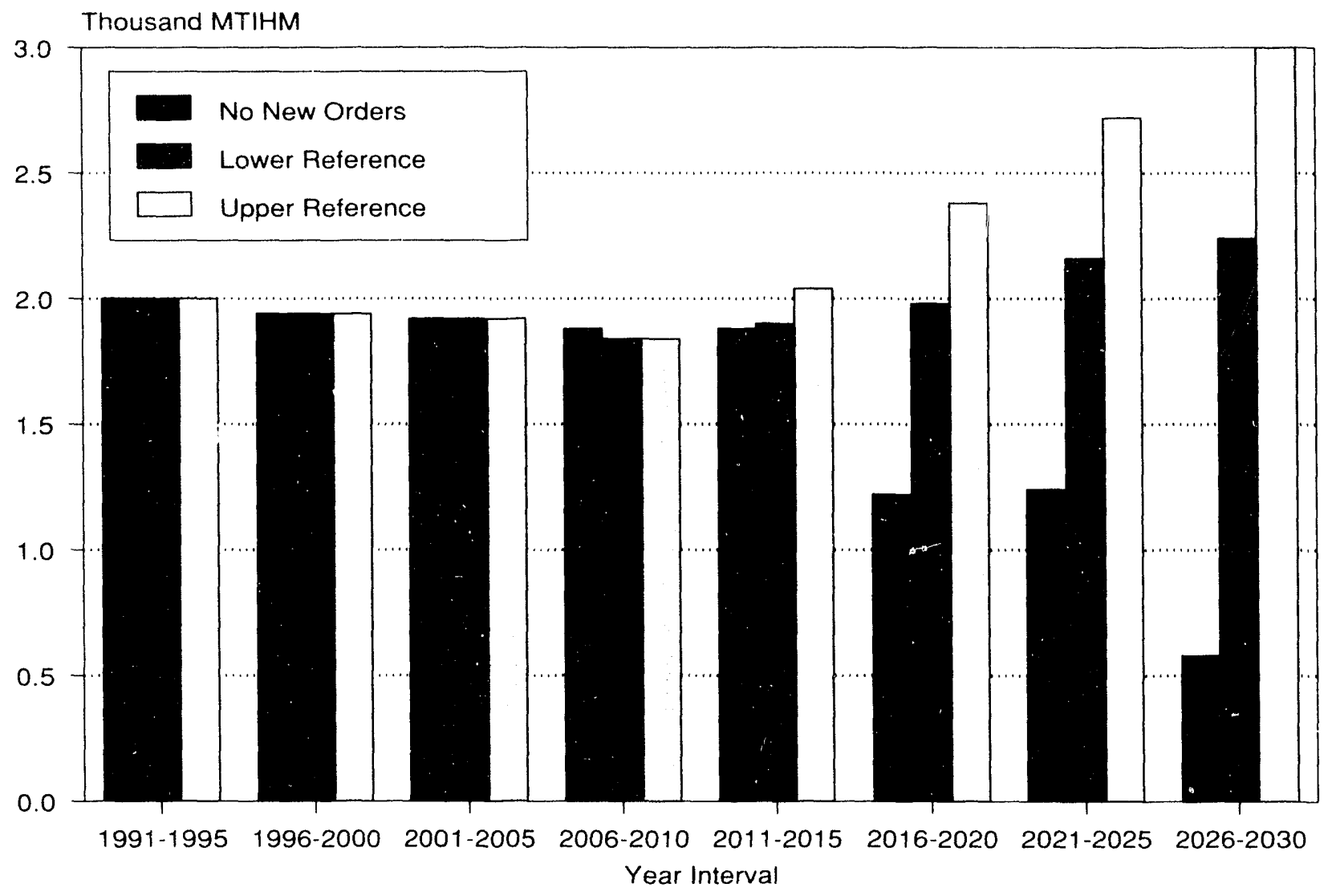

Source: Projected fuel-cycle requirements calculated using the International Nuclear Model, based on capacity projections from Energy Information Administration, Commercial Nuclear Power 1991: Prospects for the United States and the World, DOE/EIA-0438(91) (Washington, DC, August 1991). 
Table 6. Projected Cumulative Spent Fuel Discharges From U.S. Nuclear Power Plants: Total From 1957 (Thousand Metric Tons of Initial Heavy Metal)

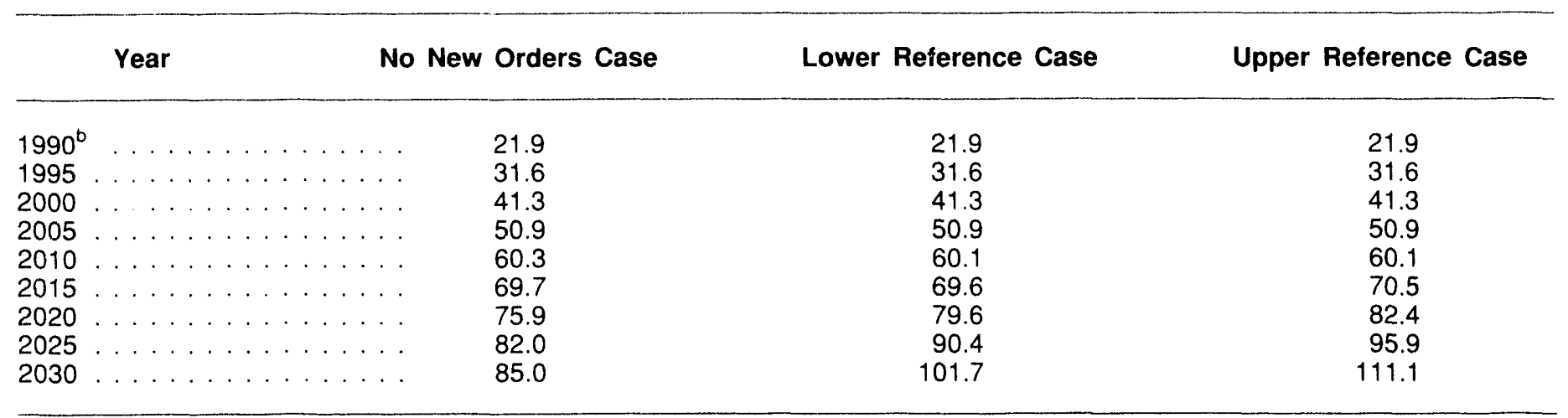

\footnotetext{
${ }^{a}$ Total spent fuel discharges include all discharges since 1957 that were not reprocessed by the U.S. Government and are not scheduled for reinsertion (1957 was the inception of commercial nuclear power in the United States).

"Data collected on Form RW-859, "Nuclear Fuel Data" (1989), indicate that 21.9 thousand metric tons of initial heavy metal are in storage as of Denember 31, 1990. The 21.9 thousand metric tons of initial heavy metal in storage do not include irradiated nuclear fuel that was reprocessed by the U.S. Government or that will be reinserted in future cycles of the nuclear reactors.

Source: Projected spent fuel discharges calculated using the International Nuclear Model, based on capacity projections from Energy Information Administration, Commercial Nuclear Power 1991: Prospects for the United States and the World, DOE/EIA-0438(91) (Washington, DC, August 1991).
}

In general, lower capacity factors decrease both uranium and enrichment services requirements. Spent fuel discharges are also reduced from lower capacity factors. For example, in the 2006 through 2010 year span, the projected average annual $\mathrm{U}_{3} \mathrm{O}_{4}$ and enrichment service requirements for the low capacity factor scenario are 7.7 and 3.4 percent less, respectively, than for the Lower Reference case, and both are 6.6 percent less in the 2016 through 2020 year period. Average annual spent fuel discharges decline throughout the entire projection period, decreasing by 1.0 percent in 1996 through 2000 and by 11.5 percent in 2026 through 2030 . Total spent fuel discharges are 3.0 percent less by 2020 and 5.0 percent less at the end of 2030. In the high capacity factor case, there is virtually no change from the Lower Reference case in average annual $\mathrm{U}_{3} \mathrm{O}_{8}$ and enrichment service requirements in 2006 through 2010. However, total uranium requirements increase 3.6 percent by the year 2010. The total spent fuel discharges are 1.9 percent higher by 2020. Similar differences result when the nuclear supply of the No New Orders case is used for the sensitivity cases.

\section{Enrichment Tails Assay}

Current enrichment contracting options allow utilities to specify the transaction tails assay under which natural uranium is enriched. The tails assay can be typically specified over a range of 0.20 to 0.30 percent U-235. The tails assay specifications do not affect the amount of spent fuel discharged. However, within the 0.20 to 0.30 percent range, the average tails assay specification affects the enrichment separative work requirements and the natural uranium enrichment feed requirements significantly. For example, a tails assay of 0.20 percent increases the average annual uranium enrichment service requirements by 24.7 percent in the years 1991 through 1995. In general, higher tails assays connote higher uranium concentrate requirements and lower separative work requirements to produce a given quantity of enriched uranium fuel and lower tails assay connote lower uranium requirements and higher separative work requirements. Thus, there is a natural flexibility, or tradeoff, between the requirements for natural uranium and enrichment requirements, depending on the tails assay selected. Under the assumption that the average tails assay selected by the utilities is largely dependent on the relative prices of natural uranium and separative work, utilities will specify tails assays that minimize the cost of enriched fuel.

The tails assays assumptions for the three basic nuclear supply scenarios are:

$\begin{array}{ll}1991 \text { through } 2000 & 0.30 \text { percent } \\ 2001 & 0.29 \text { percent } \\ 2002 & 0.28 \text { percent } \\ 2003 & 0.27 \text { percent } \\ 2004 & 0.26 \text { percent } \\ 2005 \text { through } 2030 & 0.25 \text { percent }\end{array}$

The higher tails assay sensitivity case specifies a 0.30 percent transaction tails assay for the entire projection period. The lower tails assay sensitivity case 
Figure 5. U.S. Total Nuclear Spent Fuel Discharges, 1970-2030

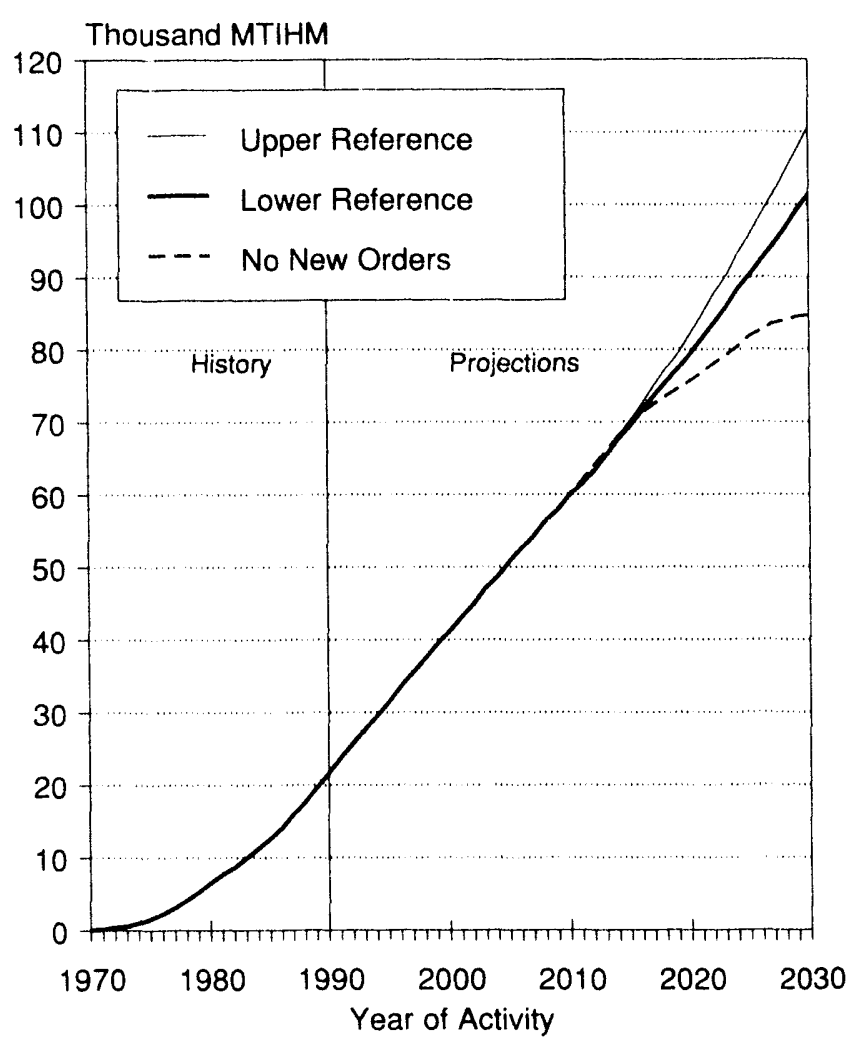

Source: Projected fuel-cycle requirements calculated using the International Nuclear Model, based on capacity projections from Energy Information Administration, Commercial Nuclear Power 1991: Prospects for the United States and the World, DOE/EIA-0438(91) (Washington, DC, August 1991).

represents a reversion to the historical 0.20 percent average tails assay. The changes in uranium requirements and separative work requirements due to the adjustments in tails assay (after 1990) are shown in Table 7 and Table 8.

Average annual uranium requirements for the lower tails assay sensitivity case of the Lower Reference decrease by 17.2 percent in the years 1991 through 1995, and they continue to decrease throughout the projection period, leveling at an 8.7 percent decrease in 2016 through 2030 . On the other hand, enrichment service requirements increase by 24.7 percent in the period 1991 through 1995 and about 12.0 percent for the 2016-2030 period for the lower tails assay sensitivity case. The No New Orders supply scenario shows similar results in uranium and enrichment services requirements when the tails assay assumption is changed. Spent fuel discharges are not affected by tails assay options.

\section{Fuel Burnup Levels}

Some electric utilities have been increasing the burnup of their nuclear fuel with indications that they plan to continue increasing burnup in the future. The major incentives for high burnup are reduced fuel cost, improved economics with longer cycles, and reduced number of discharged spent fuel assemblies. Burnup can be defined as the amount of energy produced per metric ton of enriched uranium. Figure 6 displays actual average equilibrium cycle burnup levels by year from 1972 through 1989 for boiling-water reactors. Also shown are projected average annual equilibrium cycle burnup values for the No New Orders case scenarios for 1991 through 2010. Figure 7 displays similar data for pressurized-water reactors.

The average discharge burnup for BWR's is projected to reach 35,000 MWDT / MTIHM by the year 2000 and 43,000 by the year 2000 for PWR's. Fuel use in boiling-water reactors tends to be in the lower end of the burnup range, whereas fuel used in pressurizedwater reactors tends to be in the upper end of the range. As a result of a successful cooperative effort between Government and industry, fuel with design burnup levels up to 45,000 MWDT/MTIHM for boiling-water reactors and 50,000 for pressurizedwater reactors is currently available from commercial vendors.

Increases in burnup are achieved by increasing the concentration of U-235 in the enriched uranium product and by changing the design specifications of the fuel rods to allow for longer in-core exposures. Increased burnup can result i I a smaller fraction of the core being replaced during refueling and the length of the operating cycle can also be increased. Up to a point, the total fuel costs decrease as burnup increases. The burnup level for achieving minimum cost is a function of design parameters and cost components of the fuel cycle. As noted above, utilities use higher fuel burnup to reduce fuel costs, increase cycle lengths, and reduce spent fuel generation. Increasing the cycle length means reducing the relative outage time: for example, an annual cycle requires three refuelings in a 3-year period, while an 18 -month cycle requires only two refuelings in 3 years. Theoretically, increased cycle lengths also imply improved capacity factors.

For all base case scenarios, the parameters associated with increases in design burnup are shown in Appendix B, Table B3. The average equilibrium cycle lengths were assumed to be approximately 18 months. 
Table 7. Sensitivity of Lower-Reference-Case Projections of U.S. Nuclear Fuel Cycle Requirements to Alternative Assumptions

Percent Differences from Lower-Reference Case Due to Variations in Assumptions

$\begin{array}{ccccccccc} & \text { Lower- } & \text { With } & \text { With } & \text { With } & \text { With } & \text { With No } & \text { With } \\ & \text { Reference- } & \text { Lower } & \text { Higher } & \text { Lower } & \text { Higher } & \text { Increase } & \text { Higher } & \text { With No } \\ & \text { Case } & \text { Capacity } & \text { Capacity } & \text { Tails } & \text { Tails } & \text { in Fuel } & \text { Fuel } & \text { License } \\ \text { Projection } & \text { Value } & \text { Factors } & \text { Factors } & \text { Assay } & \text { Assay } & \text { Burnup } & \text { Burnup }\end{array}$

Average Annual Natural Uranium Requirements (million pounds $U_{3} O_{s}$ equivalent)

\begin{tabular}{|c|c|c|c|c|c|c|}
\hline 1991-1995 & 41.9 & 2.3 & -17.2 & 0.0 & -1.1 & 0.0 \\
\hline $1996-2000$ & 42.2 & 6.1 & -17.2 & 0.1 & 1.2 & 0.0 \\
\hline $2001-2005$ & 39.8 & 6.1 & -12.0 & 6.7 & 5.3 & 0.0 \\
\hline $2006-2010$ & 42.6 & 0.0 & -8.6 & 10.8 & 2.8 & -1.7 \\
\hline $2011-2015$ & 46.4 & 4.5 & -8.6 & 10.7 & 4.6 & -13.0 \\
\hline $2016-2020$ & 48.9 & 4.5 & -8.7 & 10.7 & 5.9 & -23.2 \\
\hline $2021-2025$ & 53.7 & 4.1 & -8.7 & 10.7 & 1.8 & -33. \\
\hline $2026-2030$ & 52.1 & 7.3 & -8.7 & 10.8 & 6.3 & -47.5 \\
\hline
\end{tabular}

Total Natural Uranium Requirements from 1991 (million pounds $\cup_{3} O_{8}$ equivalent)

\begin{tabular}{|c|c|c|c|c|c|c|c|c|}
\hline 1995 & 209.2 & -1.2 & 2.3 & -17.2 & 0.0 & -1.1 & 0.5 & 0.0 \\
\hline 2000 & 420.2 & -0.6 & 4.2 & -17.2 & 0.1 & 0.1 & 0.7 & 0.0 \\
\hline 2005 & 619.1 & -1.0 & 4.8 & -15.5 & 2.2 & 1.8 & -0.2 & 0.0 \\
\hline 2010 & 832.2 & -2.8 & 3.6 & -13.7 & 4.4 & 2.0 & -0.5 & -0.4 \\
\hline 2015 & $1,064.2$ & -4.1 & 3.8 & -12.6 & 5.8 & 2.6 & -0.3 & -3.2 \\
\hline 2020 & $1,308.7$ & -4.5 & 3.9 & -11.9 & 6.7 & 3.2 & -0.8 & -6.9 \\
\hline 2025 & 1.577 .0 & -6.0 & 4.0 & -11.3 & 7.4 & 3.0 & -0.9 & -11. \\
\hline 2030 & $1,837.5$ & -6.2 & 4.4 & -11.0 & 7.9 & 3.4 & -1.1 & \\
\hline
\end{tabular}

Average Annual Uranium Enrichment Service Requirements (million separative work units)

\begin{tabular}{|c|c|c|c|c|c|c|c|c|}
\hline $1991-1995$ & 8.6 & 0.0 & 3.7 & 24.7 & 0.0 & -0.7 & 0.0 & 0.0 \\
\hline $1996 \cdot 2000$ & 9.2 & -0.8 & 4.7 & 24.3 & 0.0 & -1.5 & 1.1 & 0.0 \\
\hline $2001-2005$ & 10.5 & -6.2 & 7.1 & 16.8 & -5.7 & -6.1 & -1.0 & 0. \\
\hline $2006-2010$ & 11.6 & -3.4 & 0.4 & $12 !$ & -9.4 & -2.0 & -1.7 & -1. \\
\hline $2011-2015$ & 13.0 & -11.7 & -1.0 & 12.1 & -9.5 & -4.9 & 1.4 & 11.9 \\
\hline $2016-2020$ & 13.5 & -6.6 & 4.0 & 12.1 & -9.4 & -2.4 & -0.8 & 23 \\
\hline $2021-2025$ & 14.9 & -13.9 & 3.7 & 12.0 & -9.4 & -5.1 & 1.0 & -32. \\
\hline $2026-2030$ & 15.0 & -9.8 & 11.5 & 12.0 & -9.3 & -1.7 & 0.6 & -47.2 \\
\hline
\end{tabular}

Average Annual Spent Fuel Discharges (thousand metric tons of initial heavy metal)

\begin{tabular}{|c|c|c|c|c|c|c|c|c|}
\hline $1991-1995$ & 2.0 & 0.0 & 2.0 & 0.0 & 0.0 & 0.0 & 0.0 & 0.0 \\
\hline $1996-2000$ & 1.9 & -1.0 & 6.2 & 0.0 & 0.0 & 1.0 & 0.0 & 0.0 \\
\hline 2001-2005 & 1.9 & -2.1 & 0.0 & 0.0 & 0.0 & 6.2 & -2.1 & 0.0 \\
\hline $2006-2010$ & 1.8 & -6.5 & 1.1 & 0.0 & 0.0 & 16.3 & -9.8 & 2.2 \\
\hline $2011-2015$ & 1.9 & -5.2 & 3.1 & 0.0 & 0.0 & 29.2 & 2.1 & 11.6 \\
\hline $2016-2020$ & 2.0 & -10.1 & 3.0 & 0.0 & 0.0 & 23.2 & -4.0 & -12.1 \\
\hline $2021-2025$ & 2.2 & -12.0 & 3.7 & 0.0 & 0.0 & 26.9 & -6.5 & -12.0 \\
\hline $2026-2030$ & 2.3 & -11.5 & 0.9 & 0.0 & 0.0 & 26.5 & -7.1 & -36.3 \\
\hline
\end{tabular}

Cumulative Spent Fuel Discharges from 1957 (thousand metric tons of initial heavy metal)

\begin{tabular}{|c|c|c|c|c|c|c|c|c|}
\hline 1995 & 31.6 & 0.0 & 0.6 & 0.0 & 0.0 & 0.0 & 0.0 & 0.0 \\
\hline 2000 & 41.3 & -0.2 & 2.2 & 0.0 & 0.0 & 0.2 & -0.2 & 0.0 \\
\hline 2005 & 50.9 & -0.8 & 1.6 & 0.0 & 0.0 & 1.6 & -0.6 & 0 \\
\hline 2010 & 60.1 & -1.5 & 1.5 & 0.0 & 0.0 & 3.8 & -2.0 & \\
\hline 2015 & 69.6 & -1.9 & 1.9 & 0.0 & 0.0 & 7.3 & -1.3 & 1. \\
\hline 2020 & 79.6 & -3.0 & 1.9 & 0.0 & 0.0 & 9.2 & -1.8 & \\
\hline 2025 & 90.4 & -4.1 & 2.1 & 0.0 & 0.0 & 11.4 & -2.3 & \\
\hline 2030 & 101.7 & -5.0 & 2.0 & 0.0 & 00 & 13.1 & -2.9 & \\
\hline
\end{tabular}

Source: Projected fuel cycle requirements calculated using the International Nuclear Model, based on capacity projections from Energy Information Administration, Commercial Nuclear Power 1991: Prospects for the United States and the World, DOE/EIA-0438(91) (Washington, DC, August 1991). 
Table 8. Sensitivity of No-New-Orders-Case Projections of U.S. Nuclear Fuel Cycle Requirements to Alternative Assumptions

Percent Differences from No New Orders Case Due to Variations in Assumptions

$\begin{array}{ccccccccc} & \text { No-New- } & \text { With } & \text { With } & \text { With } & \text { With } & \text { With No } & \text { With } \\ & \text { Orders- } & \text { Lower } & \text { Higher } & \text { Lower } & \text { Higher } & \text { Increase } & \text { Higher } & \text { With } \\ & \text { Case } & \text { Capacity } & \text { Capacity } & \text { Tails } & \text { Tails } & \text { in Fuel } & \text { Fuel License } \\ \text { Projection } & \text { Value } & \text { Factors } & \text { Factors } & \text { Assay } & \text { Assay } & \text { Burnup } & \text { Burnup }\end{array}$

Average Annual Natural Uranium Requirements (million pounds $U_{3} \mathrm{O}_{8}$ equivalent)

\begin{tabular}{|c|c|c|c|c|c|c|c|c|c|}
\hline $1991-1995$ & . . & 41.8 & -1.2 & 2.3 & -17.2 & 0.0 & -1.1 & 0.5 & 0.0 \\
\hline $1996-2000$ & . & 42.2 & 0.0 & 6.1 & -17.2 & 0.1 & 1.2 & 0.8 & 0.0 \\
\hline 2001-2005 & . & 39.4 & -1.2 & 7.1 & -12.0 & 6.7 & 6.3 & -1.1 & 0.0 \\
\hline $2006-2010$ & . & 38.3 & -7.6 & 1.4 & -8.7 & 10.8 & 2.0 & -0.9 & 1.9 \\
\hline $2011-2015$ & . & 30.0 & -11.3 & 5.7 & -8.7 & 10.8 & 0.7 & -4.2 & 19.7 \\
\hline $2016-2020$ & . & 21.7 & -0.3 & 3.0 & -8.6 & 10.9 & 6.0 & -3.0 & 46.9 \\
\hline $2021-2025$ & . & 13.8 & -11.4 & 10.0 & -8.7 & 11.0 & 1.9 & 0.3 & 123.4 \\
\hline $2026-2030$ & . . & 3.6 & -6.1 & 20.4 & -9.4 & 9.9 & 5.0 & -6.6 & 701.1 \\
\hline
\end{tabular}

Total Natural Uranium Requirements from 1991 (million pounds $U_{3} O_{8}$ equivalent)

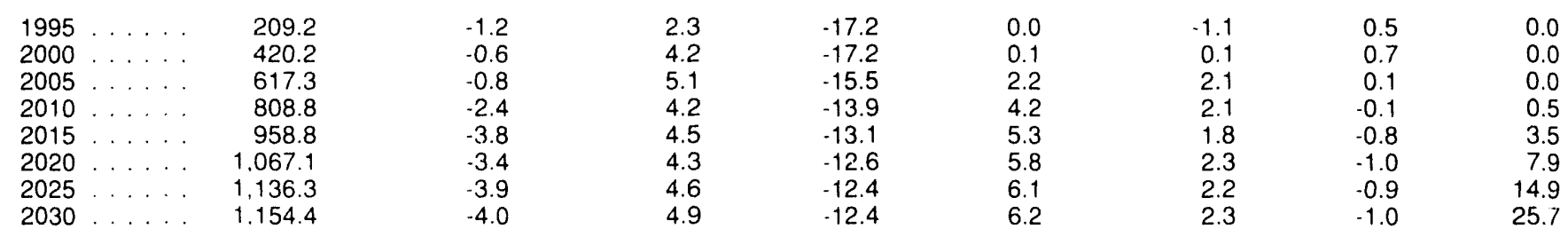

Average Annual Uranium Enrichment Senvice Requirements (million separative work units)

\begin{tabular}{|c|c|c|c|c|c|c|c|c|}
\hline 1991-1995 & 8.6 & 0.0 & 3.7 & 24.7 & 0.0 & -0.7 & 0.0 & 0.0 \\
\hline $1996-2000$ & 9.2 & -0.8 & 4.7 & 24.3 & 0.0 & -1.5 & 1.1 & 0.0 \\
\hline $2001-2005$ & 10.5 & -6.2 & 7.1 & 16.8 & -5.7 & -6.7 & -1.2 & 0.0 \\
\hline $2006-2010$ & 10.4 & -1.5 & 3.0 & 12.0 & .9 .4 & 0.5 & 0.3 & 1.9 \\
\hline $2011-2015$ & 8.7 & .11 .8 & -1.1 & 12.0 & -9.3 & -10.3 & 0.2 & 17.6 \\
\hline $2016-2020$ & 6.1 & -3.6 & 10.5 & 12.0 & -9.4 & -6.6 & -4.3 & 45.5 \\
\hline $2021-2025$ & 3.8 & -2.5 & 14.0 & 11.9 & -9.3 & 4.5 & 7.8 & 121.4 \\
\hline $2026-2030$ & 1.4 & .20 .7 & 3.8 & 11.9 & -9.3 & -14.2 & -10.2 & 510.4 \\
\hline
\end{tabular}

Average Annual Spent Fuel Discharges (thousand metric tons of initial heavy metal)

\begin{tabular}{|c|c|c|c|c|c|c|c|c|}
\hline $1991-1995$ & 2.0 & 0.0 & 2.0 & 0.0 & 0.0 & 0.0 & 0.0 & 0.0 \\
\hline $1996-2000$ & 1.9 & -1.0 & 6.2 & 0.0 & 0.0 & 1.0 & 0.0 & 0.0 \\
\hline $2001-2005$ & 1.9 & -2.1 & 0.0 & 0.0 & 0.0 & 6.2 & -2.1 & 0.0 \\
\hline $2006-2010$ & 1.9 & -5.3 & 1.1 & 0.0 & 0.0 & 16.0 & -8.5 & -3.2 \\
\hline $2011-2015$ & 1.9 & -3.2 & 4.3 & 0.0 & 0.0 & 23.4 & 1.1 & -9.6 \\
\hline $2016-2020$ & 1.2 & -3.3 & 4.9 & 0.0 & 0.0 & 24.6 & -4.9 & 19.7 \\
\hline $2021-2025$ & 1.2 & -8.1 & 3.2 & 0.0 & 0.0 & 14.5 & -4.8 & 17.7 \\
\hline $2026-2030$ & 0.6 & 6.9 & 10.3 & 0.0 & 0.0 & 17.2 & -3.4 & 131.0 \\
\hline
\end{tabular}

Cumulative Spent Fuel Discharges from 1957 (thousand metric tons of initial heavy metal)

\begin{tabular}{|c|c|c|c|c|c|c|c|c|}
\hline 1995 & 31.6 & 0.0 & 0.6 & 0.0 & 0.0 & 0.0 & 0.0 & 0.0 \\
\hline 2000 & 41.3 & -0.2 & 2.2 & 0.0 & 0.0 & 0.2 & -0.2 & 0.0 \\
\hline 2005 & 50.9 & -0.8 & 1.6 & 0.0 & 0.0 & 1.6 & -0.6 & 0.0 \\
\hline 2010 & 60.3 & -1.5 & 1.7 & 0.0 & 0.0 & 3.8 & -2.0 & -0.5 \\
\hline 2015 & 69.7 & -1.6 & 2.2 & 0.0 & 0.0 & 6.5 & -1.4 & -1.9 \\
\hline 2020 & 75.9 & -1.8 & 2.1 & 0.0 & 0.0 & 7.6 & -1.8 & -0.1 \\
\hline 2025 & 82.0 & -2.1 & 2.6 & 0.0 & 0.0 & 8.3 & -1.8 & 1.2 \\
\hline 2030 & 85.0 & -2.1 & 2.6 & 0.0 & 0.0 & 8.4 & -2.0 & 55 \\
\hline
\end{tabular}

Source: Projected fuel cycle requirements calculated using the International Nuclear Model, based on capacity projections from Energy Information Administration, Commercial Nuclear Power 1991: Prospects for the United States and the World, DOE/EIA-0438(91) (Washington, DC. August 1991). 
Figure 6. Average Equilibrium-Cycle Discharge Burnup for U.S. Boiling-Water Reactors, 1972-2010

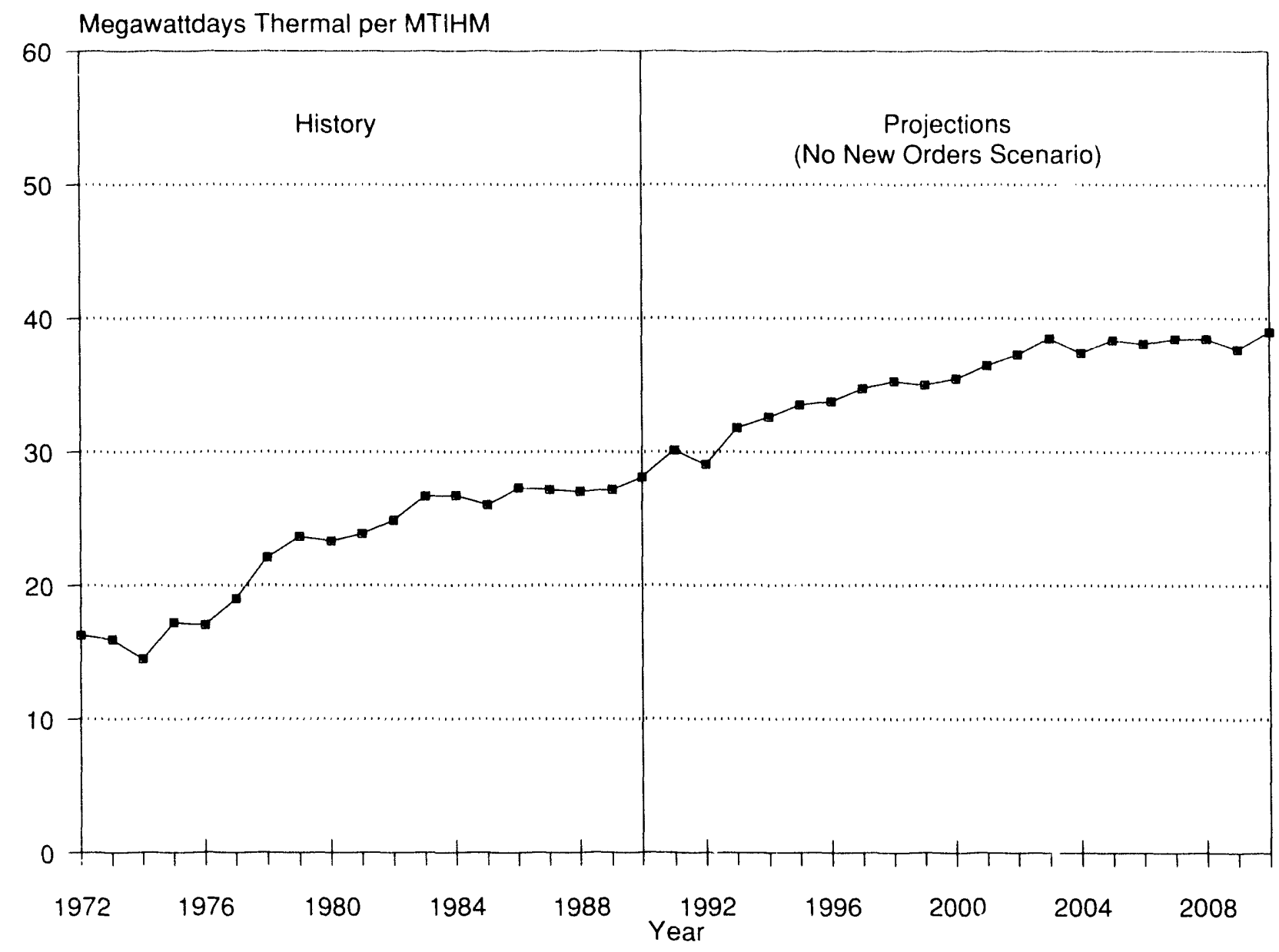

Sources: Projected average equilibrium-cycle discharge burnup calculated using the International Nuclear Model. Actual Data: Energy Information Administration, Form RW-859, "Nuclear Fuel Data" (1990). Projections: International Nuclear Model and Form RW-859, "Nuclear Fuel Data" (1990).

Lower and higher burnup sensitivity cases for the Lower Reference and No New Orders cases were analyzed. These cases provided a range within which projected spent fuel discharges should fall. In the lower burnup case, the design burnup level was assumed to remain constant at about 33,000 MWDT/ MTIHM for BW'R's and 40,000 MWDT/MTIHM for PWR's. In the higher burnup case, design burnup is increased more rapidly than in the base cases and design burnup is also increased further out in the projection period. For example, design burnup reaches about 46,000) MWDT/MTIHM for PWR's in 1997 compared to 1998 in the base case and about 50,000$)$ MWDT/MTIHM for PWR's in 20(02 compared to 2003 in the base case. Design burnup will increase to 46,000 MWDT/MTIHM in 2010 and beyond for BWR's and to 60,000) MWDT/MTIHM in 2010 and beyond for PWR's.
In the Lower Reference Case, higher burnup decreases total uranium requirements by 1.1 percent through 2030. Higher burnup decreases total spent fuel discharges by 2.9 percent from the Lower Reference Case over the projection period. Similar results occur for higher burnup sensitivity in the No New Order case. In the no increase in fuel burnup scenario, the speni fuel inventory becomes greater than in the Lower and No New Orders base cases by the year 2000 and is projected to be 13.1 percent and 8.4 percent higher, respectively, by 2030 .

Reduction in the expected fuel burnup also affects the requirements for natural uranium and for enrichment service. For example, when lower burnup is assumed,

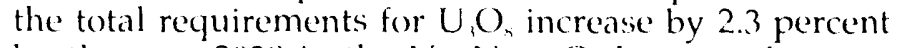
by the year 2030 in the No New Orders case because the reactors are less efficient in their fued utilization. 
Figure 7. Average Equilibrium-Cycle Discharge Burnup for U.S. Pressurized-Water Reactors, 1972-2010

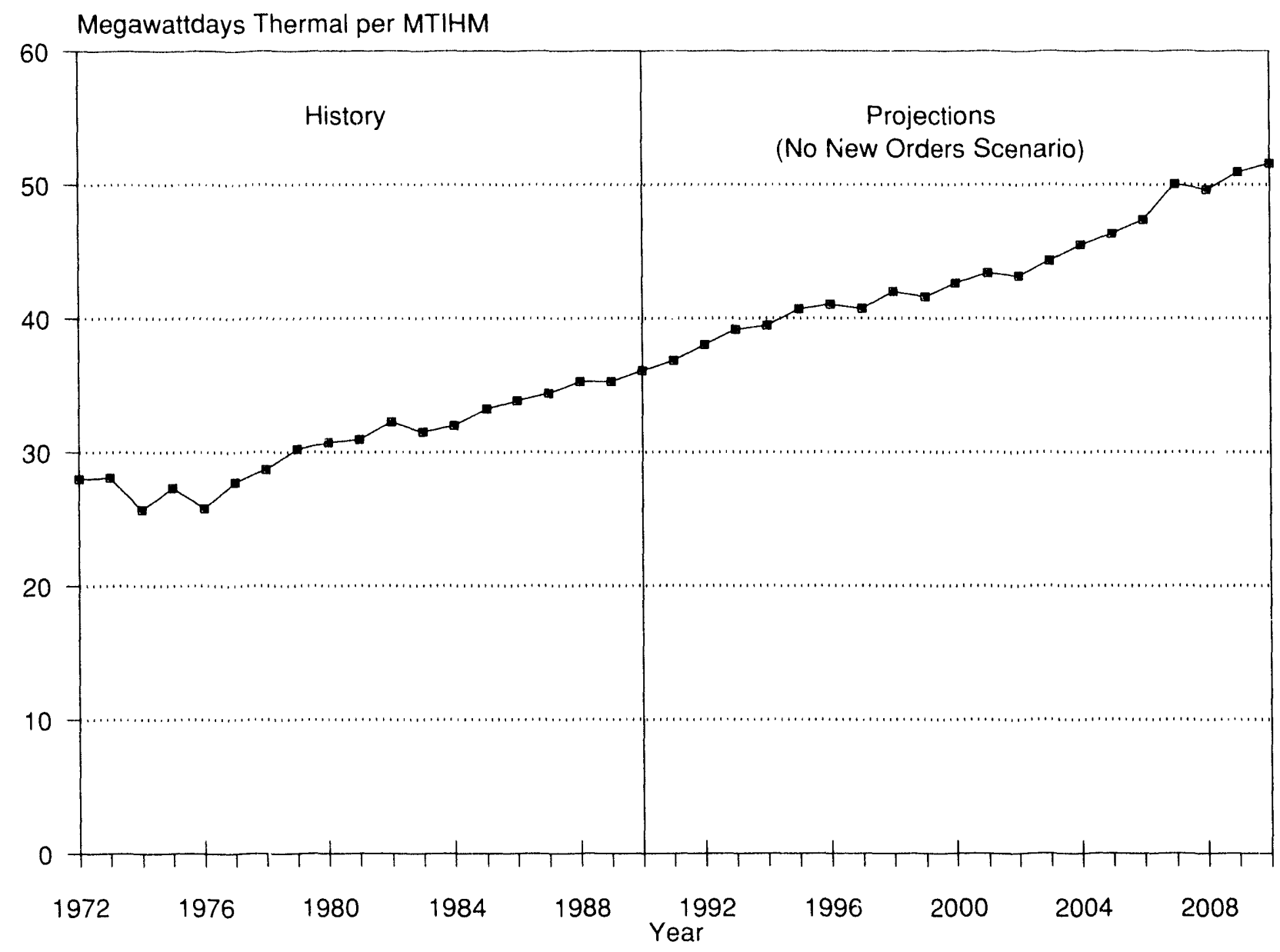

Sources: Projected average equilibrium-cycle discharge burnup calcuiated using the International Nuclear Model. Actual Data: Energy Information Administration, Form RW-859, "Nuclear Fuel Data" (1990). Projections: International Nuclear Model and Form RW-859, "Nuclear Fuel Data" (1990).

\section{Plant Life Expectancy}

The No New Orders case assumes a uniform plant life of 40 years. In the Upper and Lower basic scenarios, which represent nuclear capacity growth cases compared to the No New Orders case, the operating license is renewed for an additional 20 years for 70 percent of the existing operational capacity. When the assumption of a 60 year plant life expectancy is reduced to 40 years in the Lower Reference case, uranium requirements drop significantly. Average annual requirements decrease by 13 percent in 2011 through 2015 and continue to decline reaching a 47.5 percent decrease in 2026 through 2030. Total uranium requirements are reduced 16.6 percent by 2030 . This is to be expected because a reduction in plant life implies a reduction in installed capacity. Average annual spent fuel discharges decrease significantly reaching a reduction of 36.3 percent by 2026 through 2030 . Total spent fuel discharges decrease by 5.2 percent by 2030. For the No New Orders case, extended license renewal increases total uranium requirements 25.7 percent by 2030 and spent fuel discharges increase 5.5 percent by 2030. Here again, this is to be expected because installed nuclear capacity increases with longer plant life. 


\section{Projections of Nuclear Fuel Cycle Requirements for the Free Market Economies}

This chapter presents projections of nuclear fuel cycle requirements-both uranium concentrate $\left(\mathrm{U}_{3} \mathrm{O}_{8}\right)$ and uranium enrichment services-and spent fuel discharges for each of the five groups of countries that constitute the Free Market Economies (FME), as well as the FME total. These projections are basi'd on the projections of domestic nuclear power plant capacity that were presented in Chapter 2 and projections of foreign capacity.

For these projections, the FME countries are aggregated as follows:

- The United States

- Canada

- Europe (Belgium, Finland, France, Italy, the Netherlands, Spain, Sweden, Switzerland, the United Kingdom, West Germany, and Yugoslavia)

- The Far East (Japan, South Korea, and Taiwan)

- Other countries (Argentina, Brazil, India, Mexico, Pakistan, and South Africa)

- Total FME.

Projections of FME commercial nuclear power capacity for various groups of countries are listed in Table 9. By the end of 1990, 243 nuclear reactors representing 179.8 net GWe, were operable in the FME countries, excluding the United States. Another 59 reactors, totaling 54.4 net GWe, were in the construction pipeline. The projections of nuclear capacity in foreign FME countries in the year 2010 range from 223.7 net GWe in the Lower Reference case to 284.2 net GWe in the Upper Reference case. The basic assumptions used for the projections are as follows:

- Capacity factors range from 69 percent to 71 percent during the projection period. This is an average for all FME countries (including the United States).
- Enrichment tails assay for light-water reactors is kept constant at 0.25 percent for the projection period (excluding the United States, which was noted above).

- Design burnup for nuclear units in Europe and the Far East goes from about 33,000 MWDT/ MTIHM in 1991 to $43,000 \mathrm{MWDT} / \mathrm{MTIHM}$ in 2004 and beyond for boiling-water reactors, and from about 35,000 MWDT/MTIHM in 1991 to 50,000 MWDT/MTIHM in 2004 and beyond for pressurized-water reactors. Appendix B shows specific design burnup assumptions by year and other important factors about the fuel plans.

- Plants are retired after 30 years of operation.

These assumptions differ from those used for the United States for the following reasons. Capacity factors and design burnup assumptions are based on analyses of trends in the historical data for domestic and foreign reactors. Assumptions regard;, the enrichment tails assay for domestic reactors are also based on historical data; however, no similar historical data are available at this time for foreign reactors. Judgmental, the midpoint between 0.20 and 0.30 percent was selected for the enrichment tails assay for FME reactors. Plant life for domestic ruactors is based on the operating license period established by the U.S. Nuclear Regulatory Commission. In order to have a common assumption for the other FME countries, it was decided to use a 30-year operating life, which coincides with the conventional 30-year economic life assumption.

At the end of 1990, reactors in countries other than the United States accounted for about 64 percent of the total FME commercial nuclear capacity. About 80 percent of this foreign capacity consisted of lightwater reactors; the remainder of the capacity consisted of gas-cooled reactors, advanced gas-cooled reactors, pressurized heavy-water reactors, and fast breeder reactors. The light-water reactors require periodic refueling. The gas-cooled reactors, which are primarily

'The Socialist Federal Republic of Yugoslavia participates in certain work of the Organization for Economic Cooperation and Development (agreement of October 28, 1961). 
Table 9. Projected Capacity of Foreign Nuclear Power Plants in the Free Market Economies, 1995-2010

(Net GWe)

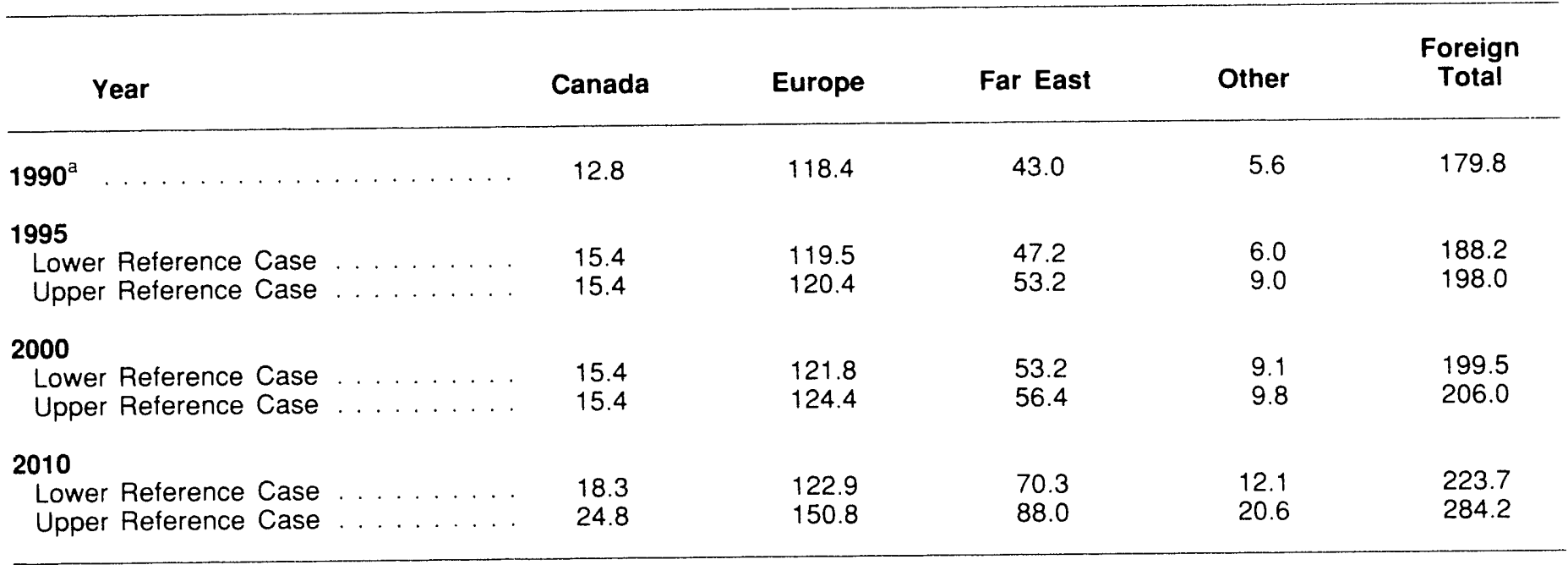

${ }^{a}$ Actual data

Note: Totals may not equal sum of components due to independent rounding.

Source: Energy Information Administration, Commercial Nuclear Power 1991: Prospects for the United States and the World, DOE/EIA-0438(91) (Washington, DC, August 1991).

in the United Kingdom, and pressurized heavy-water reactors, which are primarily in Canada, have on-line refueling capability. The results presented in this chapter account for the different fuelcycle requirements of each reactor type represented in FME countries. It is important to note that the base case fuel cycle requirements (i.e., uranium concentrate requirements and separative work requirements) do not account for the use of recycled uranium. In other words, the projections show uranium requirements without differentiating as to the source of the uranium. The United Kingdom has been reprocessing spent fuel and it is estimated that some 70 percent of all advanced gas cooled reactors (AGR) fuel has been produced from this material. The base case fuel cycle requirements also do not account for the use of mixed oxide (MOX) fuel; however data on the use of MOX fuel are used to provide a sensitivity case later in this section.

\section{Uranium Concentrate Requirements}

Average annual requirements for $\mathrm{U}_{3} \mathrm{O}_{4}$ in the FME countries are expected to increase in the Upper
Reference case from 119.6 in the years 1991 through 1995 to 157.3 in the years 2006 through 2010, representing a 32 percent increase (Table 10 and Figure 8). During the same interval, the annual FME requirements for $\mathrm{U}_{3} \mathrm{O}_{x}$ are projected to increase by about 13 percent in the Lower Reference case. This projected growth in uranium requirements is less than the projected growth in nuclear capacity, due principally to the expected increase in nuclear fuel burnup.

The U.S. and Europe are projected to account for about 76 percent of the annual FME requirements for uranium in the near term, 1991 through 1995 declining to 69 percent is the years 2006 through 2010. By 2006 through 2010, the annual requirements for the Far East will increase by 39 percent, causing its share of annual FME requirements to increase to approximately 21 percent in the Lower Reference Case.

The spread between the Lower-Reference- and UpperReference-case projections of average annual $\mathrm{U}_{2} \mathrm{O}_{\mathrm{n}}$ requirements for the FME countries are projected to grow from less than 3 percent in 1991 through 1995 to 19 percent in 2006 through 2010. 
Table 10. Projected Average Annual Uranium Requirements for Nuclear Power Plants in the Free Market Economies, 1991-2010

(Million Pounds $\mathrm{U}_{3} \mathrm{O}_{8}$ Equivalent)

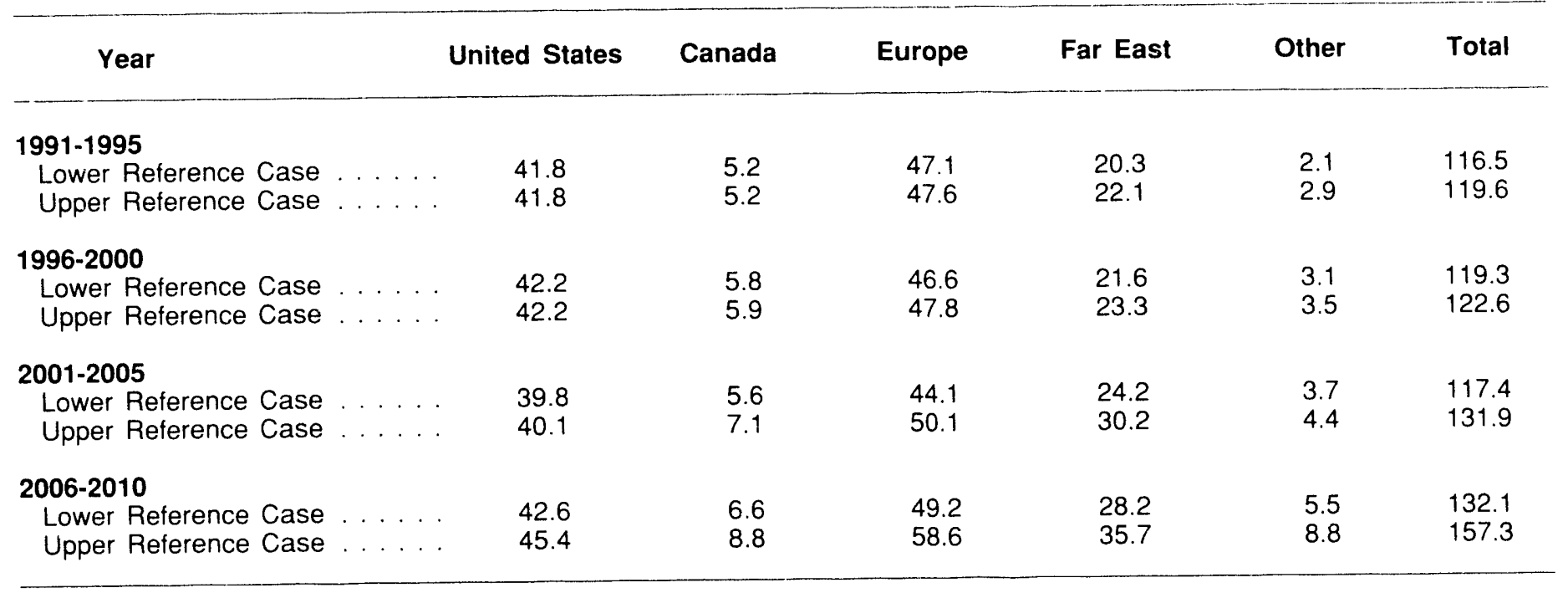

Note: Totals may not equal sum of components due to independent rounding.

Source: Projected uranium requirements calculated using the International Nuclear Model, based on capacity projections from Energy Information Administration, Commercial Nuclear Power 1991: Prospects for the United States and the World, DOE/EIA-0438(91) (Washington, DC. August 1991).

Total (cumulative) requirements for uranium in the FME countries are projected to increase from 582.3 million pounds in 1995 to about 2.4 billion pounds by the end of 2010 in the Lower Reference case (Table 11 and Figure 9). The difference between projected total FME requirements for uranium for the Upper and Lower Reference cases grows from less than 3 percent in 1995 to about 10 percent by 2010 . For the "other countries" group, the Upper Reference case is about 37 percent greater than the Lower Reference case in 2010 signifying a great deal of uncertainty between the 2 scenarios.

\section{Uranium Enrichment Service Requirements}

Average annual FME requirements for uranium enrichment services (SWU requirements) are projected to grow in the Upper Reference case from 25.9 million SWU in 1991 through 1995 to 37.8 million SWU in the years 2006 through 2010, an increase of 46 percent (Table 12 and Figure 10). The enrichment service requirements for the "other countries" group are expected to more than double over the same period. No enrichment service requirements are indicated for Canada, where only natural-uranium-fueled reactors are used. The U.S. Upper-Reference-case share of annual FME enrichment service requirements is projected to range between 32 and 34 percent through the forecast period. The European share of the annual enrichment service requirements is 44 percent of the average FME requirements for the Upper Reference case in the 1991 through 1995 period, and declines to about 39 percent in 2006 through 2010.

Current worldwide enrichment capacity (43.5 million separative work units, Table 13) is ample to meet the near-term demand for enriched uranium. Moreover, it appears that current capacity can also meet the demand through 2010. A modest increase in capacity is shown by 1995, going from 43.5 to 45.0 million separative work units. 
Figure 8. Average Annual Uranium Requirements for the Free Market Economies, 1991-2010

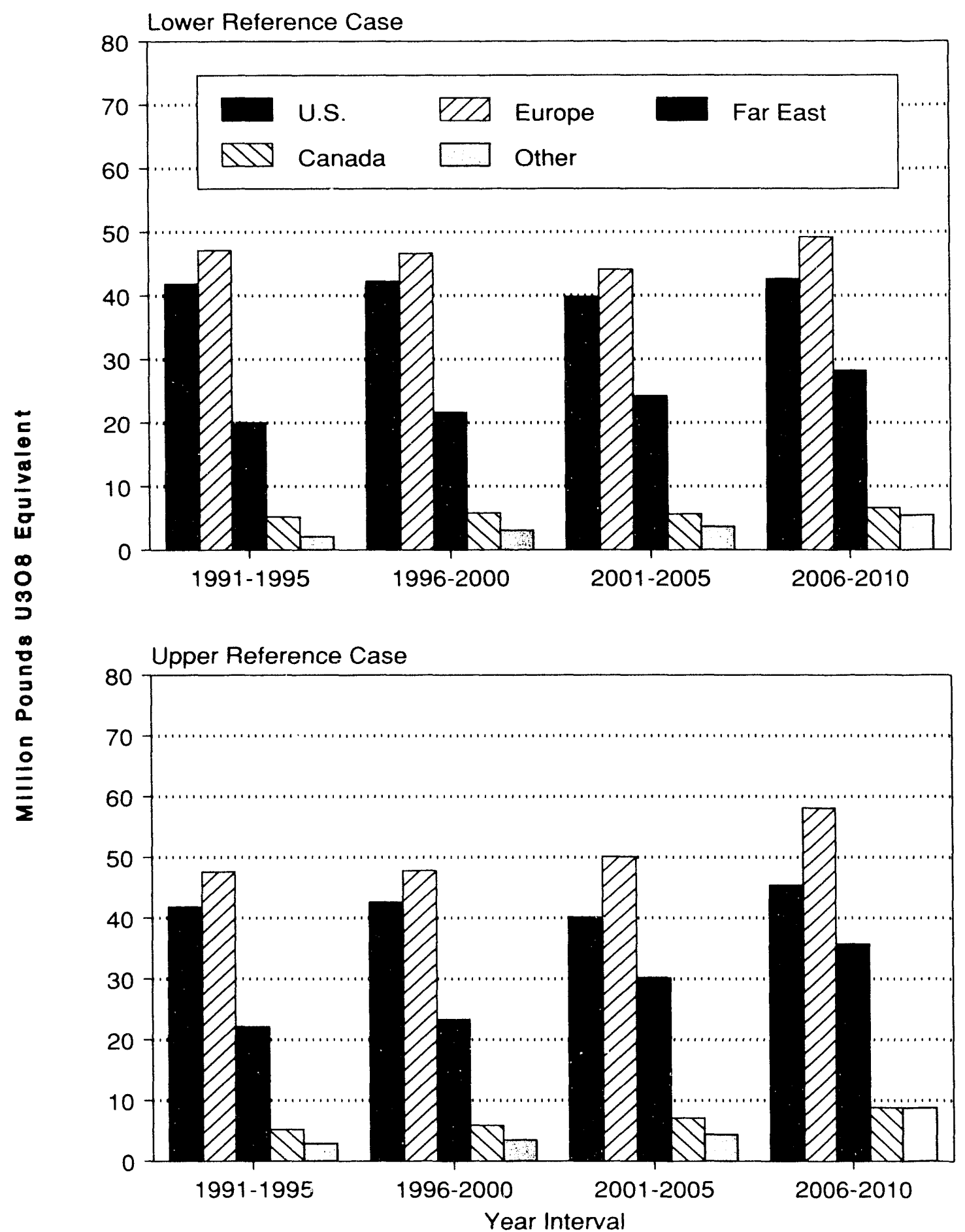

Source: Projected fuel-cycle requirements calculated using the International Nuclear Model, based on capacity projections from Energy Information Administration, Commercial Nuclear Power 1991: Prospects for the United States and the World, DOE/EIA-0438(91) (Washington, DC, August 1991). 
Table 11. Projected Cumulative Uranium Requirements for Nuclear Power Plants

in the Free Market Economies from 1991

(Million Pounds $\mathrm{U}_{3} \mathrm{O}_{8}$ Equivalent)

\begin{tabular}{|c|c|c|c|c|c|c|}
\hline Year & United States & Canada & Europe & Far East & Other & Total \\
\hline \multicolumn{7}{|l|}{1995} \\
\hline $\begin{array}{l}\text { Lower Reference Case } \\
\text { Upper Reference Case }\end{array}$ & $\begin{array}{l}209.2 \\
209.2\end{array}$ & $\begin{array}{l}25.9 \\
26.0\end{array}$ & $\begin{array}{l}235.5 \\
237.8\end{array}$ & $\begin{array}{l}101.4 \\
110.4\end{array}$ & $\begin{array}{l}10.3 \\
14.4\end{array}$ & $\begin{array}{l}582.3 \\
597.8\end{array}$ \\
\hline \multicolumn{7}{|l|}{2000} \\
\hline Lower Reference Case & 420.2 & 55.0 & 468.7 & 209.3 & 25.7 & $1,178.9$ \\
\hline Upper Reference Case & 420.2 & 55.3 & 476.7 & 227.1 & 31.7 & $1,211.0$ \\
\hline \multicolumn{7}{|l|}{2005} \\
\hline Lower Reference Case & 619.1 & 83.1 & 689.1 & 330.4 & 44.2 & $1,765.9$ \\
\hline Upper Reference Case & 620.7 & 90.7 & 727.0 & 378.2 & 53.7 & $1,870.3$ \\
\hline \multicolumn{7}{|l|}{2010} \\
\hline Lower Reference Case & 832.2 & 115.9 & 935.3 & $47 \div .3$ & 71.6 & $2,426.3$ \\
\hline Upper Reference Case & 847.9 & 134.7 & $1,019.9$ & 556.6 & 97.9 & $2,657.0$ \\
\hline
\end{tabular}

Source: Projected uranium requirements calculated using the International Nuclear Model, based on capacity projections from Energy Information Administration, Commercial Nuclear Power 1991: Prospects for the United States and the World, DOE/EIA-0438(91) (Washington, DC, August 1991).

\section{Spent Fuel Discharges}

The data show that the ararage annual spent fuel discharges are relatively stable over the projection period, averaging about 9.3 million pounds through the forecast period for the Lower Reference case (Table 14 and Figure 11).

Cumulative spent fuel discharges for FME countries in 1995 through 2010 are shown in Table 15. For the Lower Reference case, 183.8 thousand MTIHM are projected to be discharged from nuclear reactors between 1991 and 2010. Thirty-eight percent of that amount will be from European reactors, 23 percent from Canadian reactors, and 21 percent from U.S. reactors.

\section{Mixed Oxide Fuel Use}

This section of the report briefly examines the affect of mixed oxide fuel (MOX) use on the Lower Reference case for Europe and the Far East. MOX fuel refers to a mixture of reactor grade plutonium and either natural or depleted uranium (i.e., enrichment plant tailings depleted in U-235) to replace a fractir'n of the partially enriched uranium. The first use of MOX fuel in a pressurized water reactor was in the Belgium BR3 PWR in 1963. Since 1963 progress has been achieved in demonstrating the satisfactory properties of MOX fuel. The Federal Republic of Germany has manufactured and loaded more than 38,000 MOX thermal reactor fuel rods. Some 32,000 MOX fuel rods have been manufactured in Belgium and irradiated in LWR's. The manufacture and use of MOX fuel can be regarded as an established technology and the use of 30 percent MOX is now a reality in France." 
Figure 9. Cumulative Uranium Requirements for the Free Market Economies, 1991-2010

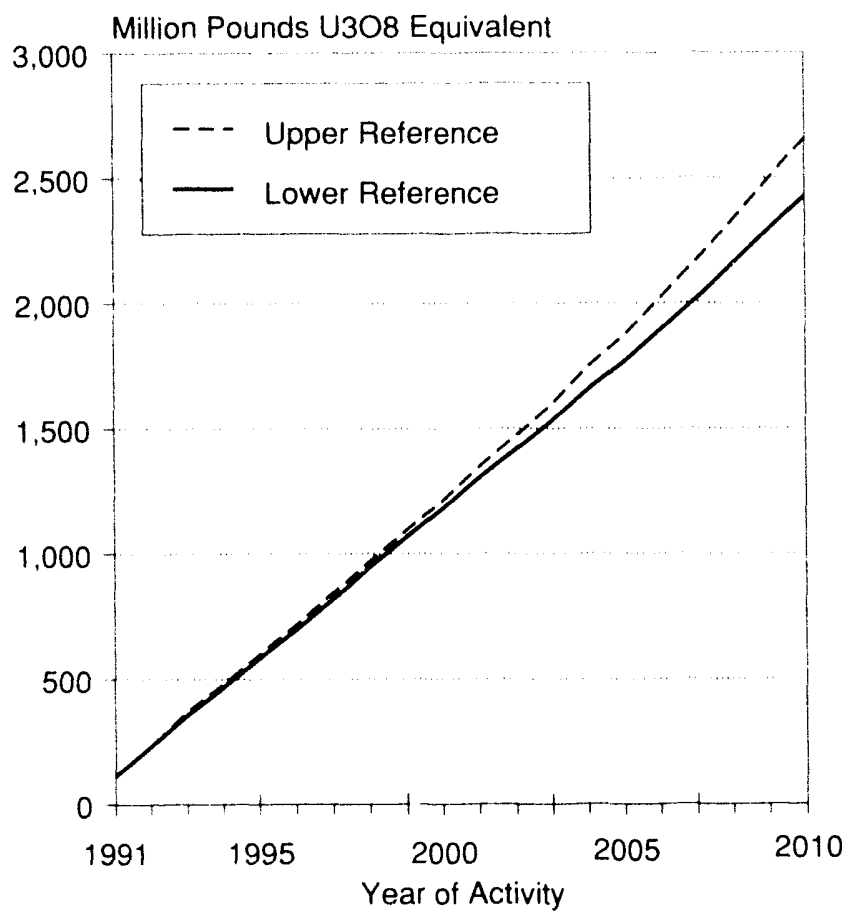

Source: Projected uranium requirements calculated using the International Nuclear Model, based on capacity projections from Energy Information Administration, Commercial Nuclear Power 1991: Prospects for the United States and the World, DOE/EIA-0438(91) (Washington, DC, August 1991).

\section{Mixed Oxide Fuel Plans}

With the exception of the Beznau units in Switzerland, usage of mixed oxide fuels in Europe will be confined to France and Germany for the near future. The French have plans to use mixed oxide fuels in 16 of their 900 MWe PWR reactors through the year 2000. The French nuclear industry is primarily controlled by Electricite de France (EdF) and has very little political opposition, which results in more uniform and efficient planning. To date, the Germans have had the most experience with use of MOX fuels. While a number of German reactors have plans for recycling plutonium, it is probable that some of these plans will be deferred or delayed because of either reprocessing and/or MOX fabrication availability or political constraints. Unlike the French reactors, German reactors are controlled by a number of individual utilities and are subject to both local and political pressures.

Unlike the French reactors which are under the central authority of EDF, the German reactors are operated by a number of independent utilities. Consequently there are no uniform fuel management schemes for use of MOX fuel, as there are in France. As a rule of thumb, one-third core MOX fuel is an upper limit, similar to the fuel plans in France. However, German reactors have loaded less than onethird cores because of license constraints and/or MOX availability. Fourteen German reactors were identified by EIA from available literature as possible users of MOX fuel over the projection period.

MOX fabrication capacity has been the constraining factor in Germany. In 1989, German courts limited the production of the Siemens-BrennelementewerkHanau MOX fabrication plant (formerly owned by ALKEM) to about 20 to 30 percent of capacity, pending the resolution of licensing irregularities. As a result, plans for some near-term usage of MOX fuel that were dependent on fabrication availability were put on hold as were plans for use of MOX fuel in reactors that have not yet received licenses. In addition, some of the more aggressive plans were tempered by scaling down the amount of MOX fuel or inter-mixing reloads containing MOX fuel with reloads containing all uranium fuel. The intermixing of MOX and all-uranium reloads has a historical precedent in Germany.

The political uncertainty towards reprocessing in Germany is reflected by clauses inserted in West German reprocessing contracts with British Nuclear Fuels and Cogema that would allow them to back out of the contracts, if laws were passed eliminating the German reprocessing option anytime through 2005.

The Japanese government has announced a policy that promotes the use of the recovered material first in LWR's and advanced thermal reactors (ATR) and eventually in fast breeder reactors (FBR). Use of MOX fuel is slated to be tested in one boiling water reactor and one pressurized-water reactor as well as in the Advanced Thermal reactor (ATR) Fugen. A full scale MOX program is scheduled to start in the late nineties. Based upon projections of plutonium availability and a maximum three-year storage of recovered plutonium, the Japanese estimate nine 1,000 MWe reactors will use MOX fuel by 2000 , with the number of reactors increasing to 12 by 2005 . 
Table 12. Projected Average Annual Uranium Enrichment Service Requirements for Nuclear Power Plants in the Free Market Economies, 1991-2010

(Million Separative Work Units)

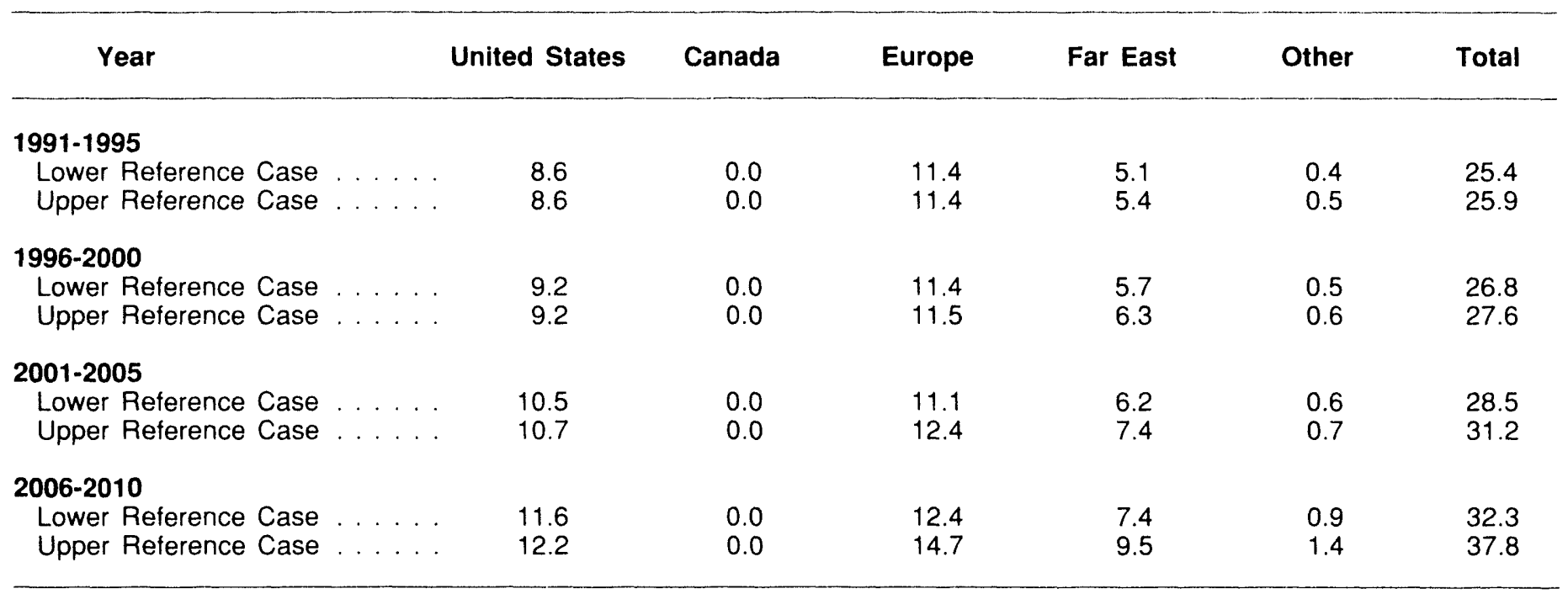

Source: Projected uranium requirements calculated using the International Nuclear Model, based on capacity projections from Energy Information Administration, Commercial Nuclear Power 1991: Prospects for the United States and the World, DOE/ElA-0438(91) (Washington, DC, August 1991).

Table 16 displays the fuel cycle statistics with and without MOX fuel diets for the Lower Reference case in Europe. Average annual requirements decrease by 2.4 percent in 1991 through 1995 and 4.7 in 2006 through 2010. Total uranium requirements decrease by 6.7 percent in 1995, dropping to a 6.3 percent decrease in 2010, the last year of the projection period. The affect of MOX fuel use on total uranium requirements is expected to decline over the projection period because some of the reactors using MOX fuel diets will be retired through the projection period, and their replacements are assumed to use only uranium oxide fuel. MOX fuel diets decrease annual enrichment services by 9.9 percent in 1991 through
1995 and by 4.7 percent in the years 2006 through 2010.

Table 17 displays the fuel cycle statistics with and without MOX fuel diets for the Lower Reference case for the Far East. As mentioned previously, Japan is the only country in the Far East planning to use MOX fuel. If MOX fuel is used on the scale as described above, total natural uranium requirements will decrease by 4.0 percent over the projection period, 1991-2010 and average annual enrichment service requirements will decrease by 4.8 percent in the years 2006 through 2010. 
Figure 10. Average Annual Uranium Enrichment Service Requirements for the Free Market Economics, 1991-2010

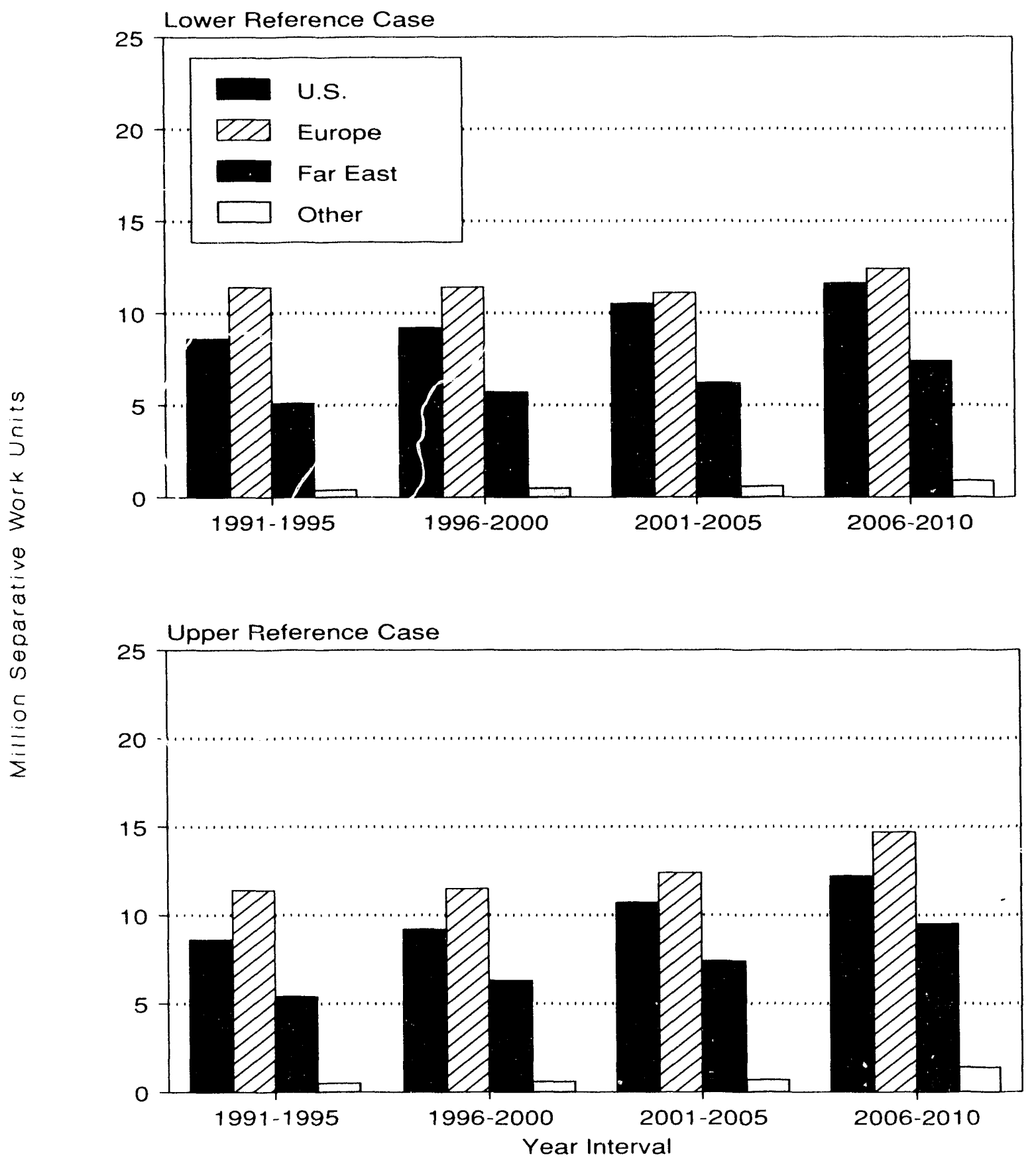

Source: Projected fuel-cycle requirements calculated using the International Nuclear Model, based on capacity projections from Energy Information Administration, Commercial Nuclear Power 1991: Prospects for the United States and the World, DOE/EIA-0438(91) (Washington, DC, August 1991). 
Table 13. Projected Nominal Capacity of World Uranium Enrichment Facilities at the End of the Year, 1990 and 1995

(Million Separative Work Units)

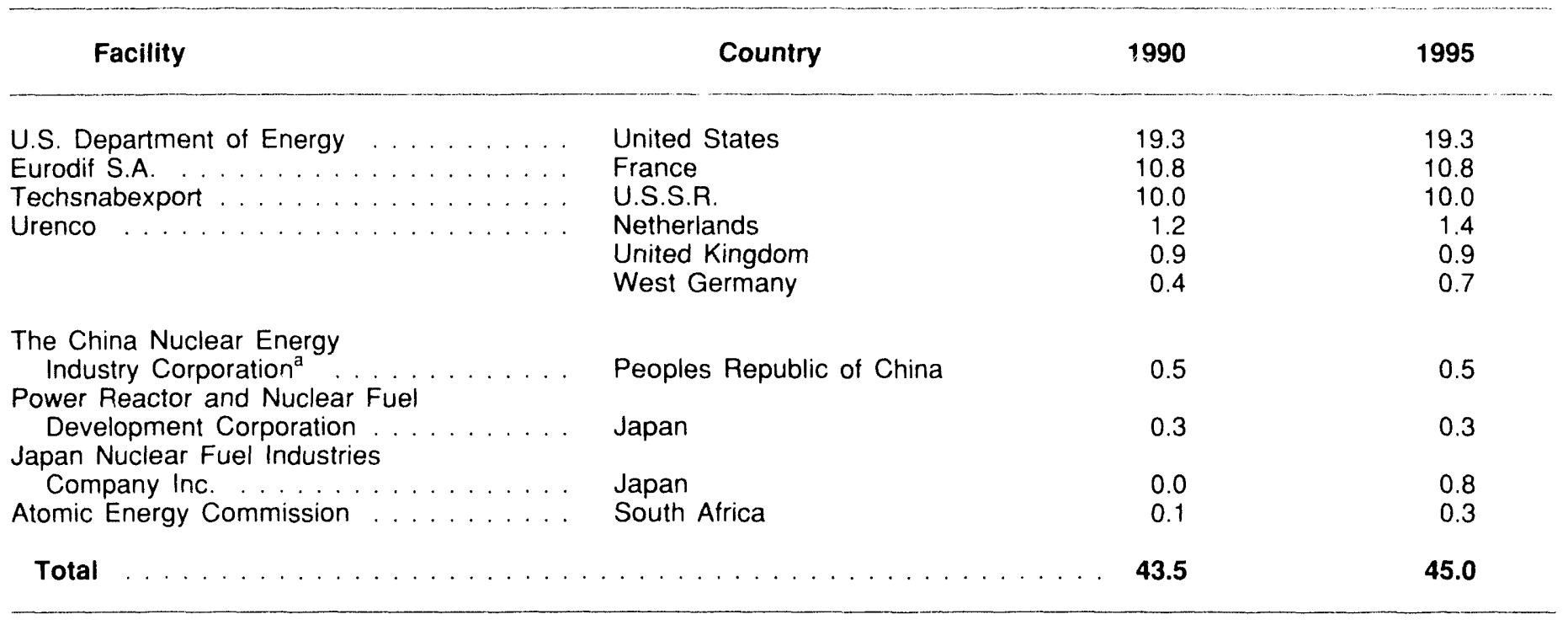

${ }^{\text {a}}$ Estimated availability to FME countries.

Source: Nuclear Assurance Corporation, Fuel Trac Enrichment Status Report (Atlanta, GA, February 1991).

Table 14. Projected Average Annual Discharges of Spent Fuel from Nuclear Power Plants in the Free Market Economies, 1991-2010

(Thousand Metric Tons of Initial Heavy Metal)

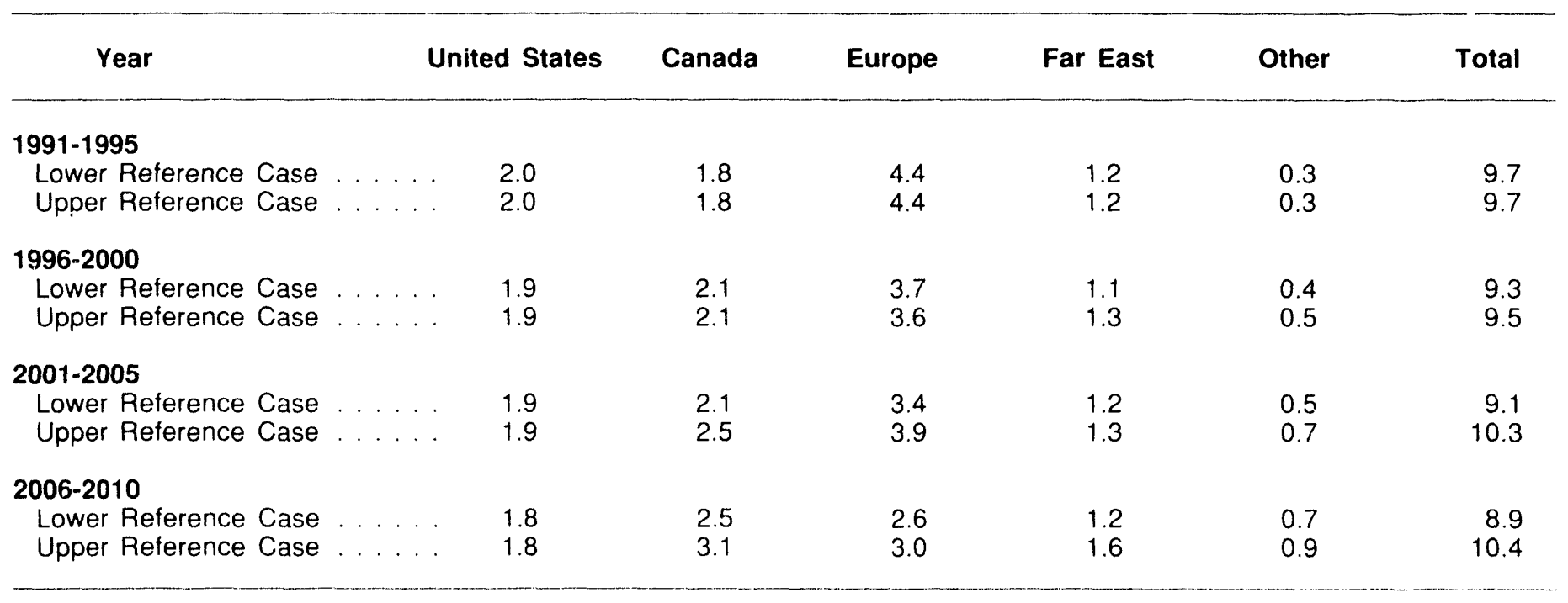

Note: Totals may not equal sum of components due to independent rounding.

Source: Projected uranium requirements calculated using the International Nuclear Model, based on capacity projections from Energy Information Administration, Commercial Nuclear Power 1991: Prospects for the United States and the World, DOE/EIA-0438(91) (Washington, DC, August 1991). 
Figure 11. Average Annual Nuclear Spent Fuel Discharges for the Free Market Economies, 1991-2010

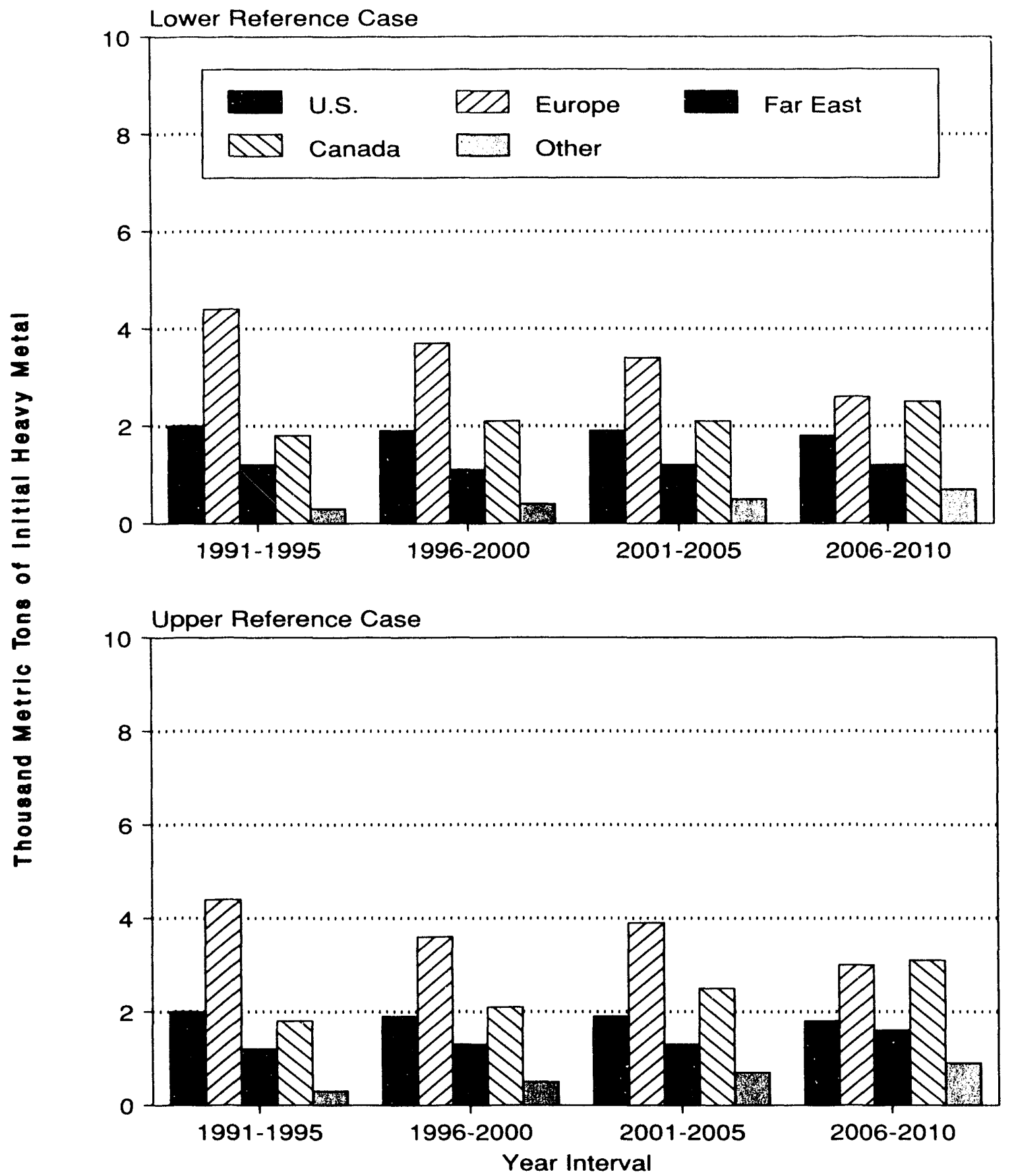

Source: Projected fuel-cycle requirements calculated using the International Nuclear Model, based on capacity projections from Energy Information Administration, Commercial Nuclear Power 1991: Prospects for the United States and the World, DOE/EIA-0438(91) (Washington, DC, August 1991). 
Table 15. Projected Cumulative Discharges of Spent Fuel from Nuclear Power Plants in the Free Market Economies, 1995-2010

(Thousand Metric Tons of Initial Heavy Metal)

\begin{tabular}{|c|c|c|c|c|c|c|}
\hline Year & United States & Canada & Europe & Far East & Other & Total \\
\hline \multicolumn{7}{|l|}{1995} \\
\hline $\begin{array}{l}\text { Lower Reference Case } \\
\text { Upper Reference Case }\end{array}$ & $\begin{array}{l}9.9 \\
9.9\end{array}$ & $\begin{array}{l}9.0 \\
9.2\end{array}$ & $\begin{array}{l}21.8 \\
21.8\end{array}$ & $\begin{array}{l}6.0 \\
6.0\end{array}$ & $\begin{array}{l}1.6 \\
1.7\end{array}$ & $\begin{array}{l}48.3 \\
48.6\end{array}$ \\
\hline \multicolumn{7}{|l|}{2000} \\
\hline $\begin{array}{l}\text { Lower Reference Case } \\
\text { Upper Reference Case }\end{array}$ & $\begin{array}{l}19.6 \\
19.6\end{array}$ & $\begin{array}{l}19.6 \\
19.5\end{array}$ & $\begin{array}{l}40.1 \\
39.5\end{array}$ & $\begin{array}{l}11.8 \\
12.4\end{array}$ & $\begin{array}{l}3.4 \\
4.4\end{array}$ & $\begin{array}{l}94.5 \\
95.4\end{array}$ \\
\hline \multicolumn{7}{|l|}{2005} \\
\hline $\begin{array}{l}\text { Lower Reference Case } \\
\text { Upper Reference Case }\end{array}$ & $\begin{array}{l}29.2 \\
29.2\end{array}$ & $\begin{array}{l}30.1 \\
31.9\end{array}$ & $\begin{array}{l}56.7 \\
58.5\end{array}$ & $\begin{array}{l}17.7 \\
18.8\end{array}$ & $\begin{array}{l}6.1 \\
7.8\end{array}$ & $\begin{array}{l}139.8 \\
146.2\end{array}$ \\
\hline \multicolumn{7}{|l|}{2010} \\
\hline $\begin{array}{l}\text { Lower Reference Case } \\
\text { Upper Reference Case }\end{array}$ & $\begin{array}{l}38.4 \\
38.4\end{array}$ & $\begin{array}{l}42.5 \\
47.4\end{array}$ & $\begin{array}{l}69.5 \\
72.9\end{array}$ & $\begin{array}{l}23.9 \\
26.5\end{array}$ & $\begin{array}{r}9.5 \\
12.5\end{array}$ & $\begin{array}{l}183.8 \\
197.7\end{array}$ \\
\hline
\end{tabular}

Note: Discharges of spent fuel are cumulative from 1991.

Source: Projected uranium requirements calculated using the International Nuclear Model, based on capacity projections from Energy Information Administration, Commercial Nuclear Power 1991: Prospects for the United States and the World, DOE/EIA-0438(91) (Washington, DC, August 1991).

Table 16. Sensitivity of Lower-Reference-Case Projections for European Nuclear Fuel Cycle Requirements to Mixed-Oxide Fuel Use Assumptions, 1991-2010

$\begin{array}{llll}\text { Projection Without Mox Fuel With MOX Fuel } & \text { Percent Difference }\end{array}$

Average Annual Natural Uranium Requirements (million pounds $\mathrm{U}_{3} \mathrm{O}_{8}$ equivalent)

\begin{tabular}{|c|c|c|c|}
\hline $\begin{array}{l}1991-1995 \\
1996-2000 \\
2001-2005 \\
2006-2010\end{array}$ & $\begin{array}{l}45.1 \\
46.6 \\
44.1 \\
49.2\end{array}$ & $\begin{array}{l}44.0 \\
43.0 \\
41.4 \\
46.9\end{array}$ & $\begin{array}{l}-2.4 \\
-7.8 \\
-6.2 \\
-4.7\end{array}$ \\
\hline
\end{tabular}

Total Natural Uranium Requirements (million pounds $\mathrm{U}_{3} \mathrm{O}_{s}$ equivalent)

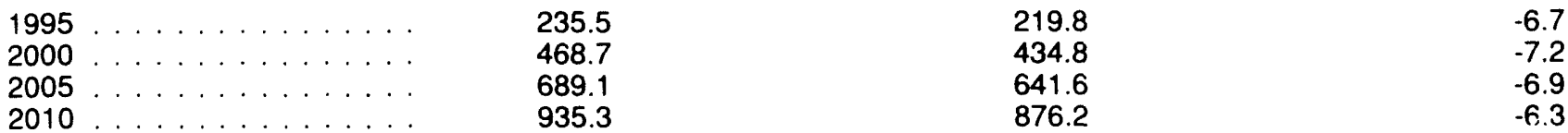

Average Annual Uranium Enrichment Service Requirements (million separative work units)

\begin{tabular}{|c|c|c|}
\hline $\begin{array}{l}1991-1995 \\
1996-2000 \\
2001-2005 \\
2006-2010\end{array}$ & $\begin{array}{l}10.2 \\
10.6 \\
10.2 \\
11.8\end{array}$ & $\begin{array}{l}-9.9 \\
-7.1 \\
-8.1 \\
-4.7\end{array}$ \\
\hline
\end{tabular}

Source: Projected fuel cycle requirements calculated using the International Nuclear Model, based on capacity projections from Energy Information Administration, Commercial Nuclear Power 1991: Prospects for the United States and the World, DOE/EIA-0438(91) (Washington, DC, September 1991). 


\section{Trible 17. Sensitivity of Lower Reference-Case Projections for the Far East to Mixed-Oxide Fuel Use Assumptions, 1991-2010}

Projection Without MOX Fuel

With MOX Fuel

Percent Difference

Average Annual Natural Uranium Requirements (million pounds $U_{3} O_{4}$ equivalent)

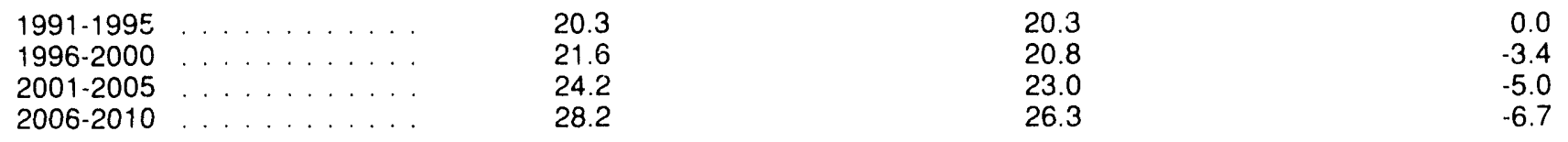

Total Natural Uranium Requirements (million pounds $\mathrm{U}_{3} \mathrm{O}_{8}$ equivalent)

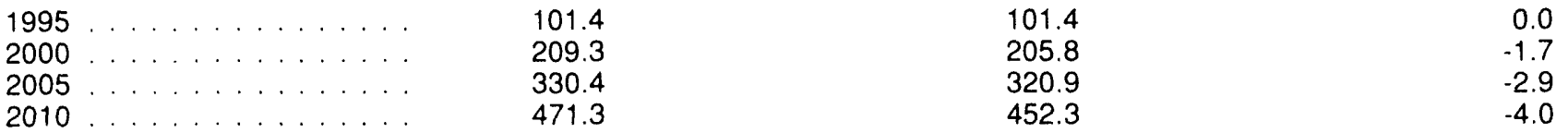

Average Annual Uranium Enrichment Service Requirements (million separative work units)

\begin{tabular}{|c|c|c|c|}
\hline $\begin{array}{l}1991-1995 \\
1996-2000 \\
2001-2005 \\
2006-2010\end{array}$ & $\begin{array}{l}5.1 \\
5.7 \\
6.2 \\
7.4\end{array}$ & $\begin{array}{l}5.1 \\
5.6 \\
5.9 \\
7.1\end{array}$ & $\begin{array}{l}0.0 \\
-2.2 \\
-4.9 \\
-4.8\end{array}$ \\
\hline
\end{tabular}

Source: Projected fuel cycle requirements calculated using the International Nuclear Model, based on capacity projections from Energy Information Administration, Commercial Nuclear Power 1990: Prospects for the United States and the World, DOE/EIA-0438(91) (Washington, DC, August 1991). 


\section{Comparison With Other Forecasts}

This chapter compares the projections of the fuel cycle requirements made by the Energy Information Administration in 1991 with those of other forecasts, namely: (1) the projections made by EIA in 1990 which were reported in last year's edition of this report, ${ }^{5}$ (2) Fuel-Tras reports from the Nuclear Assurance Corporation (NAC), (3) a market analysis by Energy Resources International, ${ }^{7}$ and (4) Data Systems reports from NUKEM. The comparisons are based on total requirements for 1991 through 1995, and for 1996 through 2000. Projected fuel cycle requirements are compared for the United States (Table 18) and for the FME countries excluding the United States (Table 19). This comparison provides the reader with analysis of different forecasts which can be used to help make judgments as to the accuracy of ElA's projections.

\section{Comparison With Last Year's EIA Report}

The cumulative U.S. uranium requirements from 1991 through 2000 projected in this report $(420$ million pounds $\mathrm{U}_{3} \mathrm{O}_{8}$ ) are 6.6 percent higher than those projected in last year's report, and the cumulative enrichment service requirements through 2000 (89 million separative work units) are 4.7 percent higher than projected last year (Table 18). The higher estimates of uranium and enrichment requirements are explained by slightly higher installed capacity and capacity factor assumptions than were assumed for last year. The projections of U.S. spent fuel discharges (19.5 thousand metric tons) are 4.6 percent more than reported in 1990, for the same reasons. Installed capacity increased because of changes in the assumptions concerning when units in the construction pipeline start operation.

Table 20 shows the percentage errors in predicting annual and cumulative U.S. spent fuel discharges for a 4-year period. The EIA uses the International
Nuclear Model (INM) to make nuclear fuel cycle projections. Last year's forecast of spent fuel discharges for 1990 was equal to the actual spent fuel discharge of 2.2 thousand metric tons. In earlier reports, the absolute values of the error in EIA's predictions of annual spent fuel discharge ranged from 0 percent to 43 percent.

\section{Comparison With Other Reports}

The basic process for modeling nuclear fuel cycle requirements is essentially the same for all forecasters. The major differences among the various forecasts are due to differing perceptions of current conditions and different combinations of exogenous assumptions regarding capacity factors, tails assays, fresh fuel assays, and burnup. The comparison of input data and assumptions is much more important than the comparison of projected numerical fuel cycle requirements among the different reports. Unfortunately, complete listings of the controlling assumptions generally are not presented with the projected numerical values.

EIA's projections of fuel cycle requirements are reactor requirements only and, as such, are independent of considerations of inventories of natural uranium and separative work. Moreover, they do not take into account existing contracts for future requirements. EIA presents its market analyses in its uranium industry viability assessment."

For U.S. fuel cycle requirements, the EIA projections this year are higher than those projected last year. For cumulative U.S. uranium requirements from 1991 through $2000\left(420\right.$ million pounds $\left.\mathrm{U}_{3} \mathrm{O}_{4}\right)$, the differences compared to other forecasts range between 7 percent lower to 8 percent higher, and for enrichment requirements the other forecasts are between 2 percent lower and 19 percent higher than the EIA projections ( 89 million separative work units) (Figure 12).

\footnotetext{
¿Energy Information Administration, World Nuclear Fuel Cycle' Requirements 1990), DOE/EIA-(0436(90) (Washington, DC, October 1990). "Nuclear Assurance Corporation, Fuel-Trac Reports: " $\mathrm{U}_{1} \mathrm{O}_{\mathrm{k}}$ Status Report"; "Enrichment Status Report"; and "Discharge Fuel/Reprocessing Report" (Atlanta, CA, February 1991).

Eitergy Resources International, Inc., 1991 Nuclear Fud Cycle Supply and Price Report (Washington, DC, April 1991).

${ }^{8}$ NUKEM, Inc., NUKEM Data Systems (Stanford, CT, December 1990)).

"Energy Information Administration, Domestic Uranium Mining and Milling Industry: 1989 Viability Assessment, DOE/EIA-(0477(89) (Washington, DC, December 1990).
} 
Table 18. Comparison of Selected Forecasts of U.S. Fuel Cycle Requirements

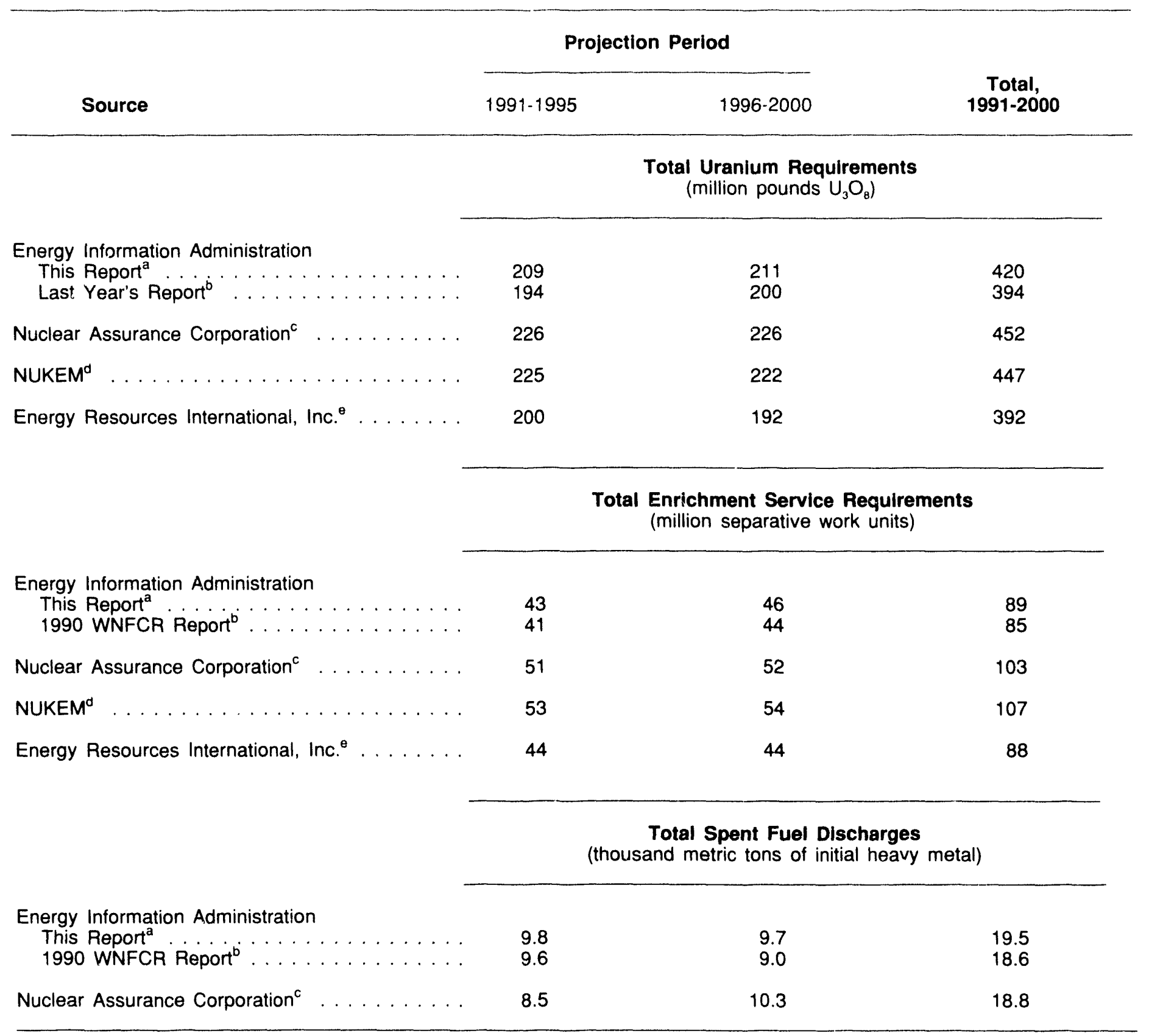

Note: Differences in this year's projections made by the Energy Information Administration from last year's report are due to changes in assumptions about installed capacity and fuel cycle operating parameters.

Sources:

${ }^{a}$ Energy Information Administration, 1991 Upper-Reference-case projections.

'Energy Information Administration, World Nuclear Fuel Cycle Requirements 1990, DOE/EIA-0436(90) (Washington, DC, October 1990). Upper-Reference-case projections.

"Nuclear Assurance Corporation, Fuel-Trac Reports: " $\mathrm{U}_{3} \mathrm{O}_{8}$ Status Report"; "Enrichment Status Report"; and "Discharge Fuel/Reprocessing Report" (Atlanta, GA, February 1991).

"NUKEM, Inc., NUKEM Data Systems (Stamford, CT, December 1990).

${ }^{\theta}$ Energy Resources International, Inc., 1991 Nuclear Fuel Cycle Supply and Price Report (mid range) (Washington, DC, April 1991). 
Table 19. Comparison of Selected Forecasts of Fuel Cycle Requirements for the Free Market Economies, Excluding the United States

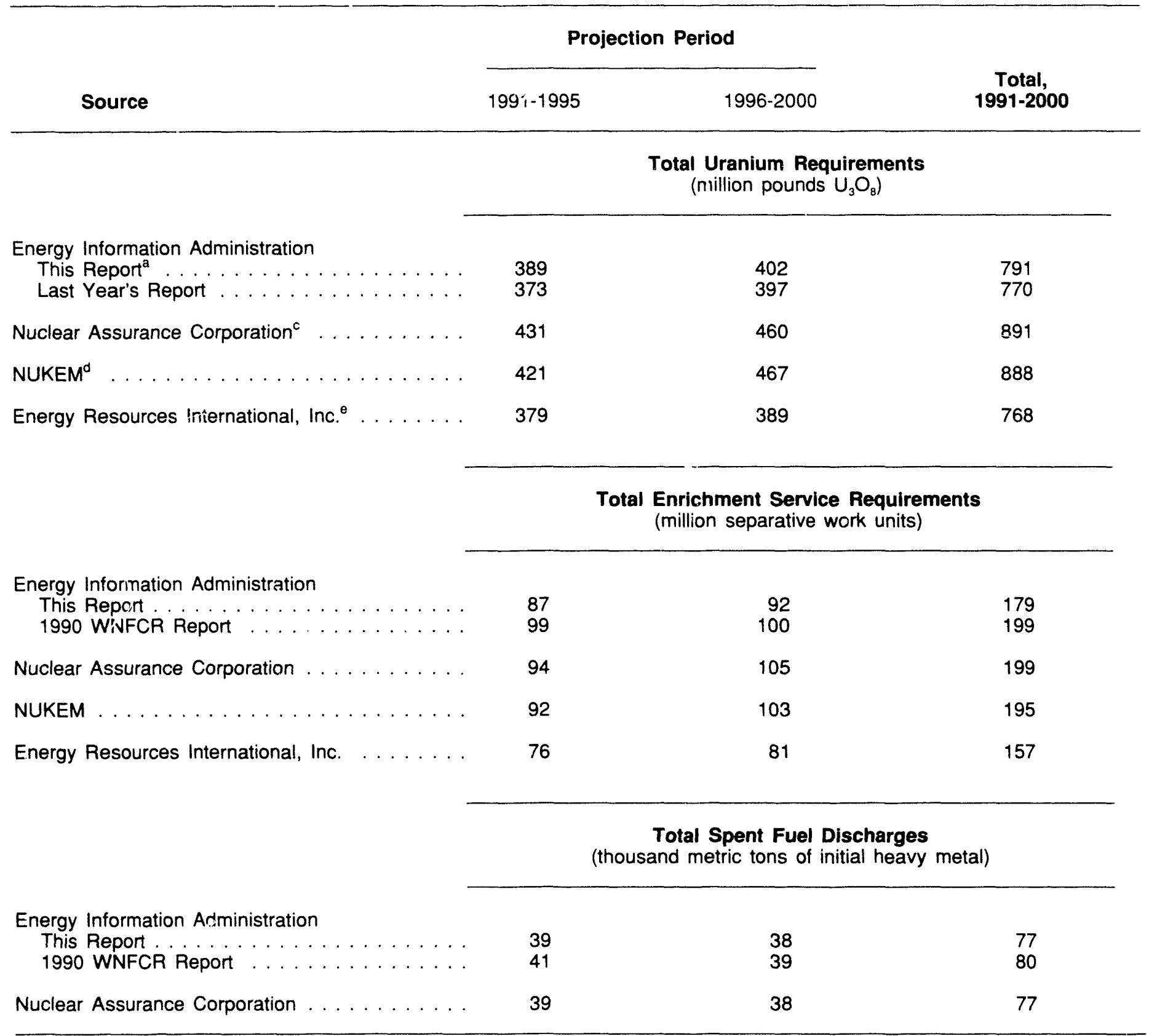

Note: Differences in this year's projections made by the Energy Information Administration from last year's report are due to changes in assumptions about installed capacity, and fuel cycle operating parameters.

anergy Information Administration, 1991 Upper-Reference-case projections.

bEnergy Information Administration, World Nuclear Fuel Cycle Requirements 1990, DOE/EIA-0436(90) (Washington, DC, October 1990). Upper-Reference-case projections.

"Nuclear Assurance Corporation, Fuel-Trac Reports: " $\mathrm{U}_{3} \mathrm{O}_{8}$ Status Report"; "Enrichment Status Report"; and "Discharge Fuel/Reprocessing Report" (Atlanta, GA, February 1991).

'NUKEM, Inc., NUKEM Data Sysioms (Stamford, CT, December 1990).

EEnergy Resources International, I c., 1991 Nuclear Fuel Cycle Supply and Price Report (mid range) (Washington, DC, April 1991). 
Table 20. Percentage Error in Predicting Spent Fuel Discharges

\begin{tabular}{llcccc}
\hline & \multicolumn{5}{c}{ Year Forecast Made } \\
\cline { 2 - 5 } Years Ahead & 1985 & 1986 & 1987 & 1988 & 1989 \\
\hline
\end{tabular}

\begin{tabular}{|c|c|c|c|c|c|c|c|}
\hline \multirow{3}{*}{$\begin{array}{l}0 \\
1 \\
2 \\
3\end{array}$} & & \multicolumn{5}{|c|}{ Annual Spent Fuel } & \multirow[b]{2}{*}{$\begin{array}{r}0.0 \\
-- \\
-- \\
-.\end{array}$} \\
\hline & $\ldots$ & $\begin{array}{l}0.0 \\
\text { N/A } \\
\text { N/A } \\
\text { N/A }\end{array}$ & $\begin{array}{r}-7.1 \\
-26.7 \\
0.0 \\
-5.3\end{array}$ & $\begin{array}{r}-18.7 \\
-13.3 \\
0.0 \\
-29.4\end{array}$ & $\begin{array}{r}15.0 \\
-42.9 \\
-10.0 \\
--\end{array}$ & $\begin{array}{r}4.8 \\
-22.2 \\
-- \\
-\cdot\end{array}$ & \\
\hline & & \multicolumn{6}{|c|}{ Cumulative Spent Fuel } \\
\hline $\begin{array}{l}0 \\
1 \\
2 \\
3\end{array}$ & $\ldots \ldots$ & $\begin{array}{l}-0.8 \\
\text { N/A } \\
\text { N/A } \\
\text { N/A }\end{array}$ & $\begin{array}{l}-2.2 \\
-4.6 \\
-3.5 \\
-3.7\end{array}$ & $\begin{array}{l}-2.6 \\
-2.3 \\
-2.1 \\
-3.8\end{array}$ & $\begin{array}{r}1.7 \\
-1.6 \\
-1.9 \\
--\end{array}$ & $\begin{array}{r}0.5 \\
-0.9 \\
-- \\
-.\end{array}$ & $\begin{array}{r}0.5 \\
-- \\
-- \\
--\end{array}$ \\
\hline
\end{tabular}

$\mathrm{N} / \mathrm{A}=$ Not available.

$--=$ Not applicable.

Sources: Actual spent fuel discharges 1985-1989: Energy Information Administration Spent Nuclear Fuel Discharges from U.S. Reactors 1989 (Service Report), SR/CNEAF/91-01 (Washington, DC, February 1991); 1990: Form RW-859 "Nuclear Fuel Data" (1990). Projected Spent Fuel Discharges 1985-1990: Energy Information Administration, World Nuclear Fuel Cycle Requirements, DOE/EIA-0436 (Washington DC).

For FME fuel cycle requirements excluding the United States, the EIA projections are also low by comparison with the other forecasts, but are not the lowest (Table 19 and Figure 13). For cumulative FME uranium requirements through the year 2000, the differences range between 3 percent lower to 13 percent higher than the EIA projections (791 million pounds $\mathrm{U}_{3} \mathrm{O}_{k}$ ). For EIA projections of cumulative FME enrichment requirements (179 million separative work units), the differences range between 12 percent higher and 12 percent lower. Other projections of FME requirements are lower than EIA's because of the lower transactions tails assay $(0.25$ percent versus 0.30 percent $U-235)$ assumed by the EIA.

In this respect, differences in projections of nuclear generating capacities and capacity factors, as well as differences in assumptions of fuel management variables, such as cycle length, refueling (batch) fraction, fuel enrichment levels, and burnup, have an impact on the amount of fuel required to generate a given amount of electricity, and will affect the projected fuel requirements. The enrichment tails assays under which the nuclear fuel is produced also affect the balance betw'een uranium and enrichment requirements.

As with the basic EIA scenarios, the projections of installed nuclear capacity are generally similar among the forecasts through the late 1990's. However, differences in projected capacity factors affect the projections of electricity generation, which in turn affect projected fuel cycle requirements. The EIA generally projects lower capacity factors; thus, the EIA projections are generally lower than the other forecasts. In addition, the EIA perceives generally higher and increasing levels of fuel burnup, as opposed to the other forecasts, which typically assume lower burnup levels. The differences in the burnup projections, together with the changes implied for the other fuel management variables that are physically and economically dependent on fuel burnup, further account for the differences between forecasts. 
Figure 12. Comparison of Fuel Cycle Requirements from ElA and Other Reports for the United States, 1991-2000

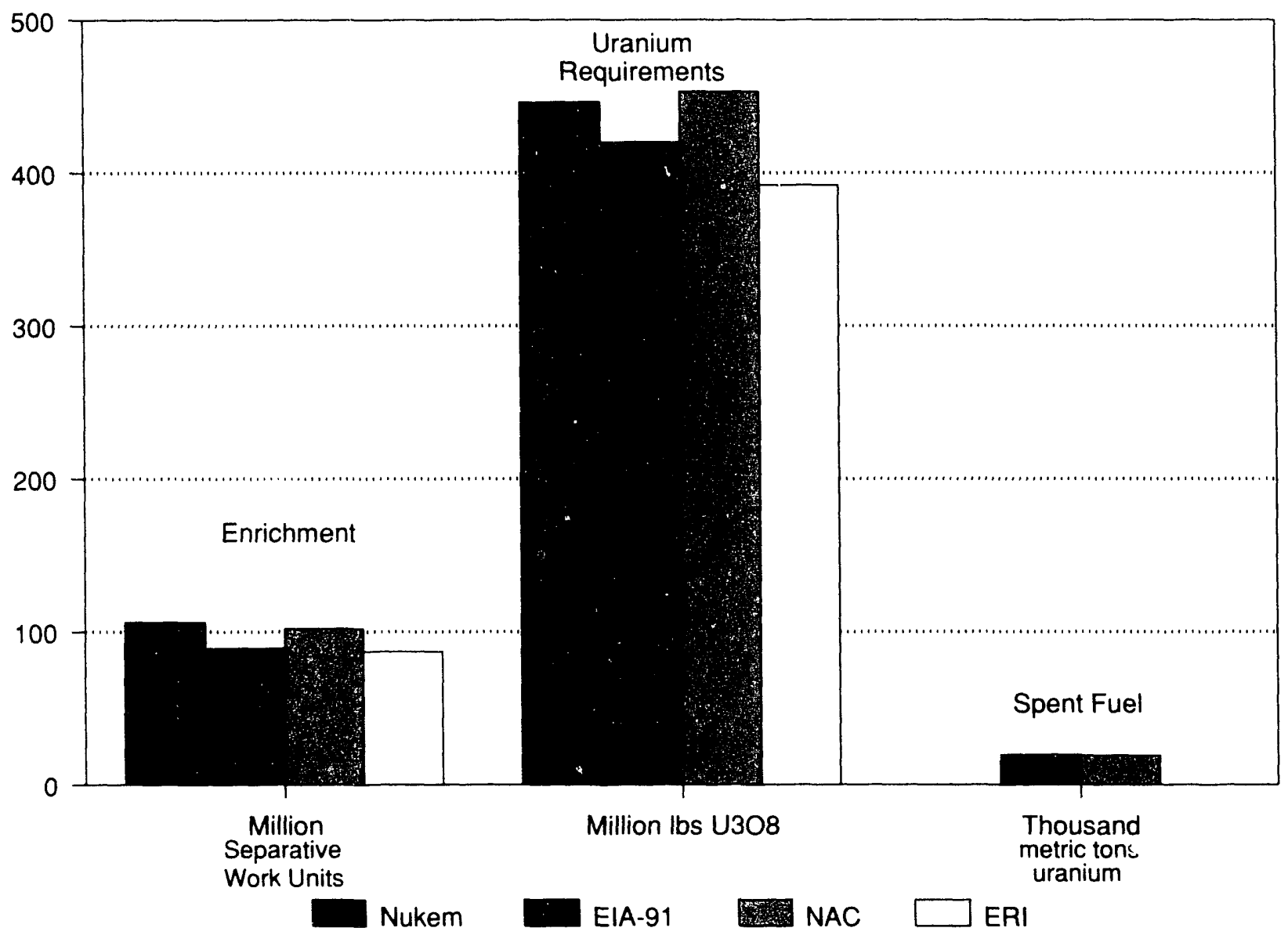

Sources: Energy Information Administration, 1991 Upper-Reference-case projections. Nuclear Assurance Corporation, Fuel-trac Reports: "U $\mathrm{U}_{3} \mathrm{O}_{8}$ Status Report"; "Enrichment Status Report"; and "Discharge Fuel/Reprocessing Report" (Atlanta, GA, February 1991). NUKEM, Inc., NUKEM Data Systems (Stamford, CT, December 1990). Energy Resources International, Inc., 1991 Nuclear Fuel Cycle Supply and Price Report (Washington, DC, April 1991). 
Figure 13. Comparison of Fuel Cycle Requirements from EIA and Other Reports for Free Market Economies Excluding the United States, 1991-2000

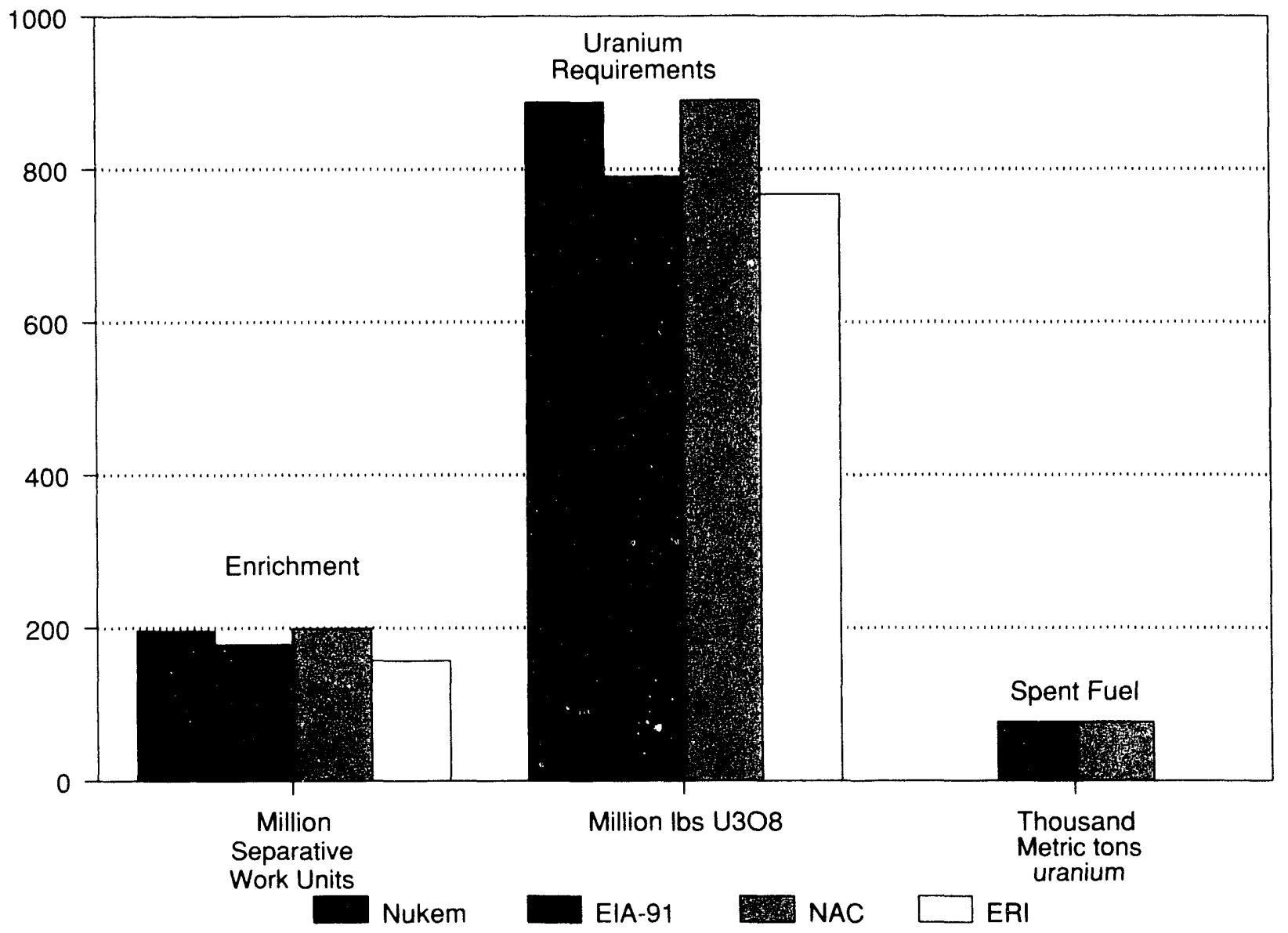

Sources: Energy Information Administration, 1991 Upper-Reference-case projections. Nuclear Assurance Corporation, Fueltrac Reports: " $\mathrm{U}_{3} \mathrm{O}_{3}$ Status Report"; "Enrichment Status Report"; and "Discharge Fuel/Reprocessing Report" (Atlanta, GA, February 1991). NUKEM, Inc., NUKEM Data Systems (Stamford, CT, December 1990). Energy Resources International, Inc., 1991 Nuclear Fuel Cycle Supply and Price Report (Washington, DC, April 1991). 


\section{Nuclear Assurance Corporation (NAC) Fuel-Trac Status Reports}

Most of the differences between the EIA projections and the NAC projections are caused by NAC's assumption of significantly higher operating capacity factors and lower initial and constant burnup levels, which, as explained above, combine to produce higher projected consumption of both natural uranium and enrichment services and higher discharges of spent fuel. The following comparisons apply to the 1991 through 2000 timeframe: For the United States, the NAC projections of uranium and enrichment (452 million pounds $\mathrm{U}_{3} \mathrm{O}_{6}$ and 103 million separative work units), are 7.9 and 15.2 percent higher respectively, than the EIA projections. Their spent fuel projections (18.8 thousand metric tons) are 3.5 percent lower. For the FME nations, NAC's projections of uranium and enrichment requirements $\left(891\right.$ million pounds $\mathrm{U}_{3} \mathrm{O}_{4}$ and 199 million separative work units) are 12.6 and 11.7 percent higher than ElA's, but the projection of spent fuel is the same.

\section{Energy Resources International (ERI) Report}

The Mid Range Projection of the Energy Resources International (ERI) report is very close to the EIA projections with regard to U.S. nuclear generating capacity. The ERI forecast was based on a higher transaction tails assay projection than that used by EIA. The burnup assumptions for different reactor types were not directly specified, but significant improvements in uranium and enrichment utilization efficiency were projected. For the 1991 through 2000 timeframe, EIA's projected U.S. reactor requirements (420 million pounds $\mathrm{U}_{3} \mathrm{O}_{8}$ ) are 6.6 percent higher for uranium and 2.0 percent higher for enrichment services (89 million separative work units) than the ERI projections.
ERI's projections for the FME nations (768 million pounds $\mathrm{U}_{3} \mathrm{O}_{8}$ and 157 million separative work units) were 2.9 percent lower for uranium and 11.9 percent lower for enrichment than ElA's projections for 1991 through 2000. The higher overall fuel cycle requirements (uranium plus enrichment) are attributable to slightly higher projections of installed nuclear capacity and somewhat higher capacity factor assumptions than projected by the ERI. The higher relative difference between the projected enrichment requirements is explained by a significant difference in the transaction tails assays assumed for foreign FME reactor requirements.

\section{NUKEM Data Systems Reports}

For the United States, the NUKEM projections (447 million pounds $\mathrm{U}_{3} \mathrm{O}_{8}$ and 107 million separative work units) are 6.2 percent higher than EIA's projections for uranium requirements and 19.4 percent higher for enrichment service requirements. For the FME nations, the NUKEM projections (888 million pounds $\mathrm{U}_{3} \mathrm{O}_{8}$ and 195 million separative work units) are 12.2 percent higher for natural uranium requirements and 9.7 percent higher for enrichment service requirements than the EIA projections for the 1991 through 2000 period. It can be shown, however, with the impacts projected in the sensitivity cases, that the significant differences in the underlying assumptions account for the differences between the two sets of forecasts. The capacity factors projected by NUKEM are significantly higher than those assumed by EIA, and this is the major cause of the differences in projected fuel requirements. Also, EIA assumes that nuclear fuel burnup levels will increase significantly in the future, whereas NUKEM projects constant fuel management plans for PWR's and BWR's operating beyond their third refueling cycles. The resulting differences in fuel utilization efficiencies contribute to the differences between the two projections. 


\section{Appendix A}

Nuclear Power

Technology and the Nuclear Fuel Cycle 


\section{Appendix A}

\section{Nuclear Power Technology and the Nuclear Fuel Cycle}

\section{Nuclear Fission}

When the feasibility of the nuclear fission reaction was confirmed in 1939, scientists recognized that tremendous amounts of energy could be released by this process. Although early attempts to harness this energy were directed to military purposes, the harnessing of nuclear fission to produce electricity eventually became a commercial technology.

The nuclear fission process is one in which a heavy atomic nucleus (such as uranium) reacts with a free neutron. ${ }^{10}$ Most of the time this "reaction" is one in which the uranium nucleus splits (or "fissions") into two smaller nuclei, concurrently releasing energy and two or three additional free neutrons. Because more neutrons are released from a fission event than are needed to induce the event, a "chain reaction" can be sustained.

Of course, to be useful for commercial purposes, the rate of the chain reaction must be controlled. This is not as difficult as it might seem because nearly every other nucleus besides uranium reacts with free neutrons, usually by absorbing the neutron rather than by fissioning. Thus, a fission chain reaction is controlled by diluting the fissionable uranium atoms with other nonfissionable atoms.

Uranium in nature consists primarily of two "isotopes" -atoms with the same number of protons in the nucleus but different numbers of neutrons. One isotope is designated uranium-235 (or U-235); the other is uranium-238 (U-238). The numbers refer to the atomic mass, which is the sum of the number of protons and neutrons in the nucleus.

U-235 makes up only 0.7 percent of naturally occurring uranium; U-238 makes up almost all of the other 99.3 percent. U-235 nearly always reacts with a free neutron (that is, one outside the nucleus) by fissioning; thus, U-235 is called a "fissile" isotope. On the other hand, U-238 nearly always reacts with a free neutron by absorbing it rather than by fissioning. This absorption forms the isotope U-239, which in turn undergoes radioactive decay and eventually becomes Pu-239, an isotope of the element plutonium. $\mathrm{Pu}-239$, like U-235, is a fissile isotope. U-238 is referred to as a "fertile" isotope, because it eventually produces the fissile $\mathrm{Pu}-239$ isotope.

The vast majority of the world's nuclear power plants operate by passing ordinary (that is, "light") water through a nuclear reactor in which uranium fuel, housed in an array of "fuel assemblies," undergoes a controlled chain reaction. The heat produced by nuclear fission events in the reactor core is carried away by the water, either as steam in a "boilingwater reactor" or as superheated water in a "pressurized-water reactor." In a pressurized-water reactor, a device called a "steam generator" transfers the heat from water in the primary loop (which has passed through the reactor core) to water in a secondary loop, which is turned into steam. Steam produced in either a boiling-water reactor or a pressurized-water reactor then passes to an electrical turbine-generator, which actually produces the electricity. Boiling-water reactors and pressurizedwater reactors are collectively called "light-water reactors." Other reactor designs have also been developed, such as the gas-cooled reactor, advanced gas-cooled reactor, and pressurized heavy-water reactor; these are used for commercial power generation in a number of foreign countries.

Because the coolant (water) in light-water reactors absorbs free neutrons, the concentration of fissile U-235 in uranium fuel must be increased over the concentration of 0.7 percent found in natural uranium in order for light-water reactors to sustain a nuclear chain reaction. The process of uranium enrichment, as discussed below, is used to increase the concentration of U-235 in the nuclear fuel used in light-water reactors to about 3 percent.

\footnotetext{
${ }^{10}$ Atomic nuclei consist of combinations of two types of subatomic particles, protons and neutrons, of about equal mass. The number of electrically charged protons in a nucleus determines which element it is-that is, its chemical properties. The number of protons plus the number of electrically neutral neutrons determines the weight or "atomic mass" of the nucleus. A "free neutron" is one that has been released from an atomic nucleus.
} 
Before the initial startup of a nuclear power reactor, the core is loaded with fresh nuclear fuel. This fuel can be thought of as a reservoir from which energy is extracted as long as a chain reaction can be sustained. During the operation of the reactor, the concentration of U-235 decreases as U-235 nuclei fission to produce energy. In addition, fertile U-238nuclei are constantly being converted into fissile Pu-239 nuclei, some of which will, in turn, fission and produce energy. While these reactions are going on, the concentration of neutron-absorbing fission products (also called "poisons") increases within the nuclear fuel assemblies. When the declining concentration of fissile nuclei and the increasing concentration of poisons reach the point at which a chain reaction can no longer be sustained (that is, when free neutrons are absorbed at a rate greater than the rate of fission events), the reactor must be shut down and refueled.

The amount of energy in the "reservoir" of nuclear fuel is frequently expressed in terms of "full-power days," which is the number of days the reactor could operate at full output before a fission chain reaction would cease to be sustained. If a reactor is not operated at full power, or if it is not operated at all times, the chronological operating period is increased correspondingly. The operating period varies inversely with the plant's "capacity factor," which is the ratio of its actual level of operation to the maximum, fullpower level of operation for which it is designed.

As might be expected, the number of full-power days in a nuclear reactor's operating cycle (from one refueling to the next) is related to the amount of fissile U-235 contained in the fuel assemblies at the beginning of the cycle. The higher the percentage of U-235 at the initiation of a cycle, the greater the number of full-power days of operation in that cycle.

At the end of an operating cycle (when the chain reaction can no longer be sustained), some of the "spent" nuclear fuel is discharged and replaced with fresh fuel. The fraction of the reactor's fuel replaced at a refueling is called its "batch fraction" - typically, one-fourth for boiling-water reactors and one-third for pressurized-water reactors.

The amount of energy extracted from spent fuel is called its "burnup," expressed in terms of energy (heat) produced per initial fuel weight-such as, megawattdays thermal per metric ton of initial heavy metal.

\section{The Nuclear Fuel Cycle}

The nuclear fuel cycle for a typical light-water reactor is illustrated in Figure A1. The cycle consists of a "front end" that comprises the steps necessary to prepare nuclear fuel for reactor operation and a "back end" that comprises the steps necessary to manage the spent nuclear fuel, which is highly radioactive. It is technically possible to extract the unused uranium and plutonium from spent nuclear fuel through chemical reprocessing and to recycle the recovered uranium and plutonium as nuclear fuel. The front end of the cycle is divided into the following steps:

- Exploration. Ore bodies containing uranium are first located by drilling and other geological techniques. Known deposits of ore for which enough information is available to estimate the quantity and cost of production are called reserves. Ore deposits inferred to exist but as yet undiscovered are called potential resources.

- Mining. Uranium-bearing ore is mined by methods similar to those used for other metal ores. The uranium content of ores in the United States typically ranges from 0.05 to 0.3 percent uranium oxide $\left(\mathrm{U}_{3} \mathrm{O}_{8}\right)$. In foreign countries the uranium content of ores varies widely, from 0.035 percent in South West Africa to 2.5 percent in northern Saskatchewan, Canada. In general, foreign ores are of a higher grade than those mined in the United States. Commercially significant amounts of uranium are also obtained by methods other than conventional mining, such as solution mining, and as a byproduct of phosphate mining.

- Milling. At uranium mills, usually located near the mines, uranium-bearing ore is crushed and ground, and the uranium oxide is chemically extracted. The mill product, called uranium concentrate or "yellowcake," is then marketed and sold as pounds or short tons of $\mathrm{U}_{3} \mathrm{O}_{k}$.

- Conversion to $\mathrm{UF}_{6}$. Next, the $\mathrm{U}_{3} \mathrm{O}_{\mathrm{s}}$ is chemically converted to uranium hexafluoride $\left(U F_{h}\right)$, which is a solid at room temperature but changes to a gas at slightly higher temperatures. This is a necessary feature for the next step, enrichment.

- Enrichment. Natural uranium cannot be used as fuel in light-water reactors because its content of fissile U-235 is too low to sustain a nuclear chain reaction. The gaseous diffusion process currently used for uranium enrichment (that is, increasing its U-235 content) consists of passing a "feed stream" of UF gas through a long series of diffusion barriers that pass U-235 at a faster rate than the heavier U-238 atoms. This differential ireatment progressively increases the percentage of $U-235$ in the "product stream." The "waste stream" or "enrichment tails stream" contains the depleted uranium (that is, uranium having a U-235 
Figure A1. The Nuclear Fuel Cycle

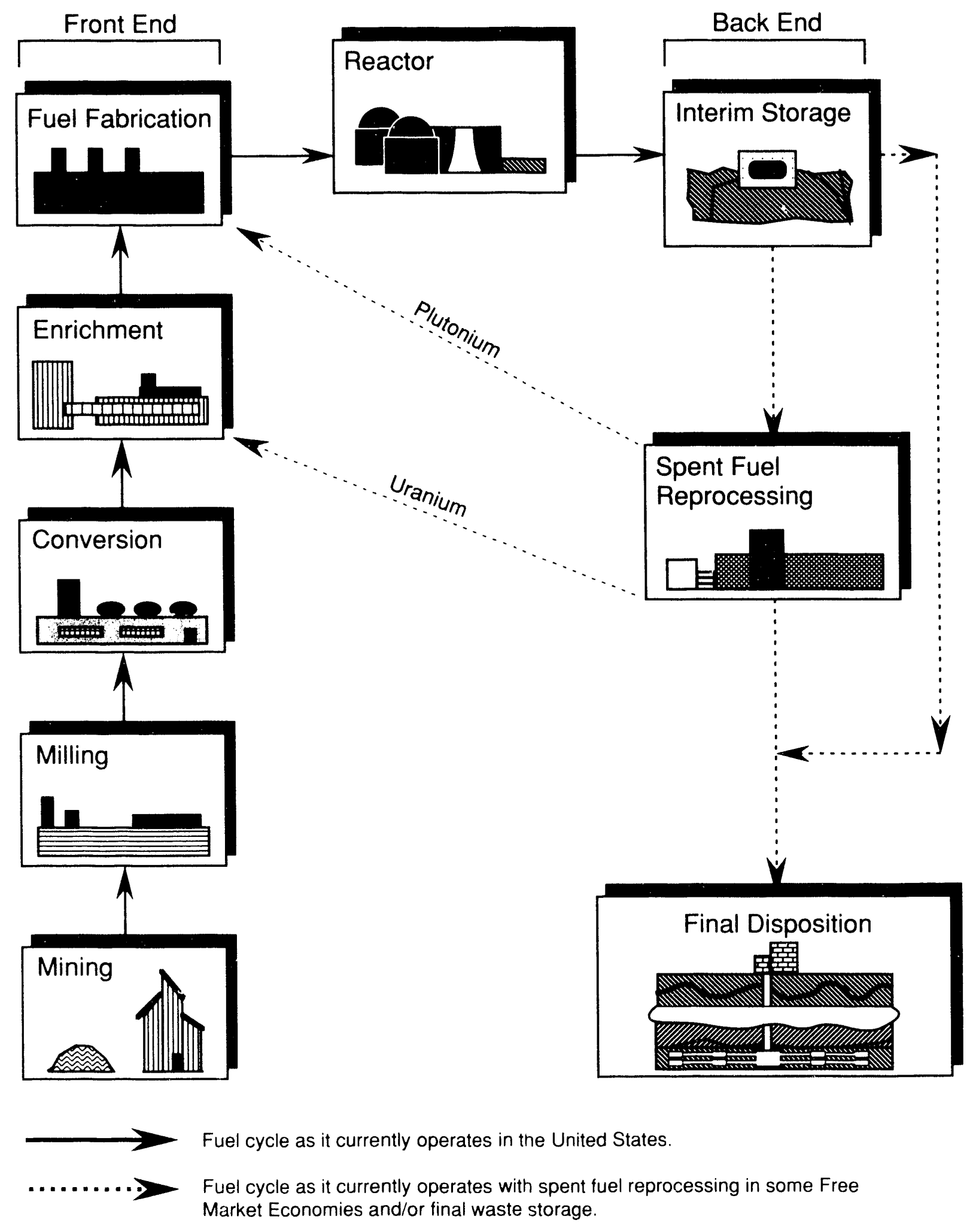


concentration below the natural concentration of 0.7 percent). The U-235 concentration in the waste stream, called the "enrichment tails assay," is fixed by the operator of the enrichment facility. The gaseous diffusion enrichment process is extremely energy intensive. The work or energy expenditure required for uraniuni enrichment is measured in terms of separative work units.

A second enrichment technology, gas centrifuge separation, has been used commercially in the Netherlands. A domestic gas centrifuge separation plant was under construction but has now been canceled. A third enrichment technology, laser separation, is currently under development.

- Fabrication. The enriched $\mathrm{UF}_{6}$ is changed to an oxide and then into pellets of ceramic uranium dioxide $\left(\mathrm{UO}_{2}\right)$, which are then sealed into corrosion-resistant tubes of zirconium alloy or stainless steel. The loaded tubes, called elements or rods, are mounted into special assemblies for loading into the reactor.

The back end of the cycle is divided into the following steps:

- Interim Storage. After its operating cycle, the reactor is shut down for refueling. The fuel discharged at that time (spent fuel) is stored either at the reactor site or, potentially, in a common facility away from reactor sites. If on site pool storage capacity is exceeded, it may be desirable to store aged fuel in modular dry storage facilities at the reactor site or at a facility away from the site. The spent fuel rods are usually stored in water, which provides both cooling (the spent fuel continues to generate heat as a result of residual radioactive decay) and shielding (to protect the environment from residual ionizing radiation).

- Reprocessing. Spent fuel discharged from lightwater reactors contains appreciable quantities of fissile (U-235, Pu-239), fertile (U-238), and other radioactive materials. These fissile and fertile materials can be chemically separated and recovered from the spent fuel. The recovered uranium and plutonium can, if economic and institutional conditions permit, be recycled for use as nuclear fuel.

- Waste Disposal. A current concern in the nuclear power field is the safe disposal and isolation of either spent fuel from reactors or, if the reprocessing option is used, wastes from reprocessing plants. These materials must be isolated from the biosphere until the radioactivity contained in them has diminished to a safe level. Under the Nuclear Waste Policy Act of 1982, as amended, the Department of Energy has responsibility for the development of the waste disposal system for spent nuclear fuel and high-level radioactive waste. Current plans call for the ultimate disposal of the wastes in solid form in licensed deep, stable geologic structures. 


\title{
Appendix B
}

\author{
Methodology and \\ Assumed Fuel Cycle \\ Plans for Increased \\ Fuel Burnup
}




\section{Appendix B}

\section{Methodology and Assumed Fuel Cycle Plans for Increased Fuel Burnup}

\section{The Model}

The estimates of the nuclear fuel cycle requirements in this report were produced with the International Nuclear Model (INM). This model was developed under contract for the Nuclear and Alternate Fuels Division of the Office of Coal, Nuclear, Electric and Alternate Fuels in the Energy Information Administration (EIA)." The INM is used to simulate nuclear fuel cycle operations.

The data for the INM include the following general ategories:

- Operating Reactor Data. This is a list of information on nuclear reactors assumed to be operable during the time period being analyzed. For each reactor, the list includes the name, start and retirement dates, net summer capability, generic category to which the reactor is assigned, indicators of the fuel management plans to be used, and the applicable dates for the fuel management plans.

- Generic Reactor Data. Each operating reactor is classified into one of the generic categories, such as boiling-water reactor and pressurizedwater reactor. The data for the generic categories of reactors include capacity factors, thermal efficiency, maintenance priority, and a list of allowable fuel management plans.

- Fuel Management Data. The data describing a fuel management plan are used to simulate the internal workings of operating reactors. Fuel management data consist of the following: full power days, capacity factors, kilograms of enriched uranium per megawatt of capacity loaded during each refueling, spent fuel discharged, assays of the fissile isotopes in the fuel loaded and discharged, and fraction of core replaced.
- Fuel Cycle Parameters. These data items include lead and lag times from the start of a cycle for the fuel cycle processes (that is, conversion, enrichment, fabrication, spent fuel disposal), tails assays for enrichment services, ${ }^{12}$ process mass-loss factors, and process waste production.

- Control/Scenario Data. The user can specify data such as annual capacity factors for all equilibrium cycles.

Annual requirements for uranium concentrate $\left(\mathrm{U}_{3} \mathrm{O}_{4}\right)$ and enrichment services, as well as discharges of spent fuel, are a function of the fuel management plan being used by each reactor, and the specified tails assay for enrichment services. To calculate the annual requirements, the date for the start of a cycle is determined for each reactor by a formula that uses (a) the number of full power days specified in the fuel management plan and (b) the capacity factor. (A "full-power day" is the equivalent of 24 hours of fullpower operation of a reactor.) The length of the cycle can then be determined as follows:

\section{Length of cycle $=$ \\ (number of full-power days) / (capacity factor).}

The length of the cycle includes the time during which electricity is being generated and the time during which the reactor is not operating (such as during refueling). The lead times for fuel cycle services must also be incorporated: $\mathrm{U}_{3} \mathrm{O}_{8}$ is delivered to a conversion plant 15 months before the restart of the nuclear unit, and enrichment services begin 12 months before the restart of the unit. Finally, the quantities of $\mathrm{U}_{3} \mathrm{O}_{8}$ and enrichment services required are determined from the amount of enriched uranium specified in the fuel management plan and from the enriched product assay and transaction tails assay. For a new reactor, the fuel management data and the lead times for the initial cycles are unique. After a reactor

\footnotetext{
"David Andress, System Sciences Inc., International Nuclear Model, Vols. I, II, and III (Bethesda, MD, 1985).

":Tails assay" refers to the concentration of the U-235 isotope in the waste stream from the enrichment process. The higher the concentration of U-235 in the waste, the lower the requirement for enrichment service but the greater the requirement for natural uranium for a given quantity of enriched uranium produced.
} 
has reached equilibrium, the full-power days in a cycle, the quantity of fuel loaded, and the spent fuel discharged per cycle remain constant for a specific fuel management plan.

The INM is used to produce annual summary reports for generic reactor categories and totais for all reactors. These reports include: annual generation of electricity, annual capacity factors, annual and cumulative requirements for $\mathrm{U}_{3} \mathrm{O}_{4}$ and enrichment services, annual discharges of spent fuel, and total spent fuel discharges less the spent fuel withdrawn for reprocessing. The uranium concentrate requirements are reported as requirements for $\mathrm{U}_{3} \mathrm{O}_{4}$ or "yellowcake"; the enrichment service requirements are measured in separative work units; and the discharges of spent fuel are expressed in metric tons of initial heavy metal. The projected discharges of spent fuel exclude discharged fuel that is designated for reinsertion.

\section{Nuclear Fuel Management Plans and Nuclear Fuel Burnup}

Fuel management plans for the generic reactor categories were developed from a statistical analysis of historical fuel cycle data. The historical data include the following: capacity, fuel inserted per cycle $\left(\mathrm{U}_{3} \mathrm{O}_{4}\right.$, uranium metal, $\left.\mathrm{U}-235\right)$, requirements for uranium enrichment service, cycle length, capacity factor, full-power days, spent fuel discharges, and fuel burnup.

Nuclear fuel burnup is a measure of the amount of energy produced from each metric ton of enriched uranium. The average burnup levels have been increasing and increases are expected to continue. For boiling-water reactors, the average equilibrium spent fuel discharge burnup in 1990 was approximately 28,000 MWDT/MTIHM. The burnup values ranged from less than 20,000 to more than 38,000 MWDT/ MTIHM. The majority of spent fuel discharges (74 percent) were between 26,000 and 32,000 MWDT/ MTIHM. For pressurized-water reactors, the average equilibrium spent fuel discharge burnup in 1990 was about 36,000 MWDT/MTIHM. The values ranged from under 20,000 to $52,000 \mathrm{MWDT} / \mathrm{MTIHM}$, with the majority of spent fuel discharges (67 percent) between 34,000 and 41,000 MWDT/MTIHM. Appendix D shows projected equilibrium discharge burnup levels from 1991 through 2030.

Equilibrium design burnup levels for U.S. commercial nuclear fuel in the early 1980's were around 28,000 and 33,000 MWDT/MTIHM for boiling-water reactors and pressurized-water reactors, respectively. Engineering advances in fuel integrity and improved fuel management techniques were developed through a joint effort by Government and industry, resulting in higher design burnups. In this report, fuel with design burnup above $28,0(0)$ MWDT/MTIHM for boiling-water reactors and $33,000 \mathrm{MWDT} / \mathrm{MTHHM}$ for pressurized-water reactors is referred to as "extended burnup fuel." The following pages of this Appendix describe the procedures used to develop fuel plans associated with extended fuel burnup levels.

A fuel plan consists of:

- Amount of uranium loaded

- Enrichment assay of the uranium loaded

- Planned number of full-power days

- Design burnup level of the discharged spent fuel.

In an ideal equilibrium cycle, any two of the above parameters determine the other two parameters. The equations relating the parameters are:

$$
F B=S D,
$$

and

$$
E=a+b B(1+F),
$$

where:

$F=$ fraction of the core being replaced in an equilibrium reloading,

$B=$ equilibrium discharge batch average burnup (megawattdays thermal per metric ton of initial heavy metal),

$D=$ equilibrium full-power days (days),

$S=$ core specific power (megawatts thermal per metric ton of initial heavy metal),

$E=$ enrichment assay (percent),

and $a$ and $b$ are regression coefficients.

The fraction of the core replaced is functionally equivalent to the amount of enriched uranium loaded.

Equation (1) implies that in an equilibrium mode, the core average burnup, $S D$, equals the discharge batch average burnup, $B$, times the batch fractional average, $F$. For example, if $F=1 / 3$ and $B=33,000$ megawattdays thermal per metric ton of initial heavy metal, then the core average burnup is 11,000 megawattdays thermal per metric ton of initial heavy metal. That is, a batch of fuel stays in the core for three cycles, receiving an exposure of 11,000 megawattdays thermal per metric ton of initial heavy metal during each cycle. The core specific power, $S$, depends on the particular reactor and core configuration being considered. However, there is a 
high correlation between core specific power and the ratio of the reactor's rated thermal power to core size (uranium content), so that for modeling purposes, $S$ can be considered invariant for an individual reactor.

Equation (2) assumes a linear reactivity model, that is, that the rate of change of reactivity with fuel burnup is constant. The parameters $a$ and $b$ are fixed values determined from the analysis of a coupled thermalhydraulic nuclear fuel cycle; $b$ depends on bundle design, and $a$ depends on leakage. Both $a$ and $b$ can be affected by design variables governing the conversion ratio and change in the slope of reactivity versus burnup. In an ideal equilibrium cycle, Equation (2) may be interpreted as relating enrichment assay to total burnup, where total burnup is defined as the sum of the discharge burnup, $B$, and the cycle equilibrium burnup, $B F$. In practice, the assumption of a linear relationship between enrichment assay and total burnup must be tempered because of the incorporation of burnable poisons with the nuclear fuel. Burnable poisons are used in higher burnup fuel to control reactivity and limit power peaking. The addition of burnable poisons to the nuclear fuel requires moderate increases in enrichment assays to obtain a given burnup objective. This additional U-235 requirement introduces an upward concavity in the enrichment-burnup relationship. However, Equation (2) does provide a good estimate of the relationship over a reasonable burnup range.

Under the conditions described above, Equations (1) and (2) provide a reasonable approximation for an ideal equilibrium cycle. To obtain generic parameters characterizing a typical boiling-water reactor and pressurized-water reactor, estimates of the coefficients in Equation (2) are obtained using a regression analysis.

The regression parameters in Equations (3) and (4) below were estimated by a regression analysis applied to fuel management projections supplied to DOE by utilities on Form RW-859. Separate estimates were made for boiling-water reactors and pressurized-water reactors. Only fuel with zircalloy cladding was considered. Prior to applying the regression analysis, anomalous data were identified and eliminated from the analysis set. The R-squared values were 0.81 for both pressurized-water reactors and boiling-water reactors (Table $\mathrm{B} 1$ ).

The " $t$ " test was used to test the regression coefficients against the null hypothesis that they were not significantly different from zero. This test produces a statistical measure for determining whether a variable should be included in the model. In all cases, the coefficients were statistically significant at the 0.0001 level (Table B2).

Substituting the results of the regression analysis in Equation (2) yields the following expressions. For boiling-water reactors:

$$
E=0.746+0.0000531 B(1+F) .
$$

For pressurized-water reactors:

$$
E=0.766+0.0000525 B(1+F) .
$$

The projected discharge burnup data from Form RW-859, "Nuclear Fuel Data Survey," that was used in this analysis peaked at 39,000 megawattdays thermal per metric ton of initial heavy metal for boiling-water reactors and 48,000 megawattdays thermal per metric ton of initial heavy metal for pressurized-water reactors. Equations (3) and (4) are not applied to burnup levels exceeding these limits, because utilities are only now developing fuel management plans for burnup levels past these limits, and utility-supplied data for fuel management plans associated with these higher burnup goals are not currently available. For higher burnup ranges, the following analysis is used to establish the relationship between burnup, enrichment assay, and core replacement fraction.

Estimates of the technical parameters in Equation (2) were supplied by General Electric Corporation. Equation (2) can be written in the following difference format:

\begin{tabular}{|c|c|c|c|c|}
\hline Reactor Type & $\begin{array}{l}\text { Independent } \\
\text { Variable }\end{array}$ & Intercept & $\begin{array}{c}\text { Burnup x } \\
(1+\text { Core Fraction })\end{array}$ & R-squared \\
\hline $\begin{array}{l}\text { Boiling-Water Reactor . . } \\
\text { Pressurized-Water Reactor }\end{array}$ & $\begin{array}{l}\text { Assay } \\
\text { Assay }\end{array}$ & $\begin{array}{l}0.746 \\
0.766\end{array}$ & $\begin{array}{l}0.0000531 \\
0.0000525\end{array}$ & $\begin{array}{l}0.81 \\
0.81\end{array}$ \\
\hline
\end{tabular}

Table B1. Results of the Regression Analysis of the Enrichment Assay Equations 


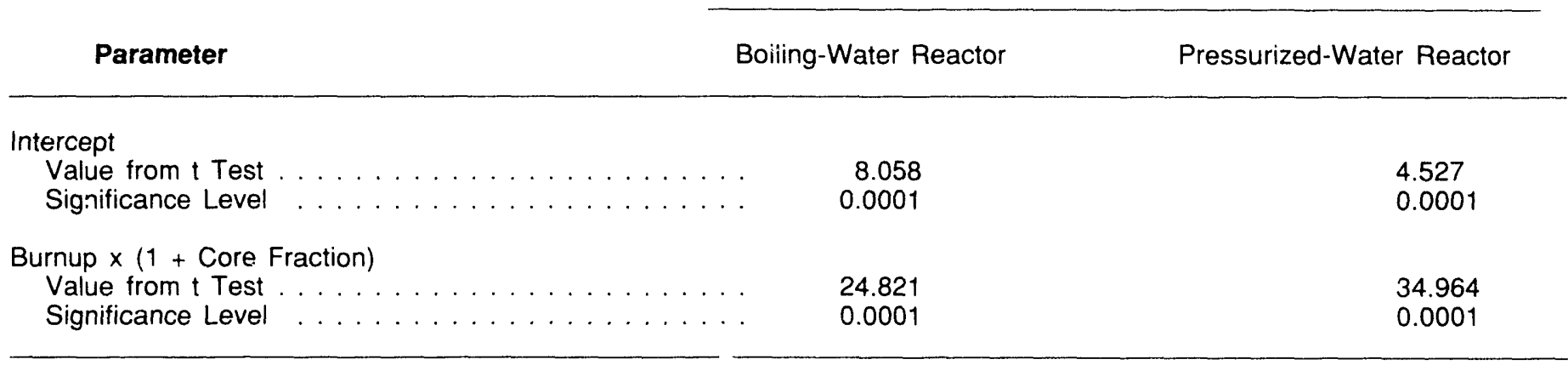

$$
E=b \Delta[B(1+F)],
$$

where $\Delta$ indicates the difference operator. This equation is appiied to a given fuel management plan consisting of an assay $E_{1}$, a burnup $B$, and a core fraction $F_{1}$. If a new fuel management plan has a burnup $B_{2}$ and a core fraction $F_{2}$, then

$$
\Delta[B(1+F)]=B_{2}\left(1+F_{2}\right)-B_{1}\left(1+F_{1}\right) .
$$

The change in enrichment assay is calculated vy $\Delta E=b \Delta[B(1+F)]$, and the new enrichment assay is given by $E_{2}=E_{1}+E$.

General Electric Corporation suggested that an appropriate value of $b$ in the higher bui nup ranges is 0.000063 . This value of $b$ provides a good approximation for both boiling-water reactors ind pressurized-water reactors. Note that the value oi the parameter $a$ in Equation (2) depends on the gerseric reactor type. Using the General Electric Corporation value for $b$, Equation (6) becomes

$$
\Delta E=0.000063 \Delta[B(1+F)] .
$$

As Equation (1) indicates, for a given discharge burnup and a given number of effective full-power days per cycle, the core fraction depends on the specific power of the reactor. The reactor fuel management plans used in the INM are based on the generic reactor types and implicitly incorporate a mean specific power value for a generic boiling-water and pressurized-water reactors, respectively.

Equation (1) is used to calculate the core fraction of a new fuel diet plan,

$$
F=(S D) / B,
$$

Utilities typically develop fuel management plans to meet effective full-power days and discharge burnun goals. That is, they specify the amount of energy to be produced during the cycle and the desired discharge burnup of the fuel, and use these objectives to determine the amount and enrichment assay of the fresh uranium loaded. The burnup objectives are generally determined by ecor.umic and operational considerations.

Domestic and foreign fuel management plans for extended burnup are developed for generic boilingwater reactors and pressurized-water reactors (Tables B3 and B4). Each plan is based on assumptions for the number of effective full-power days for the cycle and a discharge burnup level. Trends in burnup and number of effective full-power day plans were obtained from utility-supplied data and industry experts.

The following five steps were used to develop fuel models consistent with increases in fuel burnup and the number of effective full-power days per cycle. The procedure was applied separately to generic boilingwater reactors and pressurized-water reactors and for domestic and foreign reactors.

1. The mean core-sperific power (ratio of ma - iw watts thermal to core weight in metric tons of uranium) was converted separately for the boiling-water and pressurized-water reactors in the forecast data base.

2. The core fraction associated with a given burnup rvel and number of effective fullpowe ${ }^{\prime}$ days was computed by Equation (8). 
Table B3. Domestic Fuel Management Plans for Extended Burnup Scenarios

\begin{tabular}{|c|c|c|c|c|}
\hline Year Fuel Plan is Used & $\begin{array}{l}\text { Effective } \\
\text { Full-Power } \\
\text { Days }\end{array}$ & $\begin{array}{c}\text { Core } \\
\text { Fraction }\end{array}$ & $\begin{array}{c}\text { Enrichment } \\
\text { Assay } \\
\text { (Percent) }\end{array}$ & $\begin{array}{c}\text { Design } \\
\text { Burnup } \\
\text { (MWDT/MTIHM) }\end{array}$ \\
\hline 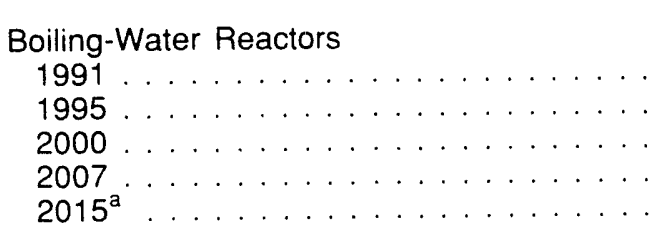 & $\begin{array}{l}411 \\
450 \\
489 \\
511 \\
530\end{array}$ & $\begin{array}{l}0.287 \\
0.288 \\
0.289 \\
0.274 \\
0.266\end{array}$ & $\begin{array}{l}3.02 \\
3.22 \\
3.38 \\
3.61 \\
3.78\end{array}$ & $\begin{array}{l}33,000 \\
36,000 \\
39,000 \\
43,000 \\
46,000\end{array}$ \\
\hline 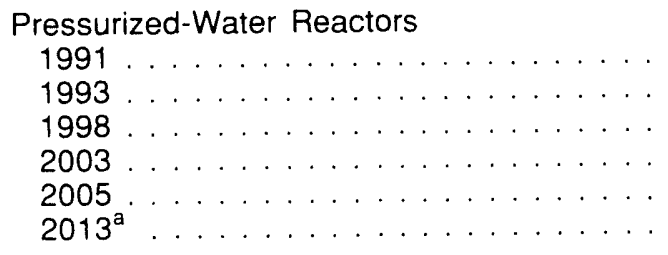 & $\begin{array}{l}411 \\
431 \\
460 \\
485 \\
511 \\
511\end{array}$ & $\begin{array}{l}0.380 \\
0.380 \\
0.370 \\
0.359 \\
0.344 \\
0.315\end{array}$ & $\begin{array}{l}3.66 \\
3.81 \\
4.07 \\
4.38 \\
4.76 \\
5.07\end{array}$ & $\begin{array}{l}40,000 \\
42,000 \\
46,000 \\
50,000 \\
55,000 \\
60,000\end{array}$ \\
\hline
\end{tabular}

aHigh-burnup sensitivity case.

Table B4. Foreign Fuel Management Plans for Extended Burnup Scenarios

\begin{tabular}{|c|c|c|c|c|}
\hline Year Fuel Plan is Used & $\begin{array}{l}\text { Effective } \\
\text { Full-Power } \\
\text { Days }\end{array}$ & $\begin{array}{c}\text { Core } \\
\text { Fraction }\end{array}$ & $\begin{array}{c}\text { Enrichment } \\
\text { Assay } \\
\text { (Percent) }\end{array}$ & $\begin{array}{c}\text { Design } \\
\text { Burnup } \\
\text { (MWDT/MTIHM) }\end{array}$ \\
\hline \multicolumn{5}{|l|}{ Europe } \\
\hline 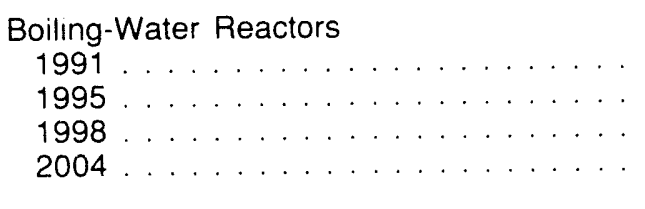 & $\begin{array}{l}300 \\
300 \\
300 \\
300\end{array}$ & $\begin{array}{l}0.225 \\
0.206 \\
0.191 \\
0.173\end{array}$ & $\begin{array}{l}2.91 \\
3.07 \\
3.18 \\
3.38\end{array}$ & $\begin{array}{l}33,000 \\
36,000 \\
39,000 \\
43,000\end{array}$ \\
\hline 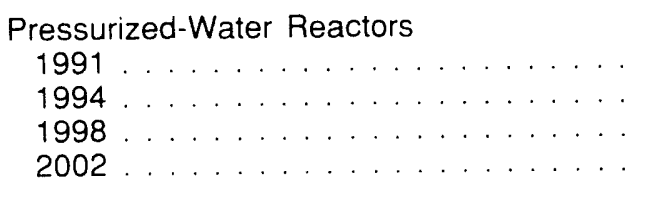 & $\begin{array}{l}281 \\
281 \\
281 \\
281\end{array}$ & $\begin{array}{l}0.278 \\
0.258 \\
0.235 \\
0.217\end{array}$ & $\begin{array}{l}3.38 \\
3.54 \\
3.75 \\
4.00\end{array}$ & $\begin{array}{l}39,000 \\
42,000 \\
46,000 \\
50,000\end{array}$ \\
\hline Far East & & & & \\
\hline $\begin{array}{l}\text { Boiling-Water Reactors } \\
1991 \ldots \ldots \ldots \ldots \\
1995 \ldots \ldots \ldots \ldots \\
1999 \ldots \ldots \ldots \ldots\end{array}$ & $\begin{array}{l}355 \\
365 \\
395 \\
420\end{array}$ & $\begin{array}{l}0.256 \\
0.241 \\
0.241 \\
0.232\end{array}$ & $\begin{array}{l}3.16 \\
3.33 \\
3.48 \\
3.72\end{array}$ & $\begin{array}{l}33,000 \\
36,000 \\
39,000 \\
43,000\end{array}$ \\
\hline $\begin{array}{l}\text { Pressurized-Water Reactors } \\
1991 \ldots \ldots \ldots \ldots \\
1995 \ldots \ldots \ldots \\
1999 \ldots \ldots \ldots \ldots\end{array}$ & $\begin{array}{l}355 \\
365 \\
395 \\
420\end{array}$ & $\begin{array}{l}0.367 \\
0.338 \\
0.332 \\
0.310\end{array}$ & $\begin{array}{l}3.48 \\
3.71 \\
3.97 \\
4.41\end{array}$ & $\begin{array}{l}35,000 \\
39,000 \\
43,000 \\
49,000\end{array}$ \\
\hline
\end{tabular}


3. The specified burnup level and the core fraction calculated in step 2 were used to estimate the enrichment assay. In the domestic fuel management plans for years 1991-1994 for BWR's and 1991-2002 for PWR's, Equations (3) and (4) were used to estimate the enrichment assay. For the remaining years, Equation (7) was used to estimate the change in the enrichment assay, based on the increased burnup and change in core fraction.

4. The amount of uranium to be loaded was calculated as the product of the core fraction computed in step 2 and the total core weight.
5. Two types of adjustments were made to the enrichment assays estimated in step 3: (i) boiling-water reactor enrichments were adjusted downward by a small amount in the post-2000 period, to account for anticipated improvements in fuel utilization; (ii) an enrichment adjustment of +0.2 percent was made to the Japanese enrichments. Japanese utilities have been historically very conservative when ordering nuclear fuel and have typically loaded fuel in their reactors with higher reactivity levels than customarily loaded in the West to obtain comparable burnup levels. This phenomenon is also evident in the higher U-235 enrichment content of the discharged fuel. 


\title{
Appendix C
}

\author{
Nuclear Fuel Cycle
}

Facilities That Prepare Fuel for Nuclear

Power Plants 


\section{Appendix C}

\section{Nuclear Fuel Cycle Facilities That Prepare Fuel for Nuclear Power Plants}

Table C1. Nuclear Fuel Cycle Facilities That Prepare Fuel for Nuclear Power Plants

\begin{tabular}{|c|c|c|c|}
\hline \multicolumn{4}{|c|}{ Uranium Hexafluoride Conversion Facilities ${ }^{b}$} \\
\hline United States & $\begin{array}{l}\text { Allied Corporation } \\
\text { Sequoyah Fuels Company } \\
\text { (GA Technologies) }\end{array}$ & $\begin{array}{l}\text { Metropolis, Illinois } \\
\text { Gore, Oklahoma }\end{array}$ & $\begin{array}{r}12,700 \mathrm{MTU} / \text { year } \\
9,090 \mathrm{MTU} / \text { year }\end{array}$ \\
\hline$\ldots \ldots \ldots$ & $\begin{array}{l}\text { COMURHEX } \\
\text { COMURHEX } \\
\text { COMURHEX }\end{array}$ & $\begin{array}{l}{ }^{\mathrm{E}} \text { Malvesi } \\
\text { 'Pierrelatte } 1 \\
{ }^{9} \text { Pierrelatte } 2\end{array}$ & $\begin{array}{r}14,000 \mathrm{MTU} / \text { year } \\
14,000 \mathrm{MTU} / \text { year } \\
350 \mathrm{MTU} / \text { year }\end{array}$ \\
\hline 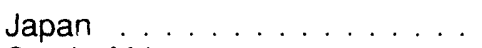 & PNC & Ningyo Pass & $200 \mathrm{MTU} /$ year \\
\hline South Africa . . . . . . . . & $\mathrm{AEC}$ & Valindaba & $1,400 \mathrm{MTU} /$ year \\
\hline $\begin{array}{l}\text { United Kingdom } \ldots \ldots \ldots \ldots \\
\text { U.S.S.R. . . . . . . . . . . }\end{array}$ & $\begin{array}{l}\text { British Nuclear Fuels, Ltd. } \\
\text { Techsnabexport }\end{array}$ & $\begin{array}{l}\text { Springfields, Lancashire } \\
--\end{array}$ & $\begin{array}{r}5,500 \mathrm{MTU} / \text { year } \\
14,000 \mathrm{MTU} / \text { year }\end{array}$ \\
\hline \multicolumn{4}{|c|}{ Uranium Enrichment Facilities ${ }^{\mathrm{h}}$} \\
\hline \multirow{10}{*}{ 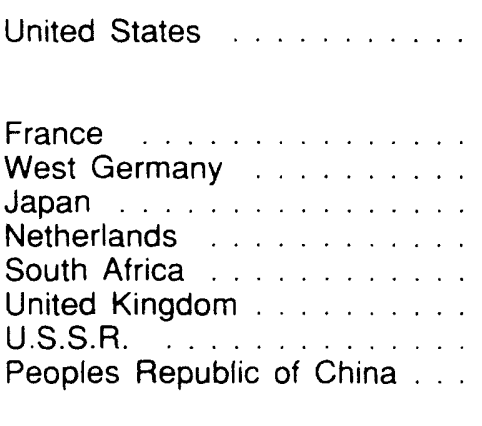 } & U.S. Department of Energy & Oak Ridge, Tennessee & -. \\
\hline & $\begin{array}{l}\text { U.S. Department of Energy } \\
\text { U.S. Department of Energy }\end{array}$ & & $\begin{array}{r}19,300 \text { MTSWU/year } \\
7,900 \text { MTSWU/year }\end{array}$ \\
\hline & EURODIF & Tricastia & 10,800 MTSWU/year \\
\hline & Urenco & Gronau & 400 MTSWU/year \\
\hline & PNC & Ningyo Toge & 260 MTSWU/year \\
\hline & Urenco & Almelo & 1,225 MTSWU/year \\
\hline & AEC & Valindaba & 100 MTSWU/year \\
\hline & Urenco & Capenhurst & 850 MTSWU/year \\
\hline & $\begin{array}{l}\text { Techsnabexport } \\
\text { China Nuclear Eneray }\end{array}$ & -- & 10,000 MTSWU/year \\
\hline & Industry Corporation & -- & $500 \mathrm{MTSWU} /$ year \\
\hline
\end{tabular}

See footnotes at end of table. 
Table C1. Nuclear Fuel Cycle Facilities That Prepare Fuel for Nuclear Power Plants (Continued)

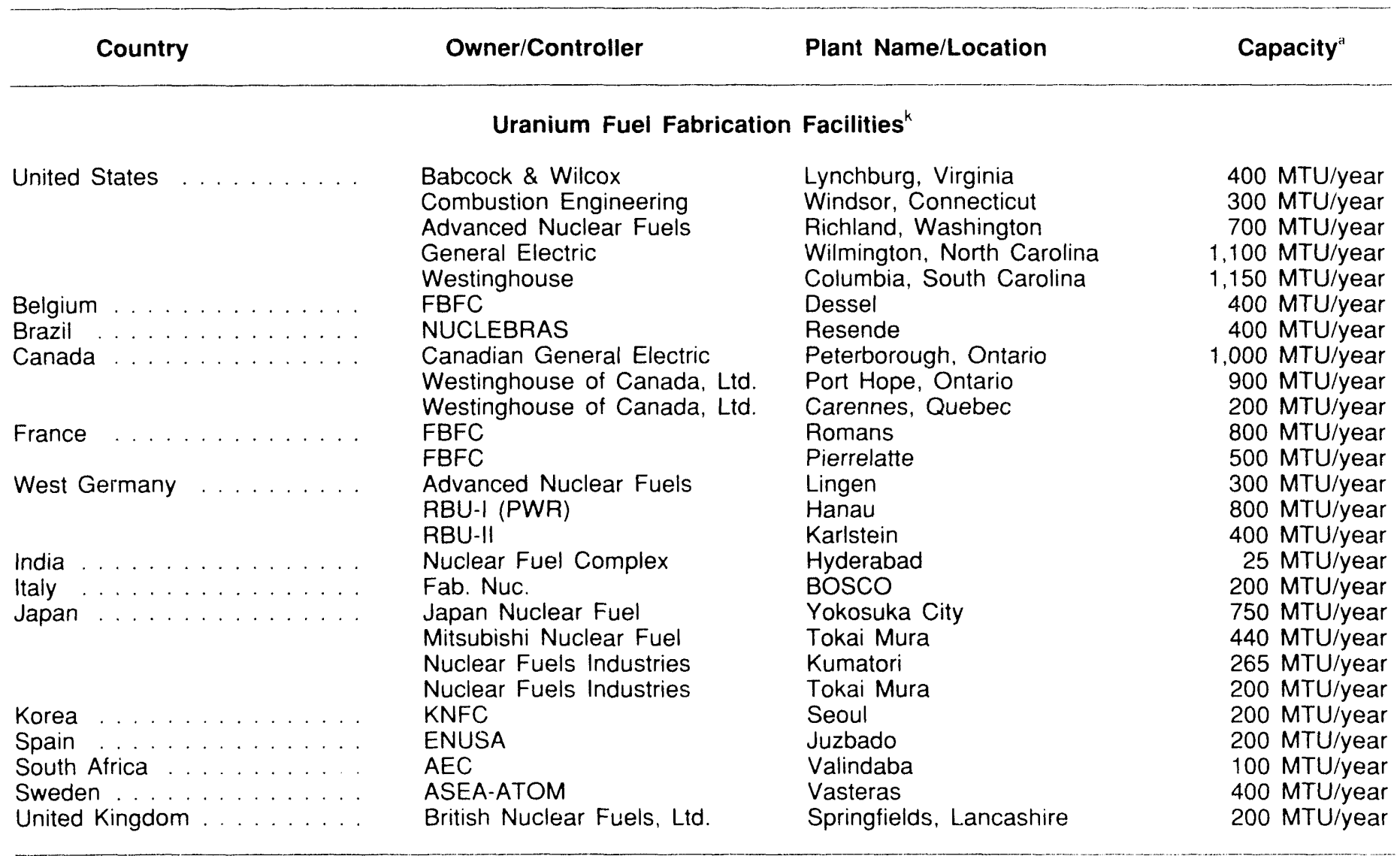

Note: This table includes the main facilities that prepare fuel for nuclear power plants. It does not include auxiliary facilities or plants that support these main facilities.

a Status as of February 1991. MTU, metric tons of uranium; MTSWU. metric tons of separative work units.

'Nuclear Assurance Corporation, Fuel-Trac Reports, "UF 6 Status Report" (Atlanta, GA, February 1991).

$\mathrm{UO}_{3}$ to $\mathrm{UF}_{6}$

${ }^{d} \mathrm{U}_{3} \mathrm{O}_{8}$ to $\mathrm{UO}_{3}$.

${ }^{\mathrm{e}} \mathrm{U}_{3} \mathrm{O}_{8}$ to $\mathrm{UF}_{4}$.

${ }^{1} U \mathrm{~F}_{4}$ to $U \mathrm{~F}_{6}$.

${ }^{9}$ Conversion of reprocessed (irradiated) $\mathrm{UO}_{3}\left(\mathrm{NO}_{3}\right)_{2}$ to $\mathrm{UF}_{6}$.

"Nuclear Assurance Corporation, Fuel-Trac Reports, "Enrichment Status Report" (Atlanta, GA, February 1991).

'This facility, which had been on standby since 1986, was closed on December 15, 1987

U.S. Department of Energy, Office of the Assistant Secretary for Nuclear Energy.

"Nuclear Assurance Corporation, Fuel-Trac Reports, "LWR Fabrication Status Report" (Atlanta, GA, February 1991). 
Appendix D

Projections of U.S. Spent Fuel Discharges, 1991-2040 


\section{Appendix D}

\section{Projections of U.S. Spent Fuel Discharges, 1991-2040}

The projections contained in this appendix were developed in accordance with the assumptions detailed in Appendix B. Table D1 provides annual projections of spent fuel discharges in the United States for each of the nuclear supply scenarios and three burnup sensitivity cases. The cumulative totals are contained in Table D2. The projected average discharge burnup of the spent fuel for equilibrium cycles only is shown in Table D3. Table D4 contains average burnup of spent fuel discharged for all cycles. The projections for the No New Orders case are extended beyond 2030 to estimate the total spent fuel when all nuclear generating units are retired. The year 2040 is the last vear in which fuel is projected to be discharged in the No New Orders case.

Projections of spent fuel discharges for all the nuclear supply scenarios were developed using the base case burnup assumptions shown in Appendix B, Table B3.

The alternative scenarios for spent fuel discharges assume (1) Lower-Reference-case capacity levels with less increase in burnup beyond current levels, (2) Lower-Reference-case capacity levels with continued increases in burnup to 46,000 for BWR's and 60,000 for PWR's by 2010, (3) No New Orders with less increase in burnup above current levels, and (4) No New Orders with continued increase in burnup similar to that described in (3).

In addition to displaving aggregate spent fuel projections shown in Tables D1 and D2, disaggregated projections are presented for each fuel cycle of each nuclear reactor in Tables D5 through D9.

Under the Nuclear Waste Policy Act of 1982, as amended, the L.S. Department of Energy is responsible for developing the waste disposal system for spent nuclear fuel and high-level radioactive waste. To plan for an effective waste management program, the Office of Civilian Radioactive Waste Management (OCRWM) needs to know the range and distribution of charactiristics of the spent fuel expected to be received by the Cinvernment. Hence, OCRWM requires disaggregate spent fuel projections (that is, for individual reactors) for use in waste stream analyses and logistics planning. Since the International Nuclear Model (INM) forecasts are predicated on generic eactor types, there are no differences in the spent fuel forecasts for individual reactors of the same generic type, other than linear scaling of spent fuel discharges to reactor size and differences in capacity factors.

The Energy Information Administration (EIA) administers Form RW-859, "Nuclear Fuel Data," which is used to collect data from U.S. utilities on projected spent fuel discharges. These data are processed by EIA and incorporated into the Integrated Nuclear Information System (INIS). The data from INIS form the basis for disaggregate spent fuel forecasts.

The EIA uses the INM to project aggregate spent fuel discharges and electricity generation for domestic nuclear reactors. These forecasts are based on the operating characteristics of generic boiling-water reactors and pressurized-water reactors. To produce the forecasts, EIA develops a set of operational assumptions for capacity factors, fuel burnup levels, and installed nuclear capacity, as described in the body of this report, and uses a set of generic fuel management plans for boiling-water reactors and pressurized-water reactors, as described in Appendix B. Estimates of nuclear fuel cycle trends are determined by surveving utilities, fuel vendors, and other industry experts. The fuel management plans for the INM are derived statistically from historical operating data and from utilities' projected fuel management schemes.

The utility projections supplied on Form RW-859 are for only the upcoming five fuel cycles and $d$ o not cover the entire forecast period covered by EIA projections. Moreover, there are some differences between the aggregate assumptions inherent in the utility projections and those used by EIA, so that there are differences between the totals in the two sets of projections. This divergence occurs for two reasons. First, utilities are optimistic in their planning and do not take into account unanticipated outages. Second, utilities project only five fuel cycles into the future. This period covers only the first part of the time frame over which EIA assume's an increasing trend in the burnup level of discharged spent fuel. Indered, many utilities have indicated that they are investigating plans for discharge burnup levels that would be higher than those reported on form $R W-x=9$ 
To reconcile the differences between the INM and INIS forecasts, EIA has developed a disaggregate spent fuel forecasting program, DISACi, which calibrates the reactor-specific projections made by the utilities to the aggregate INM projections. The calibration methodology preserves the INM aggregate projections of annual spent fuel discharge's and electricity generation by adjusting the utilities' reactorspecific projections of capacity factors and fuel burnup levels. The methodology also preserves the nature and shape of the burmup distributions projected by the utilities.

\section{Overview}

To understand the methodology used in disaggregating the aggregate forecasts, it is instructive to look at the factors used to make the aggregate INM forecasts, and to highlight the differences between the aggregate and reactor-specific assumptions. In the aggregate INM forecasts, domestic reactors are divided into two major categories-boiling-water reactors and pressurizedwater reactors-and average operating characteristics are assumed for the individual reactors in each category. This formalism facilitates the statistical representation of unplanned outages by using a svstemwide capacity factor for each reactor type, based on actual operating experience. While statistical techniques are appropriate for systemwide analysis, it is not possible to predict unplanned outages for individual reactors. Reactor operations projected by utilities $d o$ not, as a rule, account for unanticipated problems. Consequently, they assume a significantly more efficient systemwide operating environment than has been achieved in the recent past.

In the INM, reactor fuel management plans are defined at the cucle level, whereas utilities project at the batch level. (A batch is a group of assemblies with similar characteristics, such as initial loading weight and enrichment, and discharge burnup.) Consequently, each reactor discharge is characterized in the utility projections by a range of burnup levels. The utilities also project reactor full-power dave and cvele shutdown times, which implicitly determine capacity factors (full-power days divided by cycle length)

The development of the disaggregating methodolegy was guided by the following objective's:

- The methedology must preserve the aggregate energy and spent fuel projections of the INM forecasts.

- It must maintain, to the extent possible, the fuel management projections made by the utilities, epecially with regard to burnup distributions.
- Any adjustments to individual utility forccasts must be explainable in terms of differences between the aggregate burnup and capacity factor assumptions used in the INM forecasts and those used by the utilities.

The INM forecasts are predicated on assumptions about trends in discharge burnup levels and reactor capacity factors. For a given level of installed nuclear capacity, the capacity factor assumptions determine the amount of energy produced, while burnup assumptions determine the quantity of spent fuel that will be generated in producing that energy. Energy production, fuel burnup, and spent fuel generation are functionally related by the following eyuation:

$$
\text { ENERGY = BURNUP } \times \text { SPENT FUEI }
$$

Given any two variables in the above equation, the third variable is uniquely determined. Thus, the objective of preserving the energy and spent fuel projections of the INM forecasts is equivalent to preserving the burnup and capacity factor assumptions used for the INM forecasts.

\section{Capacity Factors}

In the INM, capacity factors are the primary determinant of energy production, which is modeled by the following equation:

$$
\begin{aligned}
\text { INIRGY }= & \text { INSTALIID CAPACITY } \\
& \times \text { CAPACITY FACTOR } \times \text { TIME }
\end{aligned}
$$

FIA scenarios are based on assumptions about trends in capacity factors, which are derived from current capacity factors. To determine the current capacity factors for operating reactors, EIA has statistically analyzed historical reactor operating experience and derived capacity factors representative of the domestic nuclear power industry as a whole. (Boiling-water reactors and pressurized-water reactors are treated separately.) These aggregate capacity factors adequately represent the domestic industry as a whole, since there are a sufficient number of operating reactors to statisticaliv capture unplanned outages on a systemwide basis. Individual reactors, however, exhibit a broad range of operating elficiencies, and an aggregate capacity factor does not represent any single reactor.

Consequently, EIA has stratified reactors with sufficient operating history into capacity factor groups. Eight groups have been defined-four for boilingwater reactors and four for pressurized-water reactors. The groups are defined on the basis of their average capacity factor characteristics: low, medium, high, and very high. The assignment of capacity factors to each group is based on the historical performance of the 
reactors in the group. It is important to note that the aggregate capacity factor for each group, derived from the historical capacity factors for the individual reactors assigned to the group, is consistent with the systemwide aggregate capacity factor

For modeling purposes, a reactor's energy production is determined by its capacity factor. As a result, the assumptions used by EIA for the different capacity factor groups also stratify reactor energy production. These assumptions carry over directly to the disaggregation process.

As noted above, the capacity factors implicit in utility projections are generally optimistic and do not include allowances for unplanned outages. In the aggregate, the utilities' projected capacity factors exceed recent historical capacity factors by 15 to 20 percent. For individual reactors, the relationship between historical and projected capacity factors is very erratic. For 2 reactors the projected capacity factors are less than historical values, and for 85 reactors the projected capacity factors are 2 to 140 percent higher than historical values.

\section{Burnup}

On Form RW-859, utilities project discharge burnup levels for the next five cycles of reactor operation. With the objective of preserving aggregate energy and spent fuel projection from the INM, the fuel management projections made by the utilities on form RW-859, especially with regard to burnup distribution are used to project reactors specific spent fuel discharges. The ElA burnup sensitivity cases study alternative trends in increased burnup, which also vary from the burnup trends in the utility-propagated data.

The ElA base case assumes a continuing increase in burnup levels beyond those inherent in the utility data, with the design equilibrium burnups reaching $4(0,600)$ megawattdays thermal per metric ton of initial heary metal for boiling-water reactors in 20000 and $45,(1)()$ megawattdays thermal per metric ton of initial heary metal for pressurized-water reactors around 1997 .

\section{Adjustment Procedure}

In the disaggregation procedure, each reactor is assumed to operate with the capacity factor assigned to it in the INM forecast. That is, each reactor's energy production is determined by its capacity factor in the INM. The disaggregate adjustments for spent fuel discharges and burnup levels are made for individual reactors in the energy or full-power-day demain. When the full-power-day domain is used, ne adjustments are required for energy production, and the objective of preserving the encrgy production levels from the INM is autematically satisfied.
To reconcile the differences between annual burnup levels in the utility data and in the INM forecast, a set of annual adjustment factors is developed to bring the utility projections in line with the INM forecasts by comparing annual spent fuel forecasts from the two data series. Discharge burnups are adjusted inversely to the adjustments in spent fuel discharges, keeping energy generation constant.

As noted above, all adjustments are made in the fullpower-day or energy domain, to yield a simple interpretation of the adjustments made for individual reactors. Annual adjustment factors are essentially the ratio of mean annual discharge burnups from the utility data to those from the INM forecasts. For instance, if the utility data indicate a mean discharge burnup level for pressurized-water reactors of $39,0(0)$ megawattdays thermal per metric ton of initial heavy metal and the INM forecast show's a mean discharge burnup level of 43,000 megawattdays thermal per metric ton of initial heavy metal for a given year, the amount of fuel discharged from the reactor is adjusted downward by about 10 percent, and the discharge burnup of each batch is adjusted upward by about 10 percent for that year. Initial fuel enrichment levels are also adjusted when burnups are adjusted. The adjustments to enrichment levels are based on the formulas given in Appendix $C$.

\section{Near-Term Use of Utility Data}

Much of the fuel scheduled to be discharged over the next three or four cycles has already been loaded into the reactors or, at least, firmly ordered. It is fell that the utilities can make the best projections of the amounts and burnup levels of spent fuel discharges for this period. Therefore, the utility data are used directly for near-term disaggregate forecasts. I lowever, since the capacity factors implied by the utility data are significantly overestimated in comparison with the EIA assumptions, they are not used. Rather, cycle lengths are derived by dividing the number of fullpower days by the capacity factor assigned by EIA. The date of the first projected discharge for each reactor in the INM database is set to the date provided by the utility.

\section{Generic Reactors}

Some EIA projections include data for generic or as yet unidentified reactors that are projected to come on line after the year $20(0)$. Since these are hypothetical reactors, there are no utility projections for their fuel management plans. Therefore, the discharges assigned to these reactors are derived from the generic fuel management plans used in the INM. That is, only existing reactors are subject to the disaggregation procedure 
Table D1. Projections of Annual U.S. Spent Fuel Discharges, 1991-2040

(Thousand Metric Tons of Heavy Metal)

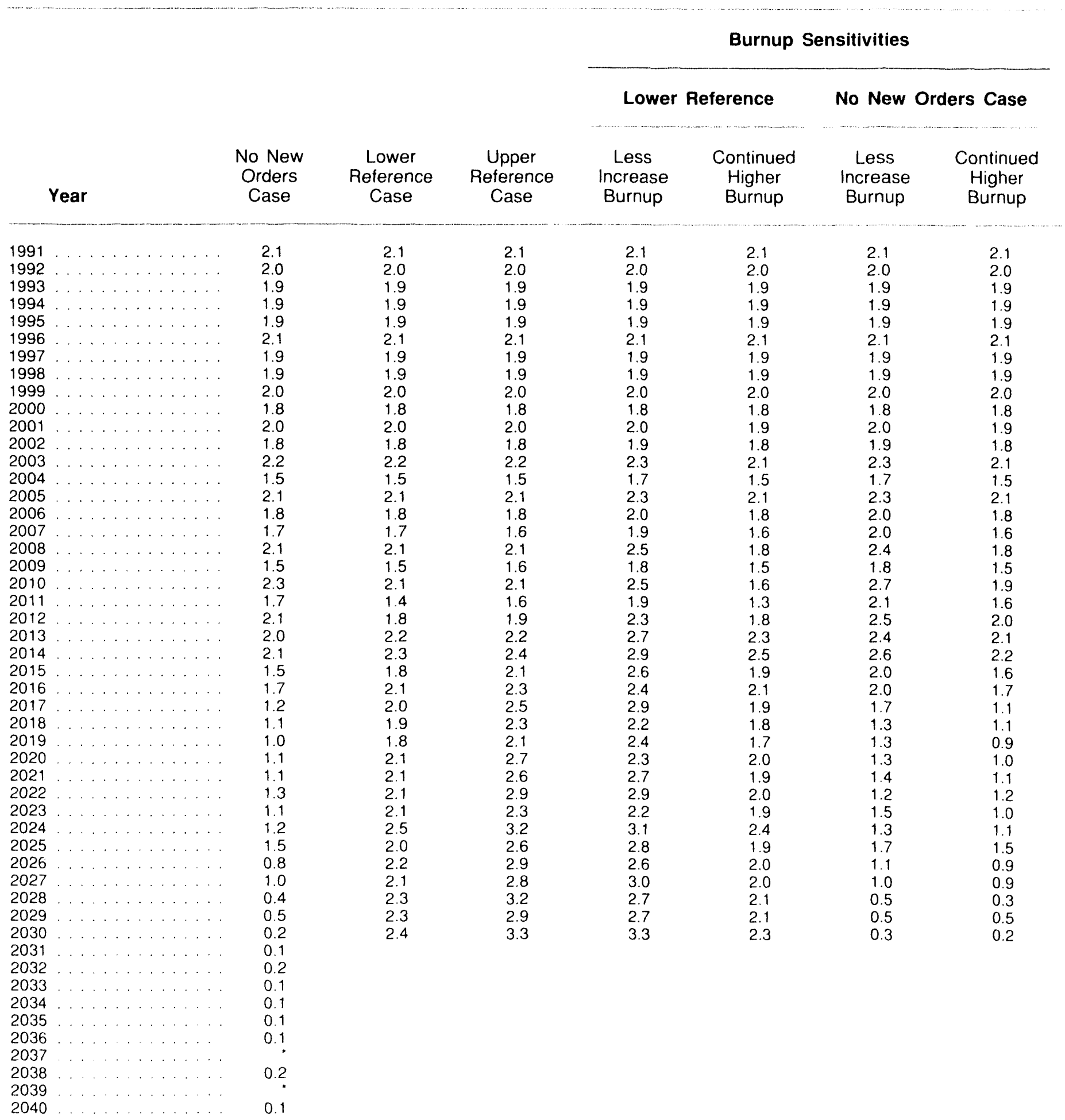

"No spent fuel discharges for year or discharges less than 50 Metric tons.

Source: Projections derived from the International Nuclear Model Form RW-859, "Nuclear Fuel Data" (1990). 
Table D2. Projections of Total U.S. Spent Fuel Discharges, 1991-2040

(Thousand Metric Tons of Heavy Metal)

Burnup Selısitivities

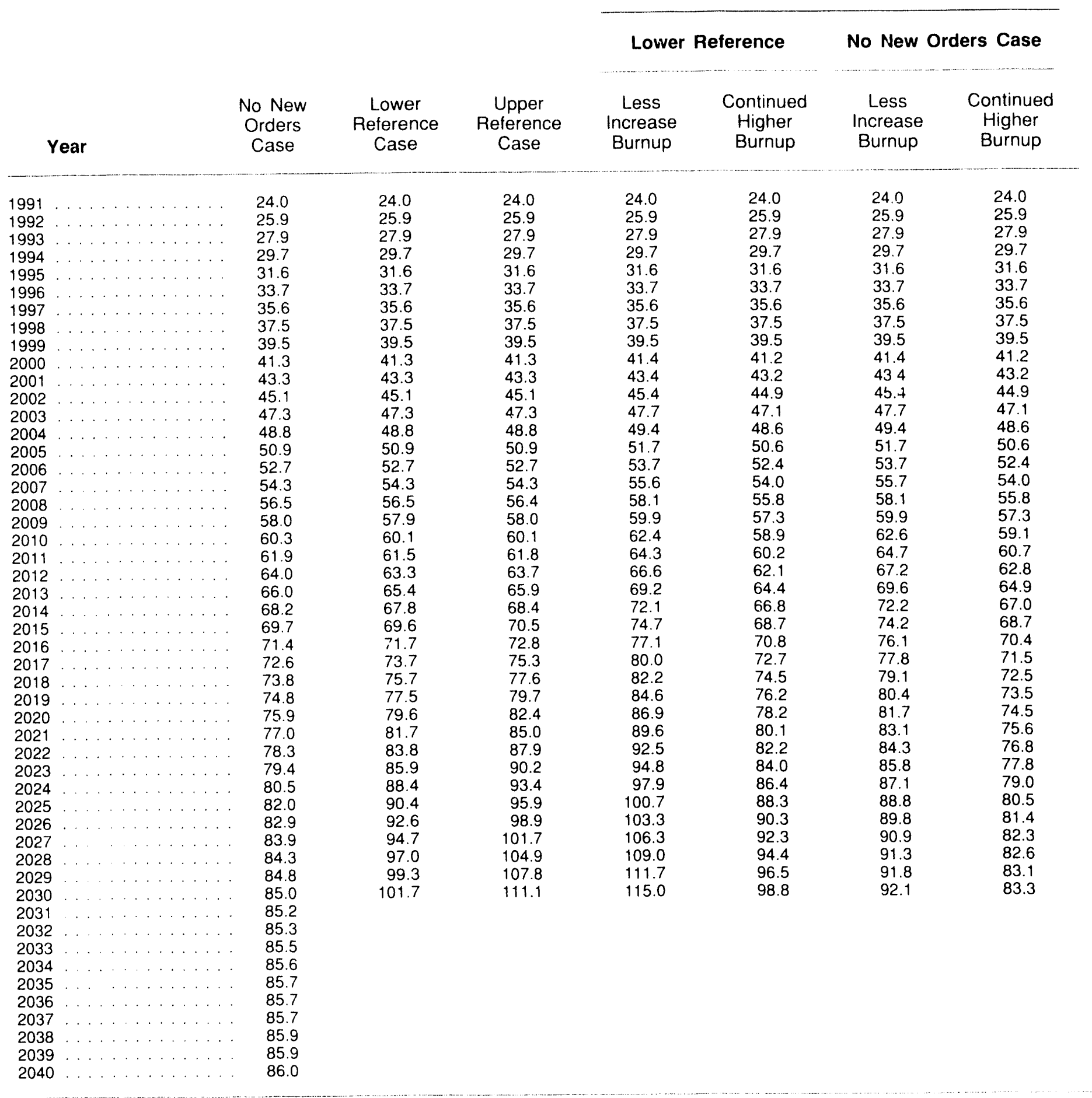

Source: Projections derived from the International Nuclear Model Form RW-859, "Nuclear Fuel Data" (1990). 
Table D3. Projected Average Annual Burnup of Spent Fuel Discharges by U.S. Nuclear Power Plants for Equilibrium Cycles, 1991-2030

(Megawattdays Thermal per Metric Ton of Initial Heavy Matal)

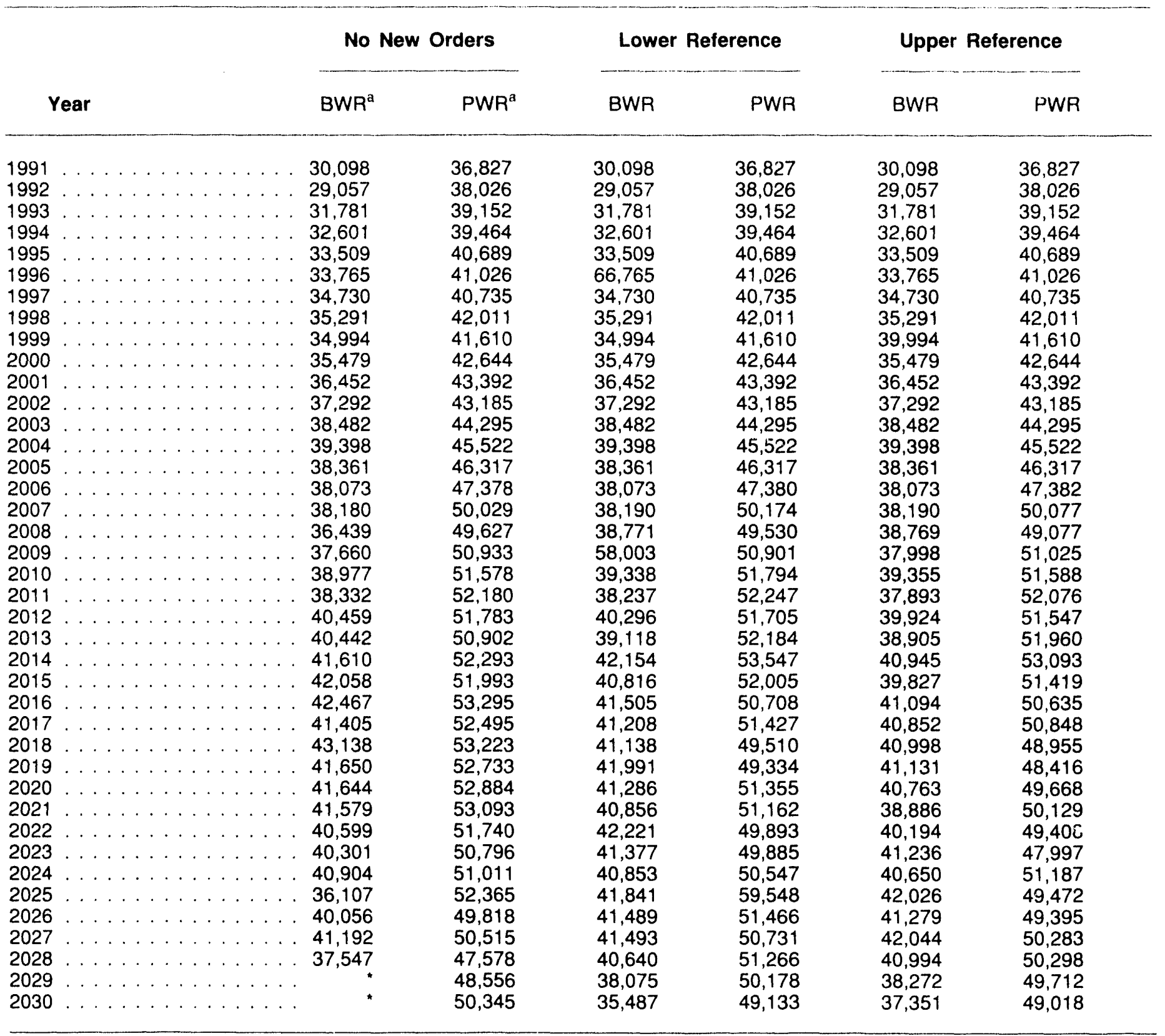

${ }^{\mathrm{a}} \mathrm{BWR}=$ Boiling water reactor; PWR = Pressurized water reactor.

"No spent fuel discharges for BWR's for the year.

Source: Projections derived from the International Nuclear Model Form RW-859, "Nuclear Fuel Data" (1990). 
Table D4. Projected Average Annual Burnup of Spent Fuel Discharges by U.S. Nuclear Power Plants for All Cycles, 1991-2030

(Megawattdays Thermal per Metric Ton of Initial Heavy Metal)

\begin{tabular}{|c|c|c|c|c|c|c|}
\hline \multirow[b]{2}{*}{ Year } & \multicolumn{2}{|c|}{ No New Orders } & \multicolumn{2}{|c|}{ Lower Reference } & \multicolumn{2}{|c|}{ Upper Reference } \\
\hline & $\mathrm{BWR}^{\mathrm{a}}$ & $\mathrm{PWR}^{\mathrm{a}}$ & BWR & PWR & BWR & PWR \\
\hline$\ldots \ldots \ldots$ & 28,919 & 35,831 & 28,919 & 29,867 & 28,919 & 35,831 \\
\hline$\ldots \ldots \ldots$ & 28,597 & 36,910 & 28,597 & 35,831 & 28,597 & 36,910 \\
\hline$\ldots \ldots$ & 31,781 & 38,414 & 31,871 & 36,910 & 31,781 & 38,414 \\
\hline$\ldots \ldots \ldots$ & 31,813 & 39,133 & 31,813 & 38,414 & 31,813 & 39,133 \\
\hline$\ldots \ldots \ldots$ & 33,509 & 40,157 & 33,509 & 39,133 & 33,509 & 40,157 \\
\hline$\ldots \ldots \ldots \ldots \ldots$ & 33,765 & 40,500 & 33,765 & 40,157 & 33,765 & 40,500 \\
\hline$\ldots \ldots \ldots \ldots$ & 34,730 & 40,357 & 34,730 & 40,500 & 34,730 & 40,357 \\
\hline$\ldots \ldots \ldots \ldots$ & 35,291 & 41,716 & 35,291 & 40,357 & 35,291 & 41,716 \\
\hline$\ldots \ldots \ldots \ldots$ & 34,994 & 41,610 & 34,994 & 41,716 & 34,994 & 41,610 \\
\hline$\ldots \ldots \ldots$ & 36,452 & 43,392 & 36,452 & 41,902 & 30,452 & 43,392 \\
\hline$\ldots \ldots \ldots$ & 36,452 & $43,3,92$ & 36,452 & 41,902 & 36,452 & 43,392 \\
\hline $2002 \ldots \ldots \ldots \ldots \ldots$ & 37,292 & 41,955 & 37,292 & 43,392 & 37,292 & 41,955 \\
\hline $2003 \ldots \ldots \ldots \ldots \ldots$ & 38,134 & 43,906 & 38,134 & 41,955 & 38,134 & 42,906 \\
\hline$\ldots \ldots \ldots$ & 37,398 & 45,522 & 37,398 & 43,906 & 37,398 & 45,522 \\
\hline$\ldots \ldots \ldots \ldots$ & 38,361 & 45,854 & 38,361 & 45,522 & 38,361 & 45,854 \\
\hline$\ldots \ldots \ldots$ & 38,073 & 47,378 & 38,073 & 45,854 & 38,073 & 47,382 \\
\hline$\ldots \ldots \ldots$ & 38,180 & 47,489 & 38,190 & 47,380 & 38,190 & 48,188 \\
\hline$\ldots \ldots \ldots$ & 38,439 & 49,627 & 38,771 & 48,369 & 38,040 & 49,182 \\
\hline$\ldots \ldots \ldots \ldots$ & 33,715 & 50,166 & 34,115 & 49,530 & 33,260 & 50,088 \\
\hline$\ldots \ldots \ldots$ & 36,288 & 50,050 & 39,324 & 50,901 & 38,084 & 49,855 \\
\hline$\ldots \ldots \ldots \ldots$ & 33,544 & 50,087 & 38,237 & 50,767 & 34,621 & 49,296 \\
\hline$\ldots \ldots \ldots \ldots$ & 33,954 & 49,383 & 37,999 & 50,032 & 36,346 & 50,279 \\
\hline$\ldots \ldots \ldots$ & 35,454 & 44,607 & 34,958 & 51,144 & 34,442 & 44,460 \\
\hline $2014 \ldots \ldots \ldots \ldots \ldots$ & 30,604 & 47,707 & 33,126 & 44,690 & 33,058 & 43,926 \\
\hline $2015 \ldots \ldots \ldots \ldots$ & 36,868 & 48,398 & 37,805 & 44,959 & 37,438 & 43,394 \\
\hline $2016 \ldots \ldots \ldots \ldots$ & 36,007 & 48,889 & 41,505 & 45,233 & 41,094 & $43,4 \dddot{76}$ \\
\hline $2017 \ldots \ldots \ldots \ldots \ldots$ & 41,405 & 50,737 & 38,869 & 44,842 & 39,017 & 44,335 \\
\hline$\ldots \ldots \ldots \ldots$ & 39,665 & 49,503 & 41,138 & 47,527 & 40,998 & 43,356 \\
\hline$\ldots \ldots \ldots \ldots$ & 41,650 & 52,733 & 41,991 & 46,381 & 41,131 & 43,837 \\
\hline$\ldots \ldots \ldots \ldots$ & 41,644 & 50,912 & 41,268 & 46,784 & 40,763 & 46,141 \\
\hline 2021 & 41,579 & 48,729 & 40,856 & 49,199 & 38,886 & 44,928 \\
\hline 2022 & 34,096 & 48,599 & 42,221 & 47,086 & 40,194 & 45,686 \\
\hline 2023 & 40,301 & 46,411 & 41,377 & 46,070 & 41,236 & 43,564 \\
\hline$\ldots \ldots \ldots$ & 29,894 & 48,275 & 37,748 & 45,582 & 38,061 & 47,373 \\
\hline 2025 & 29,074 & 43,880 & 41,841 & 47,584 & 42,026 & 45,890 \\
\hline 2026 & 29,001 & 43,703 & 41,489 & 46,824 & 41,279 & 45,739 \\
\hline 2027 & 29,785 & 40,881 & 41,493 & 48,398 & 42,044 & 46,387 \\
\hline 2028 & 37,547 & 41,042 & 37,426 & 47,784 & 37,979 & 47,099 \\
\hline $2029 \ldots \ldots \ldots \ldots$ & 22,472 & 41,019 & 38,075 & 48,644 & 38,272 & 46,003 \\
\hline $2030 \ldots \ldots \ldots \ldots$ & & 36,168 & 29,867 & 47,874 & 31,522 & 46,633 \\
\hline
\end{tabular}

${ }^{\mathrm{a}} \mathrm{BWR}=$ Boiling water reactor; PWR = Pressurized water reactor

"No spent fuel discharges for BWR's for the year.

Source: Projections derived from the International Nuclear Model Form RW-859, "Nuclear Fuel Data" (1990). 
Table D5. Projected Spent Fuel Discharges by U.S. Reactors in the No New Orders Case, 1991-2001 (Metric Tons of Initial Heavy Metal)

\begin{tabular}{|c|c|c|c|c|c|c|c|c|c|c|c|}
\hline Unit & 1991 & 1992 & 1993 & 1994 & 1995 & 1996 & 1997 & 1998 & 1999 & 2000 & 2001 \\
\hline Arkansas Nuclear $1 \ldots$. . . & & 28 & - & 28 & - & 30 & - & 30 & - & 29 & - \\
\hline Arkansas Nuclear $2 \ldots \ldots$ & 28 & 28 & - & 28 & - & 28 & - & 28 & - & 27 & 27 \\
\hline Beaver Valley $1 \ldots \ldots$ & 34 & - & 34 & & 32 & - & 32 & - & 31 & & 30 \\
\hline Beaver Valley $2 \ldots \ldots \ldots$ & - & 32 & - & 32 & - & 31 & - & 31 & . & 30 & - \\
\hline Bellefonte $1 \ldots$ & - & . & - & . & - & - & - & - & - & 28 & - \\
\hline$\ldots \ldots$ & - & - & - & - & - & - & - & - & - & . & - \\
\hline$\ldots \ldots \ldots$ & 3 & & 3 & 3 & 3 & 3 & 3 & 3 & & 3 & 2 \\
\hline$\ldots \ldots \ldots$ & 36 & 36 & & 36 & - & 36 & 36 & - & 35 & & 34 \\
\hline Braidwood $2 \ldots \ldots \ldots$ & 36 & - & 32 & - & 34 & - & 34 & - & 34 & 33 & . \\
\hline Browns Ferry $1 \ldots \ldots \ldots$ & - & - & - & - & - & - & - & 41 & - & 39 & 35 \\
\hline Browns Ferry $2 \ldots \ldots \ldots$ & 36 & - & 32 & - & 34 & - & 34 & - & 34 & 33 & - \\
\hline Browns Ferry $3 \ldots \ldots \ldots$ & - & - & - & 40 & - & 38 & - & 37 & - & 36 & - \\
\hline Brunswick $1 \ldots \ldots \ldots$ & - & 22 & & 27 & - & 26 & - & 27 & - & 23 & - \\
\hline Brunswick $2 \ldots \ldots \ldots$ & 28 & 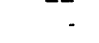 & 28 & . & 28 & - & 28 & - & - & 28 & - \\
\hline$\ldots \ldots \ldots$ & 37 & - & 36 & - & 36 & . & 36 & - & 36 & 35 & - \\
\hline$\ldots \ldots \ldots$ & - & 39 & 37 & - & 37 & - & 37 & - & 37 & - & 36 \\
\hline Callaway $1 \ldots$ & - & 39 & 39 & - & 36 & - & 36 & - & 36 & 35 & - \\
\hline Calvert Cliffs 1 & 36 & - & 34 & - & 34 & - & 34 & - & 34 & . & 33 \\
\hline Calvert Cliffs 2 & - & 35 & - & 34 & - & 34 & . & 34 & & 33 & \\
\hline$\ldots \ldots \ldots$ & 31 & 31 & 32 & - & 32 & 32 & - & 32 & 32 & . & 31 \\
\hline Catawba 2 & 32 & - & 32 & 32 & . & 32 & 32 & - & 32 & 31 & - \\
\hline Clinton $1 \ldots \ldots \ldots \ldots$ & . & 30 & 33 & - & 36 & 36 & . & 34 & 35 & - & 34 \\
\hline Comanche Peak $1 \ldots$ & - & 23 & 24 & 27 & . & 23 & 23 & 23 & 22 & 22 & 22 \\
\hline Comanche Peak $2 \ldots \ldots$ & - & - & . & 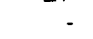 & 27 & 26 & 26 & 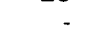 & 27 & 25 & 24 \\
\hline Donald C. Cook 1 & - & 37 & - & 37 & 37 & - & 37 & - & 37 & - & 36 \\
\hline Donald C. Cook 2 . & - & 31 & 31 & - & 31 & - & 31 & - & 31 & - & 30 \\
\hline Cooper Station .......... & 25 & & 31 & - & 25 & - & 28 & 27 & . & 27 & - \\
\hline Crystal River $3 \ldots \ldots \ldots$ & - & 36 & & - & 32 & & - & 32 & . & & 31 \\
\hline Davis-Besse $1 \ldots \ldots \ldots$ & 30 & & 30 & - & - & 28 & - & 30 & - & 27 & \\
\hline Diablo Canyon $1 \ldots \ldots$ & 31 & 31 & . & 31 & - & 34 & . & 43 & 38 & - & 36 \\
\hline Diablo Canyon $2 \ldots \ldots$ & 48 & & 48 & - & 48 & 36 & & 34 & - & 35 & 34 \\
\hline Dresden $2 \ldots \ldots$ & & 30 & & 26 & & 25 & 25 & & 26 & & 24 \\
\hline$\ldots \ldots$ & 27 & & 27 & & 27 & 27 & & 26 & - & 26 & \\
\hline Duane Arnold. & $\therefore$ & 17 & - & 17 & - & 17 & 17 & - & 17 & - & 16 \\
\hline Enrico Fermi $2 \ldots$ & 37 & 31 & 35 & - & 37 & 37 & - & 37 & 36 & - & 35 \\
\hline Joseph M. Farley $1 \ldots \ldots$ & 30 & 30 & & 32 & 30 & - & 30 & . & 30 & 29 & - \\
\hline Joseph M. Fariey $2 \ldots \ldots$ & & 30 & 30 & & 30 & 30 & & 30 & 29 & . & 28 \\
\hline James Fitzpatrick . . . . . . & 37 & . & & 37 & & 37 & - & 37 & 25 & - & 36 \\
\hline Fort Calhoun $\ldots \ldots \ldots$ & 18 & - & 16 & - & 16 & - & 16 & - & 16 & - & 16 \\
\hline Ginna . . . . . . . . . & 11 & 11 & 11 & 11 & 11 & 11 & 11 & 11 & 11 & 11 & 11 \\
\hline Grand Gulf 1 & - & 50 & 50 & - & 50 & - & 50 & 50 & - & 49 & - \\
\hline Haddam Neck .. & 19 & & 18 & 21 & & 19 & 19 & - & 19 & 19 & - \\
\hline Shearon Harris 1 & 28 & 28 & & 28 & & 28 & & 28 & 28 & - & 27 \\
\hline Edwin I. Hatch $1 \ldots \ldots$ & 32 & . & 33 & & 33 & - & 33 & & 32 & - & 31 \\
\hline Edwin 1. Hatch 2 & 33 & - & 33 & - & 34 & - & 33 & - & 33 & 32 & - \\
\hline Hope Creek ... & 49 & 46 & - & 43 & - & 43 & - & 43 & 43 & - & 40 \\
\hline Indian Point $2 \ldots \ldots \ldots$ & 33 & & 33 & - & 33 & - & 33 & - & . & 31 & - \\
\hline Indian Point $3 \ldots \ldots \ldots$ & & 39 & & - & 33 & & & 33 & & & 32 \\
\hline Kewaunee $\ldots \ldots \ldots \ldots$ & 14 & 17 & 15 & 14 & 14 & 14 & 14 & 14 & 14 & 13 & 13 \\
\hline LaSalle City $1 \ldots \ldots \ldots$ & 33 & - & 36 & - & 36 & - & 36 & - & 36 & - & 35 \\
\hline LaSalle City 2 & . & 40 & 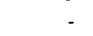 & 37 & - & 37 & - & 37 & 37 & - & 35 \\
\hline Limerick $1 \quad \ldots \ldots \ldots \ldots$ & & 46 & . & 48 & - & - & 48 & 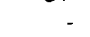 & 48 & - & - \\
\hline Limerick $2 \ldots \ldots \ldots \ldots$ & 47 & - & - & 52 & - & 52 & - & & 51 & & \\
\hline Maine Yankee . . . . . & 21 & - & 26 & - & 23 & 26 & - & 26 & - & 26 & 25 \\
\hline McGuire $1 \ldots \ldots \ldots$ & 33 & - & 32 & 32 & . & 32 & 32 & 32 & - & $3:$ & 31 \\
\hline McGuire 2 & & 32 & 32 & . & - & 32 & . & 31 & 30 & $\because$ & 29 \\
\hline Millstone $1 \ldots$ & 33 & & 33 & & 32 & & 31 & & 31 & 31 & \\
\hline Millstone 2 . . & - & 28 & - & 34 & - & 34 & . & 34 & - & - & 32 \\
\hline$\ldots \ldots \ldots$ & 41 & 44 & - & . & 45 & . & 45 & . & 44 & - & 43 \\
\hline Monticello. & 23 & - & 23 & - & 23 & & 23 & . & 23 & - & 23 \\
\hline
\end{tabular}

See footnote at end of table. 
Table D5. Projected Spent Fuel Discharges by U.S. Reactors in the No New Orders Case, 1991-2001 (Continued)

(Metric Tons of Initial Heavy Metal)

\begin{tabular}{|c|c|c|c|c|c|c|c|c|c|c|c|c|}
\hline Unit & & 1991 & 1992 & 1993 & 1994 & 1995 & 1996 & 1997 & 1998 & 1999 & 2000 & 2001 \\
\hline Nine Mile Point 1 & $1 \ldots \ldots$ & - & 33 & - & - & 31 & - & 32 & - & - & 30 & - \\
\hline Nine Mile Point 2 & $2 \ldots \ldots$ & - & 38 & 28 & - & 29 & 29 & 29 & - & 29 & 29 & 27 \\
\hline North Anna 1 & $\ldots \ldots$ & 34 & & 30 & - & 30 & 30 & . & 30 & - & 29 & . \\
\hline North Anna 2 & $\ldots \ldots$ & - & 32 & . & 32 & 32 & - & 32 & - & 32 & . & 30 \\
\hline Oconee $1 \ldots$ & . . . . & 30 & . & 24 & 28 & . & 28 & - & 28 & - & 27 & 27 \\
\hline Oconee $2 \ldots$ & $\ldots \ldots$ & - & 27 & 28 & . & 28 & & 28 & 28 & - & 27 & 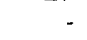 \\
\hline Oconee $3 \ldots$ & $\ldots \ldots$ & 24 & 24 & - & 28 & - & 28 & 26 & - & 27 & . & 2.6 \\
\hline Oyster Creek 1 & $\ldots \ldots$ & 23 & - & - & 32 & - & 31 & - & - & 31 & - & - \\
\hline Palisades .... & $\ldots \ldots$ & - & 30 & - & 27 & - & 24 & - & 30 & . & 26 & - \\
\hline Palo Verde 1 & $\ldots \ldots$ & 39 & - & 39 & 39 & - & 39 & - & 39 & - & 39 & 38 \\
\hline Palo Verde 2 & $\ldots$ & 38 & - & 38 & - & 38 & - & 38 & 37 & - & 37 & . \\
\hline Palo Verde 3 & $\ldots \ldots$ & 50 & 48 & - & 38 & - & 38 & . & 38 & 37 & - & 36 \\
\hline Peachbottom 2 & $\ldots \ldots$ & 39 & - & 52 & - & - & 52 & - & - & 52 & - & - \\
\hline Peachbottom 3 & $\ldots \ldots$ & 48 & - & - & 42 & - & - & 52 & - & - & 52 & - \\
\hline Perry $1 \ldots$ & $\ldots \ldots$ & - & 35 & - & 45 & 48 & - & 48 & - & 46 & 45 & - \\
\hline Pilgrim $1 \ldots$ & $\ldots \ldots$ & 35 & - & - & 36 & - & - & 36 & - & - & 35 & - \\
\hline Point Beach 1 . & $\ldots \ldots$ & 12 & 12 & 12 & 12 & 12 & 12 & 12 & 12 & 12 & 12 & 11 \\
\hline Point Beach 2 . & $\ldots$ & 12 & 12 & 12 & 12 & - & 12 & 12 & 12 & 12 & 11 & - \\
\hline Prairie Island 1 & $\ldots \ldots$ & 17 & 17 & - & 17 & - & 17 & 17 & - & $1 \overline{7}$ & 17 & \\
\hline Prairie Island 2 & $\ldots \ldots$ & - & 19 & 19 & - & 17 & 17 & - & 17 & - & 17 & 16 \\
\hline Quad Cities 1 . & $\ldots \ldots$ & - & 36 & - & 30 & - & 26 & 25 & - & 25 & 24 & - \\
\hline Quad Cities 2 . & $\ldots \ldots$ & 27 & . & 25 & 25 & - & 25 & - & 25 & 25 & - & 25 \\
\hline H.B. Robinson 2 & $2 \ldots \ldots$ & - & 21 & 27 & - & 21 & - & 21 & 21 & - & 21 & - \\
\hline River Bend 1 . & $\ldots \ldots$ & - & 37 & 38 & - & 38 & - & 38 & 38 & - & 37 & 36 \\
\hline Salem $1 \ldots$ & $\ldots \ldots$ & 41 & 37 & - & 31 & - & 39 & - & 34 & - & 35 & - \\
\hline Salem $2 \ldots$ & $\ldots \ldots$ & 35 & - & 45 & - & - & 35 & - & 37 & - & - & 38 \\
\hline San Onotre 1 & $\ldots \ldots$ & - & 24 & - & . & 24 & - & - & 24 & - & - & 23 \\
\hline San Onofre 2 & $\ldots \ldots$ & 44 & - & 44 & - & 44 & - & 44 & - & 44 & - & 43 \\
\hline San Onofre 3 & $\ldots \ldots$ & - & 44 & - & 44 & - & 44 & - & 44 & - & 43 & - \\
\hline Seabrook $1 \ldots$ & $\ldots \ldots$ & - & 28 & 41 & - & 37 & - & 37 & - & 37 & - & 36 \\
\hline Sequoyah $1 \ldots$ & $\ldots \ldots$ & 31 & - & - & 31 & - & 31 & - & 31 & - & 06 & - \\
\hline Sequoyah 2 & $\ldots \ldots$ & - & 31 & - & 31 & - & 31 & - & - & 29 & - & 29 \\
\hline South Texas 1 & $\ldots \ldots$ & 41 & - & 39 & 37 & - & 37 & - & 37 & - & 35 & - \\
\hline South Texas 2 & $\ldots$ & 43 & - & 43 & - & 32 & - & 38 & - & 38 & - & 37 \\
\hline St. Lucie $1 \ldots$ & $\ldots \ldots$ & 32 & - & 28 & 29 & . & 26 & 29 & - & 27 & 26 & - \\
\hline St. Lucie $2 \ldots$ & $\ldots \ldots$ & - & 29 & 28 & - & 28 & 28 & - & 28 & - & 27 & 27 \\
\hline Sumimer $1 \ldots$ & $\ldots \ldots$ & 32 & - & 32 & 32 & - & 32 & - & 32 & 31 & . & 30 \\
\hline Surry $1 \ldots$ & $\ldots \ldots$ & - & 52 & - & 24 & 24 & . & 24 & . & 24 & - & 24 \\
\hline Surry $2 \ldots$ & $\ldots \ldots$ & 30 & . & 19 & - & 24 & - & 24 & - & 24 & - & 24 \\
\hline Susquehanna 1 & $\ldots \ldots$ & - & 38 & 38 & - & 38 & 38 & - & 38 & 38 & - & 36 \\
\hline Susquehanna 2 & $\ldots \ldots$ & 41 & 39 & - & 39 & - & 39 & 39 & - & 39 & 38 & \\
\hline Trojan ...... & $\ldots \ldots$ & 24 & 34 & 32 & 32 & 18 & 25 & - & 25 & 25 & 24 & 24 \\
\hline Turkey Point 3 & $\ldots \ldots$ & - & 22 & - & 20 & - & 20 & . & 20 & 19 & - & 19 \\
\hline Turkey Point 4 & $\ldots \ldots$ & - & - & 20 & . & 20 & 20 & - & 20 & 19 & - & 19 \\
\hline Vogtle $1 \ldots$ & $\ldots$ & 33 & - & 32 & - & 45 & - & - & 45 & - & 37 & - \\
\hline Vogtle $2 \ldots$ & $\ldots \ldots$ & - & 33 & - & 39 & - & 37 & - & 37 & - & - & 37 \\
\hline Vermont Yankee & e $1 \ldots$ & . & 23 & 23 & . & 23 & - & 23 & 23 & - & 22 & . \\
\hline Washington Nucl & clear $2 \ldots$ & 37 & 24 & 23 & 23 & 23 & 23 & 23 & 23 & 23 & 23 & 22 \\
\hline Waterford 3 & $\ldots$ & 35 & 35 & - & 35 & 35 & - & 35 & 35 & . & 34 & 33 \\
\hline Watts Bar 1 & $\ldots \ldots$ & - & & - & 31 & - & 30 & 30 & - & 30 & 29 & . \\
\hline Watts Bar ... & $\ldots \ldots$ & - & - & - & - & - & - & 31 & 29 & - & 28 & 28 \\
\hline Wolf Creek 1 & $\ldots \ldots$ & 39 & - & 39 & - & 37 & - & 37 & - & 37 & . & 36 \\
\hline Yankee-Rowe 1 & $\ldots \ldots$ & - & 8 & - & 9 & 9 & - & 8 & - & 9 & 18 & . \\
\hline Zion $1 \ldots$ & $\ldots \ldots$ & 22 & 33 & - & 37 & . & 35 & 35 & - & 34 & - & 33 \\
\hline Zion $2 \ldots$ & $\ldots \ldots$ & 35 & - & 33 & & 33 & 33 & - & 33 & - & 32 & 32 \\
\hline 3 Mile Island 1 & $\ldots \ldots$ & 35 & - & - & 41 & - & 36 & - & . & 36 & . & 35 \\
\hline BWR Subtotal & $\ldots \ldots$ & 656 & 652 & 590 & 684 & 592 & 681 & 739 & 541 & 793 & 573 & 494 \\
\hline PWR Subtotal & $\ldots \ldots$ & 1.434 & 1.338 & 1,323 & 1,193 & 1,275 & 1,380 & 1.150 & 1,399 & 1,227 & 1,229 & 1.462 \\
\hline Total ...... & $\ldots \ldots$ & 2.090 & 1.990 & 1.913 & 1,877 & 1,867 & 2,061 & 1.890 & 1.940 & 2,020 & 1.802 & 1,956 \\
\hline
\end{tabular}

Source: Projections derived from the International Nuclear Model and Form RW-859, "Nuclear Fuel Data" (1990). 
Table D6. Projected Spent Fuel Discharges by U.S. Reactors in the No New Orders Case, 2002-2011 (Metric Tons of Initial Heavy Metal)

\begin{tabular}{|c|c|c|c|c|c|c|c|c|c|c|}
\hline Unit & 2002 & 2003 & 2004 & 2005 & 2006 & 2007 & 2008 & 2009 & 2010 & 2011 \\
\hline Arkansas Nuclear $1 \ldots \ldots$ & 29 & 28 & - & 26 & - & 25 & $\dot{-}$ & 24 & & 24 \\
\hline Arkansas Nuclear $2 \ldots \ldots$ & & 26 & - & 26 & & 25 & 23 & - & 23 & \\
\hline Beaver Valley $1 \ldots \ldots \ldots$ & 30 & - & 29 & - & 28 & - & 27 & - & 25 & - \\
\hline Beaver Valley 2 & 30 & - & 28 & 28 & - & 27 & - & 26 & - & 25 \\
\hline Bellefonte 1 & 32 & 37 & .. & 34 & - & 33 & - & 31 & 31 & - \\
\hline$\ldots \ldots \ldots$ & - & - & - & 26 & - & 29 & 32 & . & 31 & . \\
\hline$\ldots \ldots \ldots \ldots$ & 2 & 11 & - & - & - & & . & - & . & - \\
\hline Braidwood 1 & 33 & - & 32 & - & 32 & 30 & - & 29 & 28 & - \\
\hline Braidwood $2 \ldots$ & 32 & - & 31 & - & 29 & - & 28 & 27 & - & 27 \\
\hline Browns Ferry 1 & - & 34 & - & 34 & - & 34 & - & 34 & - & 34 \\
\hline Browns Ferry 2 & 36 & & 35 & - & 35 & - & 35 & - & 34 & \\
\hline Browns Ferry $3 \ldots \ldots \ldots$ & 36 & - & 35 & - & 35 & - & 35 & - & 34 & 33 \\
\hline Brunswick $1 \ldots \ldots$ & 24 & - & 24 & - & 24 & - & 23 & - & 23 & . \\
\hline Brunswick 2 & 26 & . & 25 & - & 25 & - & 25 & - & 25 & - \\
\hline Byron $1 \ldots \ldots \ldots$ & 34 & - & 32 & - & 31 & . & 29 & . & 28 & 28 \\
\hline$\ldots \ldots \ldots \ldots$ & & 36 & - & 34 & 32 & - & 31 & . & 30 & \\
\hline$\ldots \ldots \ldots$ & 36 & 36 & - & 33 & 31 & - & 31 & - & 30 & 30 \\
\hline Calvert Cliffs 1 & - & 31 & - & 30 & - & - & 28 & - & 28 & - \\
\hline Calvert Cliffs 2 & 33 & - & 31 & - & 29 & - & 29 & - & & 27 \\
\hline Catawba $1 \ldots \ldots \ldots$ & 31 & 30 & - & 29 & 29 & - & 27 & 26 & 26 & - \\
\hline$\ldots \ldots \ldots$ & 30 & 31 & - & 29 & 28 & 27 & - & 26 & 26 & - \\
\hline Clinton $1 \ldots \ldots \ldots$ & 32 & - & 33 & 33 & - & 32 & 32 & - & 32 & 31 \\
\hline Comanche Peak $1 \ldots \ldots$ & - & 22 & 21 & 20 & 19 & 19 & 18 & 18 & 18 & 18 \\
\hline Comanche Peak $2 \ldots \ldots$ & - & 24 & 23 & 22 & 22 & & 21 & 21 & 21 & 21 \\
\hline Donald C. Cook $1 \ldots$ & - & 35 & 35 & - & 31 & - & 30 & - & 30 & 29 \\
\hline Donald C. Cook $2 \ldots \ldots$ & 29 & 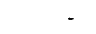 & 28 & - & 26 & - & 25 & 25 & - & 25 \\
\hline Cooper Station . . . . . . . . & 26 & 25 & & 25 & - & 25 & 25 & - & 25 & - \\
\hline Crystal River 3 & - & & 29 & . & - & - & 24 & - & 23 & - \\
\hline Davis-Besse $1 \ldots \ldots \ldots$ & - & 29 & - & 26 & - & - & 31 & - & 31 & - \\
\hline Diablo Canyon $1 \ldots \ldots \ldots$ & - & 37 & - & 35 & 33 & - & 30 & 28 & - & 28 \\
\hline Diablo Canyon 2 & - & 33 & 32 & - & 32 & - & 23 & & 140 & - \\
\hline Dresden $2 \ldots$ & & 24 & & 24 & - & 25 & & 24 & - & 145 \\
\hline$\ldots \ldots \ldots$ & 26 & - & 25 & 25 & - & - & 16 & 16 & - & 15 \\
\hline Duane Arnold & 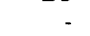 & 16 & 16 & - & 16 & - & 34 & 34 & - & 33 \\
\hline Enrico Fermi $2 \ldots \ldots \ldots$ & 34 & - & 34 & 34 & 34 & $\therefore$ & 24 & & 24 & 24 \\
\hline Joseph M. Farley $1 \ldots \ldots$ & 28 & 27 & & 26 & 25 & 25 & - & 24 & 24 & - \\
\hline Joseph M. Farley $2 \ldots \ldots$ & - & 28 & 27 & - & 25 & - & 34 & - & 34 & - \\
\hline James Fitzpatrick $\ldots \ldots \ldots$ & - & 34 & - & - & 34 & - & 13 & - & 13 & - \\
\hline Fort Calhoun $\ldots \ldots \ldots$ & - & 15 & 14 & - & 13 & 9 & 15 & 42 & - & - \\
\hline$\ldots \ldots \ldots$ & 11 & 10 & 10 & - & 10 & 46 & 45 & - & 45 & - \\
\hline Grand Gulf $1 \ldots \ldots$ & 47 & 46 & - & 45 & & 46 & 45 & - & 45 & - \\
\hline Haddam Neck $\ldots \ldots \ldots$ & 18 & 18 & - & 17 & 15 & 57 & - & - & - & - \\
\hline Shearon Harris $1 \ldots \ldots \ldots$ & - & 27 & 25 & - & 25 & 24 & - & 23 & - & 22 \\
\hline Edwin I. Hatch $1 \ldots \ldots \ldots$ & - & 30 & - & 30 & & 30 & - & 30 & - & 29 \\
\hline Edwin 1. Hatch $2 \ldots \ldots$ & 30 & & 30 & & 30 & & 30 & - & 29 & - \\
\hline Hope Creek $\ldots \ldots \ldots \ldots$ & & 39 & & 39 & 39 & - & 39 & - & 39 & - \\
\hline Indian Point $2 \ldots \ldots \ldots$ & 31 & - & 30 & - & 29 & - & 27 & - & 26 & - \\
\hline Indian Point $3 \ldots \ldots \ldots$ & - & - & 31 & - & - & 29 & - & - & 57 & - \\
\hline$\ldots \ldots \ldots$ & 13 & 13 & 12 & 12 & 12 & 11 & 11 & 11 & 11 & 11 \\
\hline LaSalle City $1 \ldots \ldots \ldots$ & 33 & & 33 & - & 33 & - & 33 & - & 33 & - \\
\hline LaSalle City $2 \ldots \ldots \ldots$ & - & 33 & - & 31 & 32 & 34 & - & 34 & 33 & - \\
\hline Limerick $1 \ldots \ldots$ & 47 & - & - & 45 & - & 44 & - & - & 44 & - \\
\hline$\ldots \ldots \ldots$ & & 34 & - & 34 & - & 48 & - & - & 48 & - \\
\hline Maine Yankee & 45 & - & - & 44 & - & - & 22 & - & 21 & 21 \\
\hline McGuire $1 \ldots \ldots \ldots$ & 49 & - & - & 48 & - & 27 & 26 & - & 26 & 26 \\
\hline$\ldots \ldots \ldots$ & - & 25 & - & 24 & 23 & 27 & 26 & - & 26 & 26 \\
\hline$\ldots \ldots \ldots$ & - & 31 & 29 & 28 & . & - & 29 & - & 103 & - \\
\hline$\ldots \ldots \ldots \ldots$ & 30 & - & 29 & 28 & - & 29 & - & - & 27 & - \\
\hline Millstone 3 & 30 & - & 29 & - & - & 37 & - & 36 & - & 36 \\
\hline Monticello . . . . . . . . . . & - & 31 & - & 30 & - & - & 21 & - & 21 & 83 \\
\hline
\end{tabular}

See footnote at end of table. 
Table D6. Projected Spent Fuel Discharges by U.S. Reactors in the No New Orders Case, 2002-2011 (Continued)

(Metric Tons of Initial Heavy Metal)

\begin{tabular}{|c|c|c|c|c|c|c|c|c|c|c|}
\hline Unit & 2002 & 2003 & 2004 & 2005 & 2006 & 2007 & 2008 & 2009 & 2010 & 2011 \\
\hline Nine Mile Point $1 \ldots \ldots \ldots$ & 29 & - & 28 & - & 28 & - & 28 & 91 & 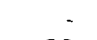 & . \\
\hline Nine Mile Point $2 \ldots \ldots$ & - & 27 & 27 & 27 & - & 27 & 27 & 27 & 26 & - \\
\hline North Anna $1 \ldots \ldots$ & 28 & - & 27 & - & 27 & - & 25 & 24 & - & 24 \\
\hline North Anna $2 \ldots \ldots \ldots$ & 30 & & 29 & & 28 & 27 & & 26 & - & 26 \\
\hline $\begin{array}{l}\text { Oconee } 1 \ldots \ldots \\
\text { Oconee } 2 \ldots \ldots \ldots\end{array}$ & & 26 & & 25 & & 23 & 23 & - & 22 & 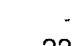 \\
\hline Oconee $2 \ldots \ldots \ldots$ & 26 & - & 25 & - & 24 & 23 & & 23 & - & 22 \\
\hline $\begin{array}{l}\text { Oconee } 3 \ldots \ldots \\
\text { Oyster Creek } 1 \ldots \ldots \ldots\end{array}$ & 29 & 26 & 25 & - & 24 & - & 23 & 22 & - & 22 \\
\hline $\begin{array}{l}\text { Oyster Creek } 1 \ldots \ldots \\
\text { Palisades } \ldots \ldots\end{array}$ & 29 & - & - & 28 & - & 24 & - & 100 & - & \\
\hline $\begin{array}{l}\text { Palisades } \ldots . \\
\text { Palo Verde } 1\end{array}$ & 28 & $\therefore$ & 26 & - & 24 & - & 24 & - & 23 & 82 \\
\hline $\begin{array}{l}\text { Palo Verde } 1 \\
\text { Palo Verde } 2\end{array}$ & & 37 & - & 35 & - & 33 & 32 & - & 32 & - \\
\hline $\begin{array}{l}\text { Palo Verde } 2 \\
\text { Palo Verde } 3\end{array}$ & 37 & 36 & - & 34 & $\cdot$ & 32 & - & 31 & 30 & $\cdot$ \\
\hline $\begin{array}{l}\text { Palo Verde } 3 \\
\text { Peachbottom } 2\end{array}$ & - & 35 & - & 34 & 32 & - & 31 & - & 31 & 30 \\
\hline $\begin{array}{l}\text { Peachbottom } 2 \\
\text { Peachbottom } 3\end{array}$ & 49 & - & - & 47 & - & 47 & & - & 47 & - \\
\hline Peachbottom 3 & & 48 & - & 47 & - & & 47 & & - & 47 \\
\hline$\ldots \ldots$ & 44 & - & 44 & 44 & - & 44 & - & 43 & 43 & - \\
\hline$\ldots \ldots \ldots$ & - & 33 & - & - & 32 & - & - & 32 & - & - \\
\hline Point Beach 1 & 11 & 11 & 11 & 11 & 10 & 10 & - & 10 & 44 & - \\
\hline Point Beach 2 . & 11 & 11 & 11 & 11 & 11 & - & 10 & 10 & 10 & 9 \\
\hline Prairie Island 1 & 17 & 16 & - & 16 & - & 15 & 14 & & 14 & 14 \\
\hline Prairie Island $2 \ldots \ldots \ldots$ & - & 16 & 16 & & 15 & 15 & & 14 & 14 & - \\
\hline Quad Cities $1 \ldots \ldots \ldots$ & 23 & 23 & - & $2: 3$ & 23 & & 23 & 23 & & 20 \\
\hline Quad Cities $2 \ldots$ & 23 & - & 24 & 24 & 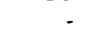 & 23 & 23 & - & 23 & - \\
\hline H.B. Robinson $2 \ldots \ldots$ & 21 & 20 & - & 19 & - & 18 & 17 & 11 & 67 & - \\
\hline River Bend $1 \ldots \ldots \ldots$ & - & 35 & 34 & - & 34 & - & 34 & 34 & - & 34 \\
\hline Salem $1 \quad \ldots \ldots \ldots \ldots$ & 34 & & 33 & - & 33 & - & 30 & - & 29 & - \\
\hline Salem $2 \ldots \ldots \ldots$ & - & 36 & - & - & 34 & - & 32 & - & - & 30 \\
\hline San Onotre 1 & - & 22 & - & - & 21 & 58 & - & & - & - \\
\hline San Onofre 2 & - & 42 & - & 38 & & 36 & - & 35 & - & 35 \\
\hline San Onofre 3 & 41 & - & 40 & - & 38 & & 36 & & 35 & \\
\hline Seabrook 1 . & - & 35 & - & 32 & - & 31 & - & 30 & - & 29 \\
\hline$\ldots \ldots \ldots \ldots$ & - & 29 & - & 27 & - & 26 & - & 25 & - & 24 \\
\hline$\ldots \ldots \ldots \ldots$ & - & 28 & - & 27 & - & 26 & - & 24 & - & 24 \\
\hline South Texas $1 \ldots \ldots \ldots$ & 35 & 34 & - & 32 & - & 30 & - & 30 & 29 & - \\
\hline South Texas $2 \ldots \ldots \ldots$ & - & 36 & 34 & - & 32 & - & 31 & & 30 & - \\
\hline St. Lucie $1 \quad \ldots \ldots \ldots \ldots$ & 27 & 26 & - & 24 & 25 & - & 23 & 22 & - & 22 \\
\hline St. Lucie $2 \ldots \ldots \ldots \ldots$ & - & 27 & 26 & . & 24 & - & 23 & 23 & - & 22 \\
\hline Summer $1 \ldots \ldots$ & - & 29 & 29 & - & 28 & - & 26 & 25 & - & 25 \\
\hline$\ldots \ldots \ldots$ & - & 23 & - & 22 & 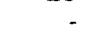 & 20 & - & 20 & 20 & 10 \\
\hline Surry $2 \ldots \ldots \ldots \ldots$ & & 23 & - & 22 & - & 21 & 20 & - & 19 & - \\
\hline Susquehanna $1 \ldots \ldots$ & 35 & & 35 & 34 & - & 35 & 34 & - & 34 & - \\
\hline Susquehanna $2 \ldots \ldots \ldots$ & 36 & 36 & & 35 & & 35 & 36 & - & 35 & - \\
\hline Trojan $\ldots \ldots \ldots \ldots \ldots$ & 24 & 23 & 23 & 23 & 22 & 21 & 21 & . & 20 & 20 \\
\hline Turkey Point $3 \ldots \ldots \ldots$ & - & 19 & - & 18 & 18 & - & 17 & - & 16 & 16 \\
\hline Turkey Point 4 & 19 & 19 & - & 18 & - & 18 & 17 & - & 16 & \\
\hline Vogtle $1 \ldots \ldots$ & 39 & - & - & 37 & - & 34 & - & 33 & - & 33 \\
\hline Vogtle $2 \ldots \ldots \ldots \ldots$ & - & 36 & - & 34 & - & 32 & - & - & 30 & - \\
\hline Vermont Yankee $1 \ldots \ldots$ & 21 & 21 & - & 21 & - & 21 & 21 & - & 21 & 11 \\
\hline Washington Nuclear $2 \ldots$ & 21 & 32 & 20 & 20 & 21 & 21 & 21 & 21 & 20 & 20 \\
\hline Waterford $3 \ldots \ldots \ldots$ & - & 32 & - & 31 & 30 & - & 29 & 28 & & 28 \\
\hline Watts $\operatorname{Bar} 1 \ldots \ldots \ldots$ & 28 & - & 28 & 27 & - & 25 & 24 & . & 24 & 23 \\
\hline Watts Bar $2 \ldots \ldots \ldots$ & - & 27 & - & 27 & 27 & - & 25 & 24 & - & 24 \\
\hline Wolf Creek $1 \ldots \ldots \ldots$ & 35 & 40 & - & 40 & - & - & 30 & - & 30 & - \\
\hline Yankee-Rowe $1 \ldots \ldots \ldots$ & & & & & & - & & - & - & - \\
\hline Zion $1 \ldots \ldots \ldots \ldots$ & - & 33 & 32 & & 29 & - & 28 & 28 & - & 28 \\
\hline Zion $2 \ldots \ldots \ldots \ldots$ & - & 31 & - & 29 & 27 & - & 27 & 27 & - & 26 \\
\hline 3 Mile Island $1 \ldots \ldots$ & - & 33 & - & - & 30 & - & 29 & - & - & 28 \\
\hline BWR Subtotal . . . . . . . & 808 & 536 & 553 & 766 & 517 & 595 & 774 & 543 & 990 & 534 \\
\hline PWR Subtotal $\ldots \ldots \ldots$ & 1,000 & 1,550 & 971 & 1,331 & 1,256 & 1,090 & 1,341 & 964 & 1,303 & 1,125 \\
\hline Total $\ldots \ldots \ldots \ldots$ & 1,809 & 2,186 & 1,523 & 2,097 & 1,773 & 1,685 & 2,116 & 1,507 & 2,292 & 1,659 \\
\hline
\end{tabular}

Source: Projections derived from the International Nuclear Model and Form RW-859, "Nuclear Fuel Data" (1990) 
Table D7. Projected Spent Fuel Discharges by U.S. Reactors in the No New Orders Case, 2012-2021 (Metric Tons of Initial Heavy Metal)

\begin{tabular}{|c|c|c|c|c|c|c|c|c|c|c|}
\hline Unit & 2012 & 2013 & 2014 & 2015 & 2016 & 2017 & 2018 & 2019 & 2020 & 2021 \\
\hline Arkansas Nuclear $1 \ldots \ldots$ & & 24 & 82 & - & - & & - & - & - & - \\
\hline Arkansas Nuclear $2 \ldots \ldots$ & 23 & & 23 & 23 & & 22 & 90 & - & - & - \\
\hline Beaver Valley $1 \ldots \ldots \ldots$ & 25 & & 26 & & 73 & & & & & - \\
\hline Beaver Valley $2 \ldots \ldots$ & - & 25 & & 24 & & 25 & - & 25 & 25 & - \\
\hline Bellefonte $1 \ldots \ldots \ldots$ & 30 & & 31 & & 30 & 30 & - & 30 & & 30 \\
\hline Bellefonte $2 \ldots \ldots \ldots$ & 31 & 31 & - & 30 & - & 30 & - & 30 & 30 & - \\
\hline Big Rock $1 \ldots \ldots \ldots$ & - & - & - & - & - & & - & . & & - \\
\hline Braidwood $1 \ldots \ldots \ldots$ & 28 & & 29 & 28 & - & 28 & 28 & - & 27 & - \\
\hline Braidwood $2 \ldots \ldots \ldots$ & & 27 & & 27 & - & 27 & 26 & - & 27 & - \\
\hline Browns Ferry $1 \ldots \ldots$ & 32 & 139 & - & - & - & . & . & . & - & - \\
\hline Browns Ferry $2 \ldots \ldots \ldots$ & 30 & & 139 & - & - & - & - & - & - & - \\
\hline Browns Ferry $3 \ldots \ldots \ldots$ & & 32 & & - & 139 & - & - & - & - & - \\
\hline Brunswick $1 \ldots \ldots$ & 22 & & 20 & & 105 & - & - & - & - & - \\
\hline Brunswick $2 \ldots \ldots \ldots$ & 24 & 17 & & 105 & - & - & - & - & & - \\
\hline Byron $1 \ldots \ldots \ldots \ldots$ & & 29 & 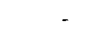 & 28 & & 28 & - & 28 & 27 & - \\
\hline$\ldots \ldots \ldots \ldots$ & 30 & & 30 & & 29 & 29 & - & 29 & - & 29 \\
\hline Callaway $1 \ldots \ldots \ldots$ & & 30 & 30 & & 30 & & 29 & 30 & - & 29 \\
\hline Calvert Clitts $1 \ldots \ldots \ldots$ & 28 & & 28 & 81 & & - & - & - & . & - \\
\hline Calvert Clifts $2 \ldots \ldots \ldots$ & . & 27 & & 27 & 97 & & - & - & - & - \\
\hline Catawba $1 \ldots \ldots \ldots$ & 26 & 26 & & 26 & 25 & 25 & - & 25 & 25 & - \\
\hline Catawba $2 \ldots \ldots \ldots$ & 26 & 26 & 25 & - & 25 & 25 & - & 25 & 25 & 25 \\
\hline Clinton $1 \ldots \ldots \ldots \ldots$ & 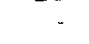 & 30 & 0 & 0 & 29 & 29 & - & 29 & 30 & 0 \\
\hline Comanche Peak $1 \ldots \ldots$ & - & 18 & 18 & 18 & 18 & 18 & 18 & 18 & 18 & 18 \\
\hline Comanche Peak $2 \ldots \ldots$ & - & 21 & 20 & 20 & 20 & & 20 & 20 & 20 & 20 \\
\hline Donald C. Cook $1 \ldots \ldots$ & - & 30 & - & 89 & - & - & - & - & - & - \\
\hline Donald C. Cook $2 \ldots \ldots$ & - & & 25 & & 24 & 24 & 17 & 78 & - & - \\
\hline Cooper Station $\ldots \ldots \ldots$ & - & 21 & - & 100 & - & - & - & - & - & . \\
\hline Crystal River $3 \ldots \ldots \ldots$ & - & 26 & - & - & - & 82 & - & - & - & - \\
\hline Davis-Besse $1 \ldots \ldots \ldots$ & 24 & & 23 & & 13 & 83 & - & - & . & - \\
\hline Diablo Canyon $1 \ldots \ldots$ & 31 & 31 & & 31 & & 30 & & 30 & 29 & - \\
\hline Diablo Canyon $2 \ldots \ldots$ & 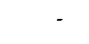 & 28 & 28 & - & 28 & - & 28 & 28 & $\cdot$ & 28 \\
\hline Dresden $2 \ldots \ldots \ldots$ & - & - & & . & - & - & - & - & - & - \\
\hline Dresden $3 \ldots \ldots \ldots$ & - & - & - & - & - & - & - & - & - & - \\
\hline 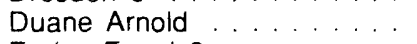 & - & 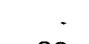 & - & 61 & - & - & - & - & - & - \\
\hline Enrico Fermi $2 \ldots \ldots \ldots$ & - & 32 & & 31 & & 30 & 30 & 31 & - & 31 \\
\hline Joseph M. Farley $1 \ldots \ldots$ & & 24 & 24 & 17 & - & 73 & - & - & - & - \\
\hline Joseph M. Farley $2 \ldots \ldots$ & 24 & - & 24 & 23 & - & 23 & 23 & - & 23 & 73 \\
\hline James Fitzpatrick . . . . . . . & & & 31 & 99 & - & . & . & . & . & - \\
\hline Fort Calhoun $\ldots \ldots \ldots$ & 13 & 56 & - & - & $\cdot$ & $\cdot$ & - & - & - & - \\
\hline Ginna $\ldots \ldots \ldots \ldots$ & & - & - & - & - & - & - & - & - & - \\
\hline Grand Gulf $1 \ldots \ldots \ldots$ & 44 & - & - & 42 & 41 & - & 41 & . & 42 & 43 \\
\hline Haddam Neck . . . . . . . . . & & & - & & & & - & - & & - \\
\hline Shearon Harris $1 \ldots \ldots \ldots$ & 22 & - & 23 & - & 22 & 22 & - & 21 & 21 & - \\
\hline Edwin I. Hatch $1 \ldots \ldots$ & 15 & - & 104 & - & & & - & - & . & . \\
\hline Edwin I. Hatch $2 \ldots \ldots$ & & 28 & - & - & 27 & 21 & 104 & - & - & . \\
\hline Hope Creek . . . . . . . . . & 38 & & - & 36 & 35 & . & 35 & - & 36 & - \\
\hline Indian Point $2 \ldots \ldots \ldots$ & 26 & 87 & - & - & & - & - & - & - & - \\
\hline Indian Point $3 \ldots \ldots \ldots$ & 26 & & - & . & 88 & . & - & . & - & - \\
\hline Kewaunee . . . . . . . . . . & 11 & - & 46 & - & - & - & - & . & - & - \\
\hline LaSalle City $1 \ldots \ldots \ldots$ & 31 & . & & 30 & 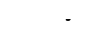 & - & 30 & - & 30 & - \\
\hline LaSalle City $2 \ldots \ldots \ldots$ & 32 & - & - & - & 31 & - & 31 & - & 31 & 28 \\
\hline Limerick $1 \ldots \ldots$ & 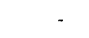 & 42 & - & . & - & 40 & - & - & 40 & - \\
\hline Limerick $2 \ldots \ldots \ldots$ & & 45 & - & - & - & - & 44 & - & & 44 \\
\hline Maine Yankee ........... & 82 & . & . & - & . & - & & - & & - \\
\hline McGuire $1 \ldots \ldots \ldots$ & 26 & - & 25 & 25 & 25 & & 25 & 25 & 24 & 82 \\
\hline McGuire $2 \ldots \ldots$ & 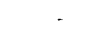 & 26 & 25 & 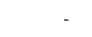 & 25 & 25 & & 25 & 25 & . \\
\hline Millstone $1 \ldots \ldots \ldots$ & - & & & & & & . & - & - & - \\
\hline Millstone $2 \ldots \ldots \ldots$ & 27 & - & 27 & 96 & - & & - & - & - & - \\
\hline Millstone $3 \ldots \ldots$ & & 36 & & 36 & . & 35 & . & 34 & - & 34 \\
\hline Monticello . . . . . . . . . & & & - & - & & - & . & & & - \\
\hline
\end{tabular}

See footnote at end of table. 
Table D7. Projected Spent Fuel Discharges by U.S. Reactors in the No New Orders Case, 2012-2021 (Continued)

(Metric Tons of Initial Heavy Metal)

\begin{tabular}{|c|c|c|c|c|c|c|c|c|c|c|}
\hline Unit & 2012 & 2013 & 2014 & 2015 & 2016 & 2017 & 2018 & 2019 & 2020 & 2021 \\
\hline Nine Mile Point $1 \ldots \ldots \ldots$ & - & - & - & - & - & - & - & - & - & - \\
\hline Nine Mile Point $2 \ldots \ldots \ldots$ & 25 & & 24 & - & 24 & 24 & - & 24 & 25 & 25 \\
\hline North Anna $1 \ldots \ldots$ & - & 24 & & 24 & 18 & - & 73 & - & - & - \\
\hline North Anna $2 \ldots \ldots$ & 26 & & 25 & - & 25 & 25 & - & 21 & 73 & - \\
\hline Oconee $1 \ldots \ldots$ & 22 & 82 & - & - & 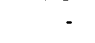 & - & - & - & - & - \\
\hline Oconee $2 \ldots \ldots \ldots \ldots$ & - & 104 & - & - & - & - & - & - & - & - \\
\hline Oconee $3 \ldots \ldots \ldots \ldots$ & - & 22 & 99 & - & . & - & - & - & - & - \\
\hline & - & - & : & : & - & - & - & - & - & - \\
\hline Palisades $\ldots \ldots \ldots \ldots$ & $3 i$ & 32 & - & $3 i$ & - & - & - & - & - & - \\
\hline $\begin{array}{l}\text { Palo Verde } 1 \ldots \ldots \ldots \\
\text { Palo Verde } 2\end{array}$ & $\begin{array}{l}31 \\
30\end{array}$ & 32 & 31 & $\begin{array}{l}31 \\
30\end{array}$ & - & 31 & 30 & - & 30 & - \\
\hline $\begin{array}{l}\text { Palo Verde } 2 \ldots \ldots \ldots \\
\text { Palo Verde } 3\end{array} \ldots \ldots$ & 30 & 31 & 31 & $\begin{array}{l}30 \\
30\end{array}$ & 30 & 30 & 30 & - & 30 & - \\
\hline $\begin{array}{l}\text { Palo Verde } 3 \\
\text { Peachbottom } 2\end{array}$ & $40^{\circ}$ & 31 & 135 & 30 & 30 & - & 29 & . & 29 & 29 \\
\hline $\begin{array}{l}\text { Peachbottom } 2 \\
\text { Peachbottom } 3\end{array}$. $\ldots \ldots$ & 40 & & 135 & . & - & - & - & - & - & - \\
\hline Peachbottom $3 \ldots \ldots \ldots$ & - & 37 & & - & - & - & - & - & - & - \\
\hline Perry $1 \ldots \ldots \ldots \ldots$ & - & - & 41 & 39 & - & 39 & - & 39 & 40 & - \\
\hline Pilgrim 1 . $\ldots \ldots \ldots$ & 103 & - & - & - & - & - & - & - & - & - \\
\hline Point Beach $1 \ldots \ldots \ldots$ & - & - & - & - & - & - & - & - & - & - \\
\hline $\begin{array}{l}\text { Point Beach } 2 \ldots \ldots \ldots \\
\text { Prairie Island } 1\end{array}$ & 44 & & - & - & - & - & - & - & - & - \\
\hline Prairie Island $1 \ldots \ldots \ldots$ & 9 & 43 & & - & - & - & - & - & - & - \\
\hline Prairie Island $2 \ldots \ldots \ldots$ & 14 & 12 & 43 & - & - & - & - & - & - & - \\
\hline Quad Cities $1 \ldots \ldots \ldots$ & 128 & - & - & - & - & - & - & - & - & - \\
\hline Quad Cities $2 \ldots \ldots \ldots$ & 128 & - & - & - & - & - & - & - & - & - \\
\hline H.B. Robinson $2 \ldots \ldots \ldots$ & - & - & - & . & - & - & - & - & - & - \\
\hline River Bend $1 \ldots \ldots \ldots$ & - & - & 32 & - & 31 & 32 & - & 31 & 32 & - \\
\hline Salem $1 \ldots \ldots \ldots$ & 29 & - & 29 & - & 117 & 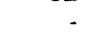 & - & - & - & - \\
\hline Salem $2 \ldots \ldots \ldots$ & - & 31 & . & 30 & - & - & 30 & - & - & 89 \\
\hline San Onotre $1 \ldots \ldots \ldots$ & - & - & - & & - & - & - & - & - & - \\
\hline San Onofre $2 \ldots \ldots \ldots$ & - & 36 & - & 35 & - & 35 & - & 34 & - & 34 \\
\hline San Onofre $3 \ldots \ldots \ldots$ & 35 & & 35 & & 34 & & 34 & & 35 & 35 \\
\hline Seabrook $1 \ldots \ldots \ldots$ & - & 30 & & 29 & & 29 & - & 29 & - & 29 \\
\hline Sequoyah $1 \ldots \ldots \ldots$ & - & - & 24 & - & 24 & 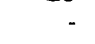 & 24 & . & 89 & - \\
\hline Sequoyah $2 \ldots \ldots \ldots$ & - & 24 & & - & 23 & - & 23 & & 23 & 108 \\
\hline South Texas $1 \ldots \ldots \ldots$ & 30 & - & 29 & - & 29 & 29 & - & 28 & - & 28 \\
\hline South Texas $2 \ldots \ldots \ldots$ & 30 & - & 31 & 30 & & 30 & - & 30 & - & 30 \\
\hline St. Lucie $1 \quad \ldots \ldots \ldots$ & 22 & - & 22 & - & 22 & 22 & - & 22 & 21 & - \\
\hline St. Lucie $2 \ldots \ldots \ldots$ & 22 & - & 22 & - & 22 & 22 & - & 22 & 21 & - \\
\hline Summer $1 \ldots \ldots \ldots$ & - & 26 & 25 & - & 25 & - & 25 & 25 & . & 24 \\
\hline Surry $1 \ldots \ldots \ldots \ldots$ & - & 72 & - & - & - & - & - & - & - & - \\
\hline Surry $2 \ldots \ldots \ldots \ldots$ & 19 & 72 & - & - & - & - & - & - & - & - \\
\hline Susquehanna $1 \ldots \ldots \ldots$ & 33 & . & - & 32 & 31 & - & 32 & 31 & 32 & - \\
\hline Susquehanna $2 \ldots \ldots \ldots$ & 34 & - & - & 33 & 32 & - & 32 & 32 & - & 33 \\
\hline Three Mile island $1 \ldots \ldots$ & - & 29 & 82 & - & & - & - & - & - & - \\
\hline $\operatorname{Trojan} \ldots \ldots \ldots \ldots \ldots$ & 20 & 20 & 31 & 90 & - & - & - & - & - & - \\
\hline Turkey Point $3 \ldots \ldots \ldots$ & 72 & - & - & - & - & - & - & - & - & - \\
\hline Turkey Point $4 \ldots \ldots \ldots$ & 16 & 72 & - & . & - & - & - & - & - & - \\
\hline Vogtle $1 \ldots \ldots \ldots \ldots$ & - & . & 33 & - & 32 & - & 32 & & 32 & - \\
\hline Vogtle $2 \ldots \ldots \ldots \ldots$ & 30 & - & 30 & - & - & 29 & - & 29 & - & 29 \\
\hline Vermont Yankee $1 \ldots \ldots$ & 66 & - & - & - & & & & & & - \\
\hline Washington Nuclear $2 \ldots$ & - & 19 & - & 19 & 19 & 19 & 19 & 19 & 19 & 20 \\
\hline Wateriord $3 \ldots \ldots \ldots$ & 28 & - & 28 & 28 & - & 28 & 27 & - & 27 & 27 \\
\hline Watts Bar 1 & - & 24 & - & 24 & 23 & & 23 & 23 & & 23 \\
\hline Watts Bar 2 & 24 & . & 23 & - & 23 & 23 & 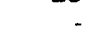 & 23 & 23 & \\
\hline WNP $3 \ldots$ & 37 & - & 37 & - & 37 & - & - & 37 & 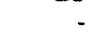 & 37 \\
\hline Wolf Creek $1 \ldots \ldots$ & 30 & . & 30 & - & 29 & 29 & - & 29 & - & 29 \\
\hline Yankee-Rowe $1 \ldots \ldots \ldots$ & - & - & - & - & - & - & - & - & - & - \\
\hline Zion $1 \ldots \ldots \ldots \ldots$ & - & 116 & - & - & - & - & - & - & - & - \\
\hline Zion 2 & - & 115 & - & - & - & - & - & - & - & - \\
\hline $\begin{array}{l}\text { BWR Subtotal } \ldots \ldots \ldots \\
\text { PWR Subtotal } \ldots \ldots\end{array}$ & $\begin{array}{r}845 \\
1,252\end{array}$ & $\begin{array}{r}420 \\
1,597\end{array}$ & $\begin{array}{r}821 \\
1,297\end{array}$ & $\begin{array}{r}466 \\
1,071\end{array}$ & $\begin{array}{r}544 \\
1,145\end{array}$ & $\begin{array}{r}234 \\
1,015\end{array}$ & $\begin{array}{l}397 \\
745\end{array}$ & $\begin{array}{l}237 \\
752\end{array}$ & $\begin{array}{l}358 \\
755\end{array}$ & $\begin{array}{l}225 \\
919\end{array}$ \\
\hline Total ............... & 2,097 & 2,017 & 2,118 & 1,538 & 1,690 & 1,249 & 1,143 & 989 & 1,113 & 1,143 \\
\hline
\end{tabular}

Source: Projections derived from the International Nuclear Model and Form RW-859, "Nuclear Fuel Data" (1990). 
Table D8. Projected Spent Fuel Discharges by U.S. Reactors in the No New Orders Case, 2022-2031 (Metric Tons of Initial Heavy Metal)

\begin{tabular}{|c|c|c|c|c|c|c|c|c|c|c|}
\hline Unit & 2022 & 2023 & 2024 & 2025 & 2026 & 2027 & 2028 & 2029 & 2030 & 2031 \\
\hline Arkansas Nuclear $1 \ldots \ldots$ & - & - & - & - & - & - & - & - & - & - \\
\hline Arkansas Nuclear $2 \ldots \ldots$ & - & - & - & - & - & - & - & - & - & - \\
\hline $\begin{array}{l}\text { Beaver Valley } 1 \ldots \ldots \ldots \\
\text { Beaver Valley } 2 \ldots \ldots \ldots\end{array}$ & - & - & - & - & - & - & - & - & - & - \\
\hline $\begin{array}{l}\text { Beaver Valley } 2 \ldots \ldots \ldots \\
\text { Bellefonte } 1 \ldots \ldots\end{array}$ & 25 & - & 25 & 17 & - & 72 & - & - & - & 5 \\
\hline $\begin{array}{l}\text { Bellefonte } 1 \\
\text { Bellefonte } 2 \ldots \ldots \ldots\end{array}$ & - & 31 & 31 & - & 31 & 33 & - & 35 & - & 32 \\
\hline $\begin{array}{l}\text { Bellefonte } 2 \ldots \ldots \ldots \ldots \\
\text { Big Rock } 1 \ldots \ldots \ldots\end{array}$ & 30 & - & 30 & 30 & - & 30 & $\cdot$ & 30 & 30 & - \\
\hline $\begin{array}{l}\text { Big Rock } 1 \ldots \ldots \ldots \ldots \\
\text { Braidwood } 1 \ldots \ldots \ldots\end{array}$ & & - & - & - & - & - & - & - & - & - \\
\hline $\begin{array}{l}\text { Braidwood } 1 \ldots \ldots \ldots \ldots \\
\text { Braidwood } 2 \ldots \ldots \ldots \ldots\end{array}$ & 28 & 29 & - & 28 & 28 & 82 & - & - & - & - \\
\hline $\begin{array}{l}\text { Braidwood } 2 \ldots \ldots \ldots \ldots \\
\text { Browns Ferry } 1 \ldots \ldots \ldots \ldots\end{array}$ & 27 & - & 27 & 27 & - & 28 & 82 & - & - & - \\
\hline $\begin{array}{l}\text { Browns Ferry } 1 \ldots \ldots \ldots \ldots \\
\text { Browns Ferry } 2 \ldots \ldots \ldots \ldots\end{array}$ & - & - & - & - & - & - & - & - & $\cdot$ & - \\
\hline $\begin{array}{l}\text { Browns Ferry } 2 \ldots \ldots \ldots \\
\text { Browns Ferry } 3 \ldots \ldots \ldots\end{array}$ & $\cdot$ & $\cdot$ & - & - & - & $\cdot$ & - & - & $\cdot$ & - \\
\hline $\begin{array}{l}\text { Browns Ferry } 3 \ldots \ldots \ldots \ldots \\
\text { Brunswick } 1 \ldots \ldots \ldots\end{array}$ & - & - & $\dot{-}$ & - & - & - & - & 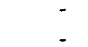 & - & - \\
\hline Brunswick $2 \ldots \ldots \ldots$ & - & - & - & - & 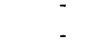 & i. & . & - & - & - \\
\hline Byron $1 \ldots \ldots \ldots \ldots$ & 29 & & - & 82 & - & - & - & - & . & - \\
\hline Byron $2 \ldots \ldots \ldots \ldots$ & - & 30 & 30 & - & - & 82 & - & - & - & - \\
\hline $\begin{array}{l}\text { Callaway } 1 \\
\text { Calvert Cliffs } 1\end{array}$ & 30 & - & 82 & - & - & - & - & - & - & - \\
\hline Calvert Cliffs 1 & - & - & - & - & - & - & $\cdot$ & $\cdot$ & - & - \\
\hline Calvert Clifts $2 \ldots \ldots \ldots$ & - & - & - & - & - & - & - & - & - & - \\
\hline $\begin{array}{l}\text { Catawba } 1 \ldots \ldots \ldots \\
\text { Catawba } 2 \ldots \ldots \ldots\end{array}$ & 25 & 26 & - & 81 & - & - & - & - & - & - \\
\hline Catawba $2 \ldots \ldots \ldots$ & - & 25 & 25 & - & 82 & - & - & - & - & - \\
\hline $\begin{array}{l}\text { Clinton } 1 \text { Peak } 1 \ldots \ldots \ldots \\
\text { Comanche Pea }\end{array}$ & 30 & 29 & - & 33 & - & 116 & & - & - & - \\
\hline $\begin{array}{l}\text { Comanche Peak } 1 \ldots \ldots \ldots \\
\text { Comanche Peak } 2 \ldots \ldots\end{array}$ & 18 & 18 & 18 & 19 & - & 19 & 20 & 21 & 78 & - \\
\hline $\begin{array}{l}\text { Comanche Peak } 2 \ldots \ldots \ldots \\
\text { Donald C. Cook } 1 \ldots \ldots\end{array}$ & - & 20 & 20 & 20 & 20 & 20 & 20 & - & 20 & 20 \\
\hline $\begin{array}{l}\text { Donald C. Cook } 1, \ldots \ldots \ldots \\
\text { Donald C. Cook } 2 \ldots \ldots\end{array}$ & - & - & - & - & - & - & - & - & - & - \\
\hline $\begin{array}{l}\text { Donald C. Cook } 2 \ldots \ldots \ldots \\
\text { Cooper Station } \ldots \ldots \ldots\end{array}$ & - & - & - & - & - & - & - & - & - & - \\
\hline $\begin{array}{l}\text { Cooper Station } \ldots \ldots \ldots \ldots \\
\text { Crystal River } 3 \ldots \ldots \ldots \ldots\end{array}$ & - & - & - & - & - & - & - & - & - & - \\
\hline $\begin{array}{l}\text { Crystal River } 3 . \\
\text { Davis-Besse } 1 .\end{array}$ & - & - & - & - & - & - & - & - & - & - \\
\hline $\begin{array}{l}\text { Davis-Besse } 1 \\
\text { Diablo Canyon } 1\end{array}$ & - & - & - & - & - & - & - & - & - & - \\
\hline $\begin{array}{l}\text { Diablo Canyon } 1 \ldots \ldots \ldots \\
\text { Diablo Canyon } 2 \ldots \ldots\end{array}$ & 30 & - & 110 & - & - & - & - & - & - & - \\
\hline Diablo Canyon $2 \ldots \ldots$ & 29 & - & 28 & 82 & - & - & - & - & - & - \\
\hline Dresden $2 \ldots \ldots \ldots \ldots$ & - & - & - & - & - & - & - & - & - & - \\
\hline Dresden $3 \ldots \ldots \ldots$ & - & - & - & - & - & - & - & - & - & - \\
\hline Duane Arnold $\ldots \ldots \ldots \ldots$ & - & - & - & - & - & - & - & - & - & - \\
\hline Enrico Fermi $2 \ldots \ldots \ldots$ & 32 & 33 & - & 139 & - & - & - & - & - & - \\
\hline Joseph M. Farley $1 \ldots \ldots$ & - & - & - & $\cdot$ & - & - & - & - & - & - \\
\hline Joseph M. Farley $2 \ldots \ldots$ & - & - & - & - & - & - & - & - & - & - \\
\hline James Fitzpatrick . . . . . . . & - & - & - & - & - & - & - & - & - & - \\
\hline Fort Calhoun $\ldots \ldots \ldots$ & - & - & - & - & $\cdot$ & - & $\cdot$ & $\cdot$ & - & - \\
\hline Ginna $\ldots \ldots \ldots \ldots$ & - & - & - & - & - & - & - & - & - & - \\
\hline Grand Gulf $1 \ldots \ldots$ & - & 42 & 141 & - & - & - & - & - & - & - \\
\hline Haddam Neck ......... . . & - & & & - & - & - & - & - & - & - \\
\hline Shearon Harris $1 \ldots \ldots \ldots$ & 22 & - & 23 & 22 & - & 73 & - & - & - & - \\
\hline Edwin I. Hatch $1 \ldots \ldots$ & - & - & - & - & - & - & - & - & - & - \\
\hline Edwin I. Hatch $2 \ldots \ldots$ & - & - & - & - & - & - & - & - & - & - \\
\hline Hope Creek . . . . . . . . . . & 37 & 36 & - & 41 & 142 & - & - & - & - & - \\
\hline Indian Point $2 \ldots \ldots$ & - & $\cdot$ & - & - & - & - & - & - & - & - \\
\hline Indian Point $3 \ldots \ldots \ldots$ & - & - & - & - & - & - & - & - & - & - \\
\hline Kewaunee $\ldots \ldots \ldots \ldots$ & - & - & - & - & - & - & - & - & - & - \\
\hline LaSalle City $1 \ldots \ldots$ & 139 & - & - & $\cdot$ & - & $\cdot$ & $\cdot$ & - & - & \\
\hline LaSalle City $2 \ldots \ldots \ldots$ & - & - & 139 & - & - & - & - & - & - & - \\
\hline Limerick $1 \ldots \ldots \ldots$ & 42 & - & 27 & 135 & - & - & - & - & - & - \\
\hline Limerick $2 \ldots \ldots$ & - & 46 & - & - & 47 & - & 50 & 135 & - & - \\
\hline Maine Yankee ......... . & - & - & - & - & - & - & - & - & - & - \\
\hline McGuire $1 \ldots \ldots \ldots$ & - & - & - & - & - & - & - & - & $\cdot$ & - \\
\hline$\ldots \ldots \ldots \ldots$ & 26 & 100 & - & - & - & - & - & - & - & - \\
\hline Millstone $1 \ldots \ldots \ldots$ & 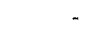 & - & - & - & - & - & - & - & - & - \\
\hline Millstone $2 \ldots \ldots \ldots$ & - & - & - & - & - & - & - & - & - & - \\
\hline Millstone $3 \ldots \ldots \ldots$ & - & 36 & - & 34 & 89 & - & - & - & - & - \\
\hline Monticello . . . . . . . . . . . . & - & - & - & - & & - & - & - & - & - \\
\hline
\end{tabular}

See footnote at end of table. 
Table D8. Projected Spent Fuel Discharges by U.S. Reactors in the No New Orders Case, 2022-2031 (Continued)

(Metric Tons of Initial Heavy Metal)

\begin{tabular}{|c|c|c|c|c|c|c|c|c|c|c|}
\hline Unit & 2022 & 2023 & 2024 & 2025 & 2026 & 2027 & 2028 & 2029 & 2030 & 2031 \\
\hline Nine Mile Point $1 \ldots \ldots$ & - & - & $\therefore$ & - & $\cdot$ & - & - & - & - & - \\
\hline Nine Mile Point $2 \ldots \ldots$ & 25 & - & 25 & 28 & 26 & 147 & - & . & - & - \\
\hline North Anna $1 \ldots \ldots$ & 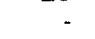 & - & 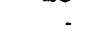 & - & - & - & - & . & - & - \\
\hline North Anna $2 \ldots \ldots$ & - & . & - & - & - & - & - & - & - & - \\
\hline Oconee $1 \ldots \ldots \ldots$ & - & - & - & - & - & - & - & - & - & - \\
\hline$\ldots \ldots \ldots$ & - & - & - & - & - & . & - & . & - & - \\
\hline Oconee $3 \ldots \ldots$ & - & - & . & - & . & - & . & - & . & - \\
\hline Oyster Creek $1 \ldots \ldots \ldots$ & - & - & - & - & - & . & - & - & - & . \\
\hline Palisades . . . . . . . & - & - & - & - & - & . & . & - & - & - \\
\hline Palo Verde $1 \ldots \ldots$ & 30 & 30 & 23 & 97 & - & - & - & - & - & - \\
\hline Palo Verde 2 & 31 & 31 & - & 27 & 99 & - & - & - & - & - \\
\hline Palo Verde $3 \ldots \ldots \ldots$ & - & 29 & - & 30 & 28 & 97 & - & . & - & - \\
\hline Peachbottom $2 \ldots \ldots \ldots$ & - & - & - & - & - & . & - & - & . & - \\
\hline Peachbottom 3 & - & - & - & - & - & - & - & . & - & \\
\hline$\ldots \ldots \ldots$ & 41 & 43 & - & 45 & 133 & - & . & . & - & - \\
\hline$\ldots \ldots \ldots$ & - & - & - & - & - & - & - & . & - & - \\
\hline Point Beach 1 & - & - & - & - & - & - & - & - & - & - \\
\hline Point Beach $2 \ldots \ldots$ & - & - & - & - & - & - & - & - & - & - \\
\hline Prairie Island $1 \ldots \ldots \ldots$ & - & - & - & - & - & - & . & . & - & - \\
\hline Prairie Island $2 \ldots \ldots$ & - & - & - & - & - & - & - & - & - & - \\
\hline Quad Cities $1 \ldots \ldots$ & - & - & - & - & - & - & - & - & - & . \\
\hline Quad Cities $2 \ldots \ldots \ldots$ & - & - & . & - & - & - & - & - & - & - \\
\hline H.B. Robinson $2 \ldots \ldots$ & - & - & - & - & - & - & - & - & - & - \\
\hline River Bend $1 \ldots \ldots \ldots$ & 32 & 33 & - & 143 & - & . & - & - & - & - \\
\hline Salem $1 \quad \ldots \ldots \ldots \ldots$ & - & - & - & - & - & - & - & . & - & - \\
\hline Salem $2 \ldots \ldots \ldots$ & - & - & - & - & - & - & - & - & - & - \\
\hline San Onofre $1 \ldots \ldots$ & - & - & - & - & - & - & - & . & - & - \\
\hline San Onotre $2 \ldots \ldots \ldots$ & 106 & - & - & - & - & - & . & . & - & - \\
\hline San Onotre $3 \ldots \ldots$ & . & 107 & . & - & - & - & - & . & - & - \\
\hline Seabrook $1 \ldots \ldots \ldots$ & - & 30 & 30 & - & 31 & - & 33 & - & 89 & - \\
\hline Sequoyah $1 \ldots \ldots \ldots$ & - & - & - & - & - & - & - & - & - & . \\
\hline Sequoyah $2 \ldots \ldots \ldots$ & - & - & - & - & - & - & - & - & . & - \\
\hline South Texas 1 & 28 & - & 29 & & 29 & 29 & 119 & - & - & . \\
\hline South Texas $2 \ldots \ldots \ldots$ & & 31 & 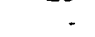 & 30 & 32 & 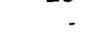 & - & 104 & - & . \\
\hline St. Lucie $1 \quad \ldots \ldots \ldots$ & & - & . & - & - & - & - & . & - & - \\
\hline St. Lucie $2 \ldots \ldots \ldots$ & 21 & 84 & - & - & - & - & - & - & - & . \\
\hline Summer $1 \ldots \ldots \ldots$ & 93 & - & - & - & - & - & - & - & - & - \\
\hline Surry $1 \ldots \ldots \ldots \ldots$ & - & - & . & . & - & . & - & - & - & . \\
\hline Surry $2 \ldots \ldots \ldots \ldots$ & - & - & - & . & - & - & - & - & - & . \\
\hline Susquehanna $1 \ldots \ldots$ & 132 & & - & - & - & - & - & - & . & . \\
\hline Susquehanna $2 \ldots \ldots$ & 33 & 22 & 132 & - & - & - & - & - & . & . \\
\hline Three Mile Island $1 \ldots \ldots$ & - & - & . & - & - & . & - & . & - & . \\
\hline Trojan $\ldots \ldots \ldots \ldots$ & - & - & - & - & - & - & - & - & . & - \\
\hline Turkey Point $3 \ldots \ldots$ & - & - & - & - & - & - & - & - & - & . \\
\hline Turkey Point 4 & - & - & - & - & - & - & - & - & - & . \\
\hline$\ldots \ldots \ldots \ldots$ & 33 & - & . & 33 & - & 124 & . & - & . & . \\
\hline Vogtle $2 \ldots \ldots \ldots$ & 30 & 30 & - & 30 & - & 27 & . & 89 & . & . \\
\hline Vermont Yankee $1 \ldots$ & - & - & - & - & - & . & . & - & - & . \\
\hline Washington Nuclear $2 \ldots$ & . & - & 135 & - & - & - & - & - & . & . \\
\hline Waterford $3 \ldots \ldots$ & & 27 & 18 & 91 & - & - & - & - & - & . \\
\hline Watts Bar $1 \ldots \ldots \ldots$ & 24 & - & 24 & 24 & - & 25 & 26 & 26 & - & 24 \\
\hline Watts Bar $2 \ldots \ldots$ & 23 & 23 & . & 23 & 23 & . & 23 & 23 & 23 & \\
\hline WNP $3 \ldots \ldots$ & & 37 & - & 37 & & 37 & . & 37 & . & 37 \\
\hline Wolf Creek $1 \ldots \ldots$ & - & 30 & . & 90 & . & - & . & . & - & . \\
\hline Yankee-Rowe $1 \ldots \ldots$ & - & - & - & - & - & - & - & - & - &. \\
\hline Zion $1 \ldots \ldots \ldots$ & - & - & - & - & - & . & - & - & - & . \\
\hline Zion $2 \ldots \ldots \ldots$ & - & - & - & - & - & - & - & - & - & . \\
\hline BWR Subtotal . . . . . . . & 543 & 284 & 599 & 564 & 348 & 262 & 50 & 135 & - & - \\
\hline PWR Subtotal . . . . . . . & 708 & 807 & 571 & 953 & 492 & 777 & 323 & 365 & 240 & 113 \\
\hline Total . . . . . . . . & 1251 & 1091 & 1170 & 1516 & 839 & 1039 & 373 & 500 & 240 & 113 \\
\hline
\end{tabular}

Source: Projections derived from the International Nuclear Model and Form RW-859, "Nuclear Fuel Data" (1990). 
Table D9. Projected Spent Fuel Discharges by U.S. Reactors in the No New Orders Case, 2032-2040 (Metric Tons of Initial Heavy Metal)

\begin{tabular}{llllllllllll}
\hline Unit & 2032 & 2033 & 2034 & 2035 & 2036 & 2037 & 2038 & 2039 & 2040 & \\
\hline
\end{tabular}

Arkansas Nuclear 1

Arkansas Nuclear 2

Beaver Valley 1

Beaver Valley 2

Bellefonte 1

$2 \ldots \ldots$

Bellefonte 2

Big Rock 1

Braidwood 1

Braidwood 2

Browns Ferry 1

Browns Ferry 2

Browns Ferry 3

Brunswick 1

Brunswick 2

Byron 1

Byron 2

Callaway 1

Calvert Cliffs 1

Calvert Clifts 2

Catawba 1

Catawba 2

Clinton 1

Comanche Peak

Comanche Peak 2

Donald C. Cook 1

Donald C. Cook 2

Cooper Station

Crystal River 3

Davis-Besse 1

Diablo Canyon 1

Diablo Canyon 2

Dresden 2

Dresden 3

Duane Arnold

Enrico Fermi 2

Joseph $M$. Farley 1

Joseph M. Farley 2

James Fitzpatrick

Fort Calhoun

Ginna

Grand Gulf 1

Haddam Neck

Shearon Harris 1

Edwin I. Hatch 1

Edwin 1. Hatch 2

Hope Creek

Indian Point 2

Indian Point 3

Kewaunee

LaSalle City 1

LaSalle City 2

Limerick 1

Limerick 2

Maine Yankee

McGuire 1

McGuire 2

Millstone 1

Millstone 2

Millstone 3

Monticello

See footnote at end of table. 
Table D9. Projected Spent Fuel Discharges by U.S. Reactors in the No New Orders Case, 2032-2040 (Continued)

(Metric Tons of Initial Heavy Metal)

\begin{tabular}{|c|c|c|c|c|c|c|c|c|c|}
\hline Unit & 2032 & 2033 & 2034 & 2035 & 2036 & 2037 & 2038 & 2039 & 2040 \\
\hline Nine Mile Point $1 \ldots \ldots \ldots$ & . & - & . & - & . & . & . & . & - \\
\hline Nine Mile Point $2 \ldots \ldots$ & - & - & . & - & - & - & - & - & - \\
\hline North Anna $1 \ldots \ldots$ & $\cdot$ & $\cdot$ & $\cdot$ & $\cdot$ & $\cdot$ & $\cdot$ & $\cdot$ & $\cdot$ & $\cdot$ \\
\hline North Anna $2 \ldots \ldots$ & - & - & - & - & $\cdot$ & - & - & - & - \\
\hline Oconee $1 \ldots \ldots \ldots$ & $\cdot$ & - & - & - & - & - & - & - & - \\
\hline Oconee $2 \ldots \ldots \ldots \ldots$ & - & - & - & - & - & - & - & - & - \\
\hline Oconee $3 \ldots \ldots \ldots$ & - & - & - & - & - & - & - & . & - \\
\hline Oyster Creek $1 \ldots \ldots \ldots$ & - & - & - & - & - & - & $\cdot$ & - & - \\
\hline Palisades .............. & - & - & - & - & - & - & - & - & - \\
\hline Palo Verde $1 \ldots \ldots \ldots$ & - & - & . & - & - & - & - & - & - \\
\hline Palo Verde $2 \ldots \ldots \ldots$ & - & $\cdot$ & - & - & - & - & - & - & - \\
\hline Palo Verde $3 \ldots \ldots \ldots$ & - & - & - & - & - & - & - & . & - \\
\hline Peachbottom $2 \ldots \ldots \ldots$ & - & - & - & - & - & - & - & - & - \\
\hline Peachbottom $3 \ldots \ldots$ & - & - & - & - & - & - & - & - & - \\
\hline Perry $1 \ldots \ldots \ldots \ldots$ & - & - & - & - & - & - & - & - & - \\
\hline Pilgrim $1 \ldots \ldots \ldots$ & - & - & . & - & - & . & - & - & - \\
\hline Point Beach $1 \ldots \ldots \ldots$ & - & - & - & - & - & - & $\cdot$ & - & - \\
\hline Point Beach $2 \ldots \ldots \ldots$ & - & - & - & - & - & - & - & - & - \\
\hline Prairie Island $1 \ldots \ldots \ldots$ & - & - & - & - & - & - & - & - & - \\
\hline Prairie Island $2 \ldots \ldots \ldots$ & - & - & - & - & $\cdot$ & $\cdot$ & - & - & - \\
\hline Quad Cities $1 \ldots \ldots \ldots$ & - & . & - & - & - & . & - & - & - \\
\hline Quad Cities $2 \ldots \ldots \ldots$ & - & - & $\cdot$ & - & $\cdot$ & - & - & - & $\cdot$ \\
\hline H.B. Robinson $2 \ldots \ldots \ldots$ & - & - & - & - & . & . & - & - & - \\
\hline River Bend $1 \ldots \ldots \ldots$ & - & - & - & - & - & - & - & $\cdot$ & - \\
\hline Salem $1 \quad \ldots \ldots \ldots \ldots$ & - & - & - & $\cdot$ & $\cdot$ & - & $\cdot$ & - & $\cdot$ \\
\hline Salem $2 \ldots \ldots \ldots$ & $\cdot$ & - & - & - & - & - & - & $\cdot$ & - \\
\hline San Onotre $1 \ldots \ldots \ldots$ & - & - & $\cdot$ & - & - & $\cdot$ & - & $\cdot$ & $\cdot$ \\
\hline San Onotre $2 \ldots \ldots \ldots$ & . & - & - & - & - & - & - & - & - \\
\hline San Onofre $3 \ldots \ldots$ & - & - & - & - & - & - & - & $\cdot$ & - \\
\hline Seabrook $1 \ldots \ldots \ldots$ & - & - & - & $\cdot$ & $\cdot$ & $\cdot$ & - & - & $\cdot$ \\
\hline Sequoyah $1 \ldots \ldots \ldots$ & - & - & - & - & - & - & - & - & - \\
\hline Sequoyah $2 \ldots \ldots \ldots$ & - & - & - & - & $\cdot$ & - & - & - & - \\
\hline South Texas $1 \ldots \ldots \ldots$ & - & - & - & - & - & - & - & - & - \\
\hline South Texas $2 \ldots \ldots \ldots$ & $\cdot$ & - & - & - & $\cdot$ & $\cdot$ & - & - & - \\
\hline St. Lucie $1 \quad \ldots \ldots \ldots \ldots$ & - & - & - & - & . & - & - & - & - \\
\hline St. Lucie $2 \ldots \ldots \ldots \ldots$ & . & - & - & - & - & - & - & $\cdot$ & - \\
\hline Summer $1 \ldots \ldots \ldots$ & - & - & - & - & - & - & - & - & - \\
\hline Surry $1 \ldots \ldots \ldots$ & - & - & - & - & - & - & - & - & - \\
\hline Surry $2 \ldots \ldots \ldots$ & . & - & - & - & $\cdot$ & - & - & - & - \\
\hline Susquehanna $1 \ldots \ldots \ldots$ & - & - & - & - & - & - & - & - & - \\
\hline Susquehanna $2 \ldots \ldots \ldots$ & - & - & - & . & - & - & - & - & - \\
\hline Three Mile Island $1 \ldots \ldots \ldots$ & - & - & - & - & - & - & - & - & - \\
\hline 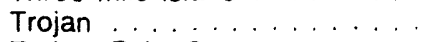 & - & - & - & - & - & - & - & - & - \\
\hline Turkey Point $3 \ldots \ldots \ldots$ & - & - & - & - & - & - & - & - & - \\
\hline Turkey Point $4 \ldots \ldots \ldots$ & - & - & - & - & - & - & - & - & - \\
\hline Vogtle $1 \quad \ldots \ldots \ldots \ldots$ & - & - & - & - & - & - & - & - & - \\
\hline Vogtle $2 \ldots \ldots \ldots \ldots$ & - & - & - & - & - & - & - & - & - \\
\hline Vermont Yankee $1 \ldots \ldots$ & - & - & - & - & - & - & . & - & - \\
\hline Washington Nuclear $2 \ldots \ldots$ & - & - & - & - & $\cdot$ & - & - & - & - \\
\hline Waterford $3 \ldots \ldots$ & - & - & - & - & - & - & - & - & - \\
\hline Watts $B a r 1 \ldots \ldots \ldots$ & 89 & - & - & - & - & - & - & - & - \\
\hline Watts Bar $2 \ldots \ldots \ldots$ & 23 & 27 & - & 89 & . & - & - & - & - \\
\hline WNP $3 \ldots \ldots \ldots$ & - & 37 & - & 37 & - & 37 & - & - & 108 \\
\hline Wolf Creek $1 \ldots \ldots \ldots$ & - & - & - & - & - & - & - & - & - \\
\hline Yankee-Rowe $1 \ldots \ldots \ldots$ & - & - & - & - & - & - & - & - & - \\
\hline Zion $1 \ldots \ldots \ldots \ldots$ & - & $\cdot$ & $\cdot$ & - & - & - & - & - & $\cdot$ \\
\hline Zion $2 \ldots \ldots \ldots \ldots$ & $\cdot$ & - & - & - & - & $\cdot$ & - & $\cdot$ & - \\
\hline BWR Subtotal $\ldots \ldots \ldots \ldots$ & - & - & - & - & - & - & - & - & - \\
\hline PWR Subtotal . . . . . . . . & 193 & 142 & 64 & 126 & 58 & - & 186 & 18 & 108 \\
\hline Total . . . . . . . . . . . . & 193 & 142 & 64 & 126 & 58 & - & 186 & 18 & 108 \\
\hline
\end{tabular}

Source: Projections derived from the International Nuclear Model and Form RW-859, "Nuclear Fuel Data" (1990). 


\section{Appendix E}

Projected Uranium Requirements in Metric Tons Uranium 


\section{Appendix E}

\section{Projected Uranium Requirements in Metric Tons Uranium}

Table E1. Projected Average Annual Uranium Requirements for Nuclear Power Plants in the Free Market Economies, 1991-2010

(Thousand Metric Tons of Uranium)

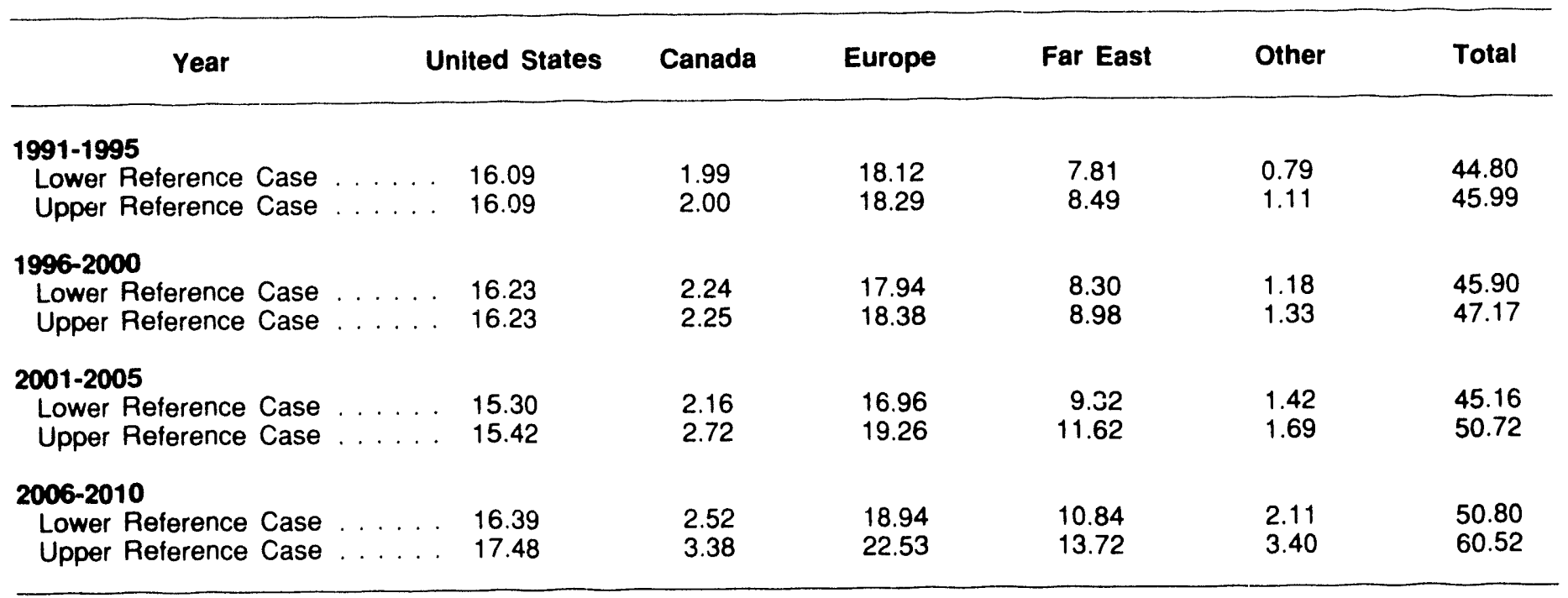

Note: Totals may not equal sum of components due to independent rounding.

Source: Projected uranium requirements calculated using the International Nuclear Model, based on capacity projections from Energy Information Administration, Commercial Nuclear Power 1991: Prospects for the United States and the World, DOE/EIA-0438(91) (Washington, DC, August 1991). 
Table E2. Projected Cumulative Uranium Requirements for Nuclear Power Plants in the Free Market Economies, 1991-2010

(Thousand Metric Tons of Uranium)

\begin{tabular}{|c|c|c|c|c|c|c|}
\hline \multicolumn{7}{|l|}{$1991-1995$} \\
\hline Lower Reference Case & 80.47 & 9.96 & 90.58 & 39.00 & 3.96 & 223.98 \\
\hline Upper Reference Case & 80.47 & 10.00 & 91.47 & 42.46 & 5.54 & 229.94 \\
\hline \multicolumn{7}{|l|}{$1996-2000$} \\
\hline \multicolumn{7}{|l|}{$2001-2005$} \\
\hline Lower Reference Case & . . 238.13 & 31.96 & 265.06 & 127.09 & 17.00 & 679.24 \\
\hline Upper Reference Case & 238.75 & 34.89 & 279.64 & 145.47 & 20.66 & 719.40 \\
\hline \multicolumn{7}{|l|}{$2006-2010$} \\
\hline
\end{tabular}




\section{Glossary}

Boiling-Water Reactor (BWR): A light-water reactor in which water, used as both coolant and moderator, is allowed to boil in the core. The resulting steam can be used directly to drive a turbine.

Breeder Reactor: A reactor that both produces and consumes fissionable fuel, especiaily one that creates more fuel than it consumes. The new fissionable material is created by a process known as breeding, in which neutrons from fission are captured in fertile materials.

Burnup: A measure of the amolint of energy obtained from fuel in a reactor. Typically, burnup is expressed as the amount of energy produced per unit weight of fuel irradiated or "burned." Burnup levels are generally measured in units of megawattdays thermal per metric ton of initial heavy metal (MWDT/ MTIHM).

Canadian Deuterium-Uranium Reactor (CANDU): Uses heavy water or deuterium oxide $(D, O)$, rather than light water $\left(\mathrm{H}_{2} \mathrm{O}\right)$ as the coolant and moderator. Deuterium is an isotope of hydrogen that has a different neutron absorption spectrum from that of ordinary hydrogen. In a deuterium-oxide-moderated reactor, fuel made from natural uranium (0.71 U-235) can sustain a chain reaction.

Capacity: The load for which a generating unit is rated, either by the user or by the manufacturer. In this report, "capacity" refers to the utility's design electrical rating (see below).

Capacity Factor: The ratio of the electricity produced by a generating unit, for the period of time considered, to the energy that could have been produced at continuous full-power operation during the same period.

Commercial Operation: The phase of reactor operation that begins when power ascension ends and the operating utility formally declares the nuclear power plant to be available for the regular production of electricity. This declaration is usually related to the satisfactory completion of qualification tests on critical components of the unit.

Construction Pipeline: The various stages involved in the acquisition of a nuclear reactor by a utility. The events that define these stages are the ordering of a reactor, the licensing process, and the physical construction of the nuclear generating unit. A reactor is said to be "in the pipeline" when the reactor is ordered and "out of the pipeline" when it completes low-power testing and begins operation toward full power. (See Operable).

Design Electrical Rating (capacity), Net: The nominal net electrical output of a nuclear unit, as specified by the utility for the purpose of plant design.

Discharged Fuel: Irradiated fuel removed from a reactor during refueling. (See Spent Fuel.)

Enrichment Tails Assay: A measure of the amount of fissile uranium (U-235) remaining in the waste stream from the uranium enrichment process. The natural uranium "feed" that enters the enrichment process generally contains 0.711 percent (by weight) U-235. The "product stream" contains enriched uranium (greater than 0.711 percent U-235) and the "waste" or "tails" stream contains depleted uranium (less than 0.711 percent $U-235)$. At the historical enrichment tails assay of 0.2 percent, the waste stream would contain 0.2 percent $U-235$. A higher enrichment tails assay requires more uranium feed (thus permitting natural uranium stockpiles to be decreased), while increasing the output of enriched material for the same energy expenditure.

Equilibrium Cycle: An analytıcal term which refers to fuel cycles that occur after the initial one or two cycles of a reactor's operation. For a given reactor, equilibrium cycles have similar fuel characteristics.

Fast Breeder Reactor (FBR): A reactor in which the fission chain reaction is sustained primarily by fast neutrons rather than by thermal or intermediate neutrons. Fast reactors require little or no moderator to slow down the neutrons from the speeds at which they are ejected from fissioning nuclei. This type of reactor produces more fissile material than it consumes.

Fertile Material: Material that is not itself fissionable by thermal neutrons but can be converted to fissile material by irradiation. The two principal fertile materials are uranium-238 and thorium-232.

Fissile Material: Material that can be catused to undergo atomic fission when bombarded by neutrons. The most important fissionable materials are uranium-235, plutonium-239, and uranium-233. 
Fission: The proress whereby an atomic nucleus of appropriate type, after capturing a neutron, splits into (generally) two nucisi of lighter elements, with the release of substantial imounts of energy and two or more neutrons.

FME: Free Market Econo nies. Countries that are members of the Council for Mutual Economic Assistance (CMEA) are not included.

Forward Costs: The operating and capital costs (in current dollars) still to be incurred in the production of uranium from estimated reserves; such costs are used in assigning the uranium reserves to cost categories. Forward costs include labor, materials, power and fuel, royalties, payroll and production taxes, insurance, and general and administrative costs. Expenditures prior to reserve estimates-e.g., for property acquisition, exploration, mine development, and mill construction-are excluded from forward cost determinations. Income taxes, profit, and the cost of money are alsc excluded. Thus, forward costs are neither the full costs of production nor the market price at which the uranium will be cold.

Full Power Day: The equivalent of 24 hours of full power operation by a reactor. The number of full power days in a specific cycle is the product of the reactor's capacity factor and the length of the cycle.

Gas-Cooled Fast Breeder Reactor (GCBR): A fast breeder reactor that is cocled by a gas (usually helium) under pressure.

Generation (Electricity): The process of producing electric energy from other forms of energy; also, the amount of electric energy produced, expressied in watthours (Wh).

Gross Generation: The total amount of electric energy produced by the generating units at a generating station or stations, measured at the generator terminals.

Net Generation: Gross generation less the electric energy consumed at the generating station for station use.

Gigawatt-Electric (GWe): One billion watts of electric capacity.

Heavy Water: Water containing a significantly greater proportion of heavy hydrogen (deuterium) atoms to ordinary hydrogen atoms than is found in ordinary (light) water. Heavy water is used as a moderator in some seactors because it slows neltrons effectively and also has a low cross-section for absorption of neutrons.
Heavy-Water-Moderated Reactor: A reactor that uses heavy water as its moderator. Heavy water is an excellent moderator and thus permits the use of inexpensive natural (unenriched) uranium as fuel.

Kilowatt-Electric (kWe): One thousand watts of electric capacity.

Kilowatthour (kWh): One thousand watthours.

Light Water: Ordinary water $\left(\mathrm{H}_{2} \mathrm{O}\right)$, as distinguished from heavy water or deuterium oxide $\left(\mathrm{D}_{2} \mathrm{O}\right)$.

Light-Water Reactor (LWR): A nuclear reactor that uses water as the primary coolant and moderator, with slightly enriched uranium as fuel. There are two types of commercial light-water reactor-the boilingwater reactor (BWR) and the pressurized-water reactor (PWR).

Liquid Metal Fast Breeder Reactor (LMFBR): A nuclear breeder reactor, cooled by molten sodium, in which fission is caused by fast neutrons.

Low-Power Testing: The period of time between a plant's initial fuel loading date and the issuance of its operating (full power) license. The maximum level of operation during this period is 5 percent of the unit's design electrical rating.

Megawatt-Electric (MWe): One million watts of electric capacity.

Megawatthour (MWh): One million watthours of electric energy.

Moderator. A material such as ordinary water, heavy water, or graphite, used in a reactor to slow down high-velocity neutrons, thus increasing the likelihood of further fission.

Net Summer Capability: The steady hourly output which generating equipment is expected to supply to system load exclusive of auxiliary power as demonstrated by testing at the time of summer peak demand.

Nuclear Power Plant: single- or multi-unit facility in which heat produced in a reactor by the fissioning of nuclear fuel is used to drive a steam turbine(s).

Nuclear Reactor: An apparatus in which the nuclear fission chain can be initiated, maintained, and controlled so that energy is released at a specific rate. The reactor apparatus includes fissionable material (fuel) such as uranium or plutonium; fe.tile material; moderating material (unless it is a fast reactor); a heavy-walled pressure vessel; shielding to protect 
personnel; provision for heat removal; and control elements and instrumentation.

Plutonium (Pu): A heavy, fissionable, radioactive, metallic element (atomic number 94). Plutonium occurs in nature in trace amounts. It can also be produced as a byproduct of the fission reaction in a uranium-fueled nuclear reactor and can be recovered for future use.

Power Ascension: The period of time between a plant's initial fuel loading date and its date of first commercial operation (including the low-power testing period). Plants in the first operating cycle (the time from initial fuel loading to the first refueling), which lasts approximately 2 years, operate at an average capacity factor of about 40 percent.

Pressurized-Water Reactor (PWR): A nuclear reactor in which heat is transferred from the core to a heat exchanger via water kept under high pressure, so that high temperatures can be maintained in the primary system without boiling the water. Steam is generated in a secondary circuit.

Reasonably Assured Resources (RAR): Resilurce category that refers to uranium that occurs in known mineral deposits of such size, grade, and configuration that it could be recovered within the given production cost ranges, with currently proven mining and processing technology. Estimates of tonnage and grade are based on specific sample data and measurements of the deposits and on knowledge of deposit characteristics. The RAR category corresponds to the U.S. Department of Energy (DOE) Reserves category.

Reinserted Fuel: Irradiated fuel that is discharged in one cycle and inserted in the same reactor during a subsequent refueling. In a few cases, fuel discharged from one reactor has been sised to fuel a different reactor.

Separative Work Unit (SWU): The standard measure of enrichment services. The effort expended in separating a mass $F$ of feed of assay $x_{t}$ into a mass $P$ of product of assay $x_{1}$ and waste of mass $W$ and assay $x_{w}$ is expressed in terms of the number of separative work units needed, given by the expression $S W U=W V\left(x_{w}\right)+P V\left(x_{p}\right)-F V\left(x_{1}\right)$, where $V(x)$ is the "value function," defined as $V(x)=(1-2 x) \ln [(1-x) / x]$.

Spent Fuel: Irradiated fuel that is permanently discharged from a reactor at the end of a fuel cycle. Except for possible reprocessing, this fuel must eventually be removed from its temporary storage location at the reactor site and placed in a permanent repository. Spent fuel is typically measured either in metric tons of heavy metal (i.e., only the heavy metal content of the spent fuel is considered) or in metric tons of initial heavy metal (essentially, the initial mass of the uranium before irradiation). The difference between these two quantities is the weight of the fission products.

Terawatthour (TWh): One trillion $\left(10^{12}\right)$ watthours of electric energy.

Uranium (U): A heavy, naturally radioactive, metallic element (atomic number 92). Its two principally occurring isotopes are uranium-235 and uranium-238. Uranium-235 is indispensable to the nuclear industry, because it is the only isotope existing in nature, to any appreciable extent, that is fissionable by thermal neutrons. Uranium-238 is also important, because it absorbs neutrons to produce a radioactive isotope that subsequently decays to plutonium-239, an isotope that also is fissionable by thermal neutrons. 


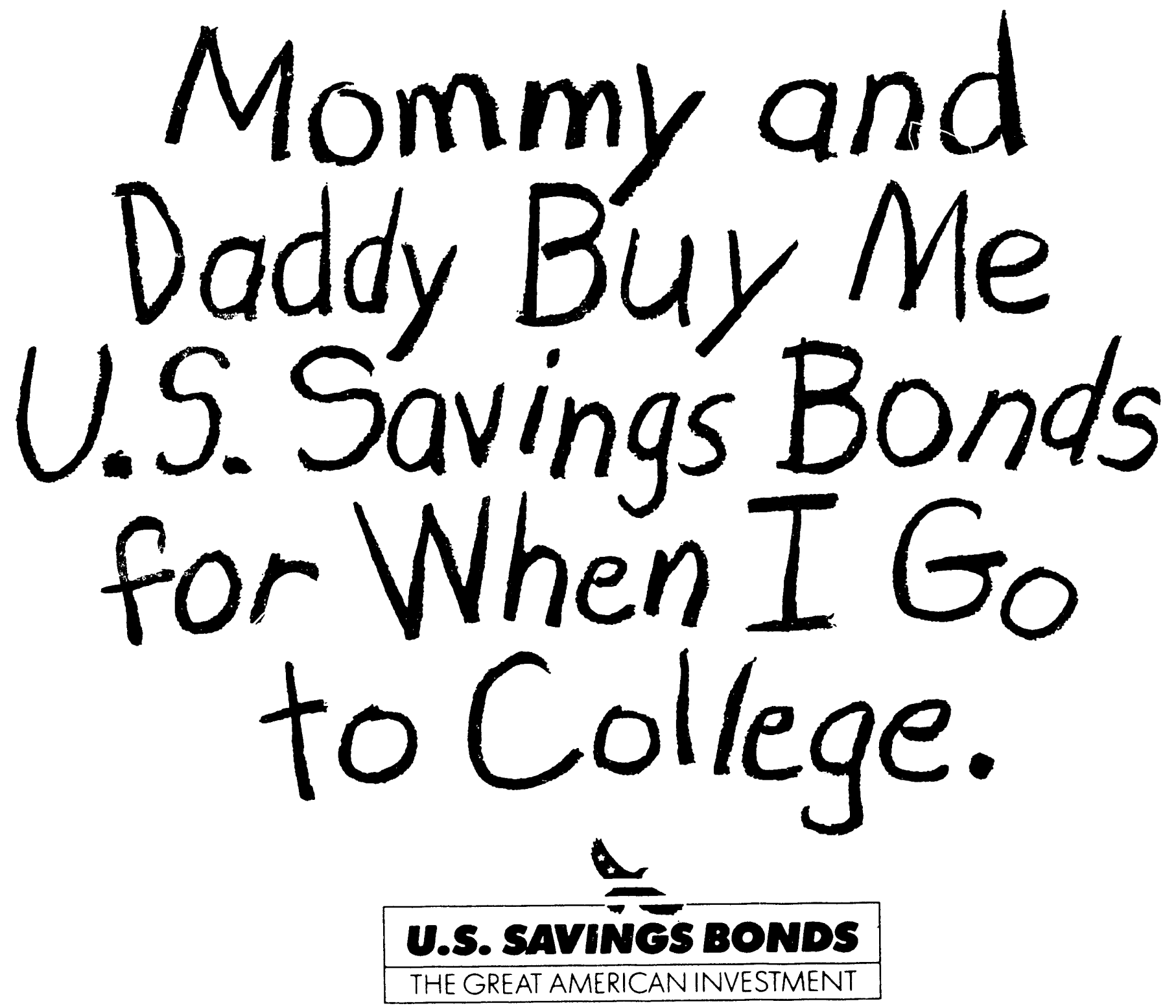

Now tax free for education. It's smarter than ever to start saving today! 


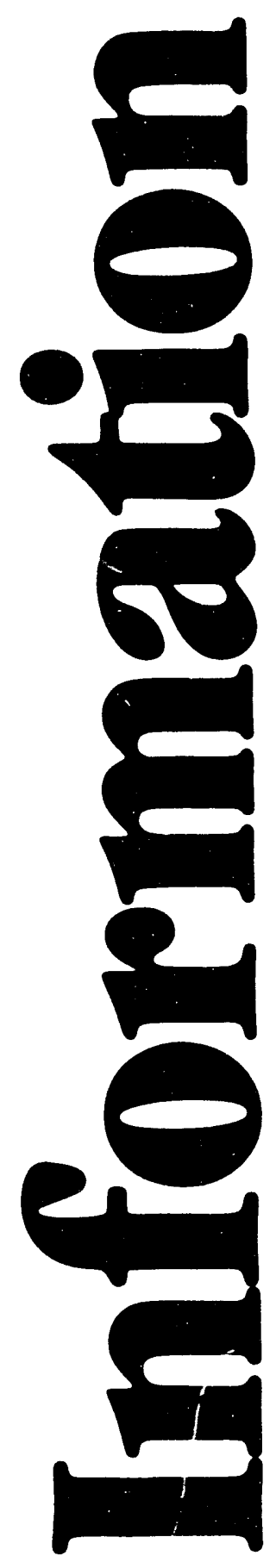

Information from the Federal Government on subjects ranging from agriculture to zoology is available at Depository Libraries across the nation.

You can visit these libraries and use the Depository collections without charge.

To find one in your area, contact your local library or write: Federal Depository Library Program, Office of the Public Printer, Washington, DC 20401.

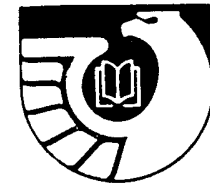

\section{Federal Depository Library Program}



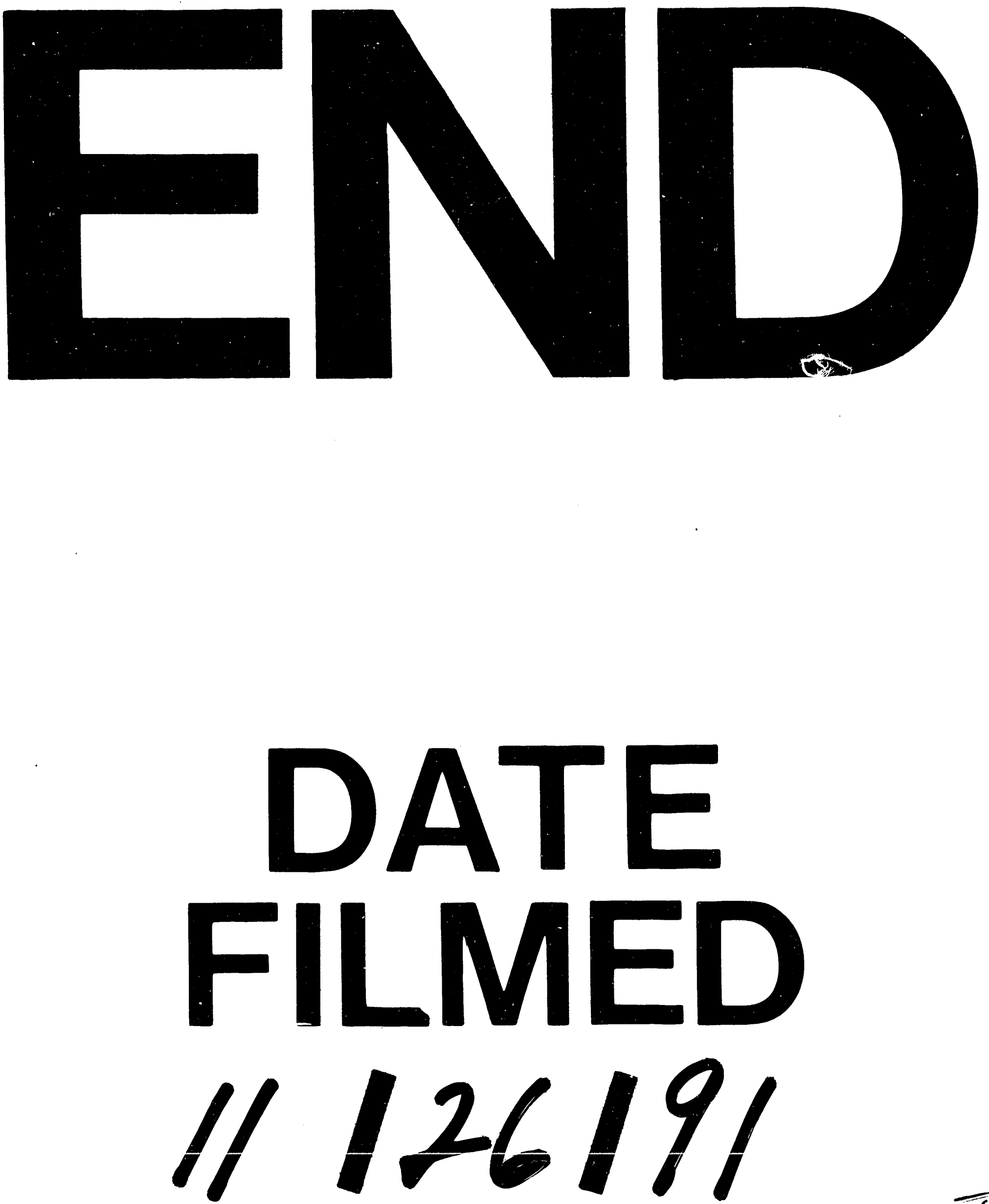
